Florida International University FIU Digital Commons

5-14-1998

\title{
Beliefs of Icelandic elderly living in the greater Reykjavik area toward autonomy and paternalism in caregiving of the elderly
}

Ingibjorg Svava Asgeirsdottir

Florida International University

DOI: $10.25148 /$ etd.FI14032355

Follow this and additional works at: https://digitalcommons.fiu.edu/etd

Part of the Occupational Therapy Commons

\section{Recommended Citation}

Asgeirsdottir, Ingibjorg Svava, "Beliefs of Icelandic elderly living in the greater Reykjavik area toward autonomy and paternalism in caregiving of the elderly" (1998). FIU Electronic Theses and Dissertations. 1320.

https://digitalcommons.fiu.edu/etd/1320 
FLORIDA INTERNATIONAL UNIVERSITY

Miami, Florida

BELIEFS OF ICELANDIC ELDERLY

LIVING IN THE GREATER REYKJAVÍK AREA

TOWARD AUTONOMY AND PATERNALISM

IN

CAREGIVING OF THE ELDERLY

A thesis submitted in partial satisfaction of the

requirements for the degree of

MASTER OF SCIENCE

IN

OCCUPATIONAL THERAPY

By

Ingibjörg Svava Ásgeirsdóttir 
To: Dr. DeLois P. Weeks

College of Health Sciences

This thesis, written by Ingibjörg Svava Ásgeirsdóttir, and entitled Beliefs of Icelandic Elderly Living in the Greater Reykjavík Area Toward Autonomy and Paternalism in Caregiving of the Elderly, having been approved in respect to style and intellectual content, is referred to you for judgement.

We have read this thesis and recommended that it be approved.

Pamela Shaffner

Paulette Johnson /

Gail Ann Hills, Major Professor

Date of Defense: May 14, 1998.

This thesis of Ingibjörg Svava Ásgeirsdóttir is approved.

Dr. DeLors P. Weeks

Dean, College of Health Sciences

Dr. Richard L. Campbell

Dean of Graduate Studies

Florida International University, 1998 
To my mother Guðrún F. Magnúsdóttir and the memory of my father Ásgeir Ásgeirsson. 


\section{ACKNOWLEDGEMENTS}

I wish to thank the members of my committee for their guidance, recommendations and support. Gail, Paulette and Pamela, thank you for helping me reach this goal.

A special thank you goes to you Gail, for being my mentor and for sharing your experience and time with me. You have been a tremendous support from the beginning to the end of my long-distance learning. No one but you could have achieved what you did. You will always be remembered for what you did for the promotion of Icelandic occupational therapy.

I also want to thank the librarians at the Reykjavík University Teaching Hospital who always assisted me with a smile. And I thank my superiors for having confidence in me, and my co-workers for their patient understanding and support. I am especially grateful to the staff and the elders at the senior housing and senior citizen centers at Aflagrandi, Grandavegur and Vitatorg in Reykjavik, for their participation in this study. They made this study come true.

One more thank you goes to my friends for their support. And another to the six Icelandic occupational therapists, my fellow students, who also ventured this long-distance study with me. My thanks to you for the time we spent together, "good times and bad" all worth remembering, and a special thank you for your encouragement, friendship and support.

And last but not least, I must thank my mother and my family for their love, and for believing in me and remaining supportive throughout my endeavor. And most of all, thank you all for always reminding me that I could do it! 


\section{ABSTRACT OF THE THESIS \\ BELIEFS OF ICELANDIC ELDERLY \\ LIVING IN THE GREATER REYKJAVIK AREA \\ TOWARD AUTONOMY AND PATERNALISM \\ IN CAREGIVING OF THE ELDERLY}

By

Ingibjörg Svava Ásgeirsdóttir

Florida International University, 1998

Miami, Florida

Gail Ann Hills, Major Professor

With the aging population and the increase in health care costs, issues of independence and autonomy will have a greater impact on formal and informal health care. Changes in occupational functioning that accompany increased age has raised the demand for family assistance to the elderly. It is important for occupational therapists to understand the elderly's perceptions toward autonomy and paternalism in caregiving of the elderly because it is assumed that attitudes and beliefs affect how people interact and care for the elderly.

A convenience sample of 57 Icelandic elderly were surveyed regarding their attitudes toward autonomy and paternalism in caregiving of the elderly. Results indicated that Icelandic elderly held strong beliefs toward autonomy but were undecided toward paternalism. Significant differences were found between groups. Elderly living at home indicated stronger beliefs on both autonomy and paternalism compared to those living in senior housing complexes. Elderly women held stronger beliefs in autonomy in contrast to the males, who were more paternalistic, and married subjects held stronger beliefs than did single respondents. 


\section{TABLE OF CONTENTS}

LIST OF TABLES ix

CHAPTER I

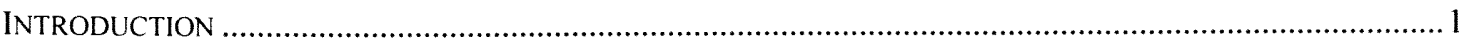

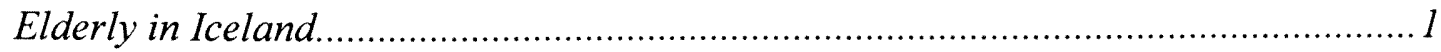

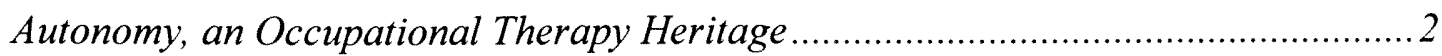

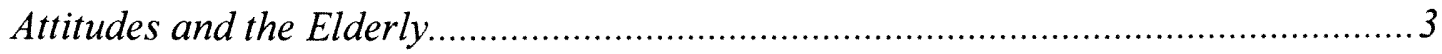

Occupational Therapy in Home Health Care ............................................................5

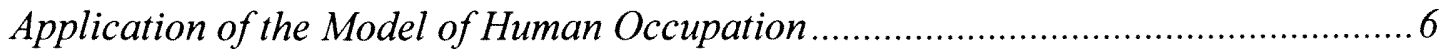

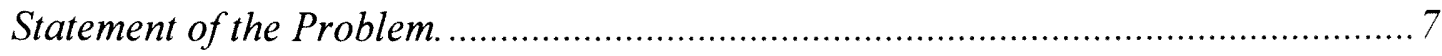

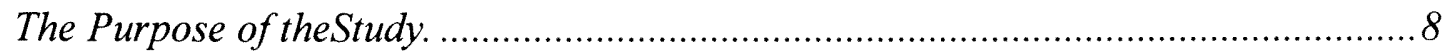

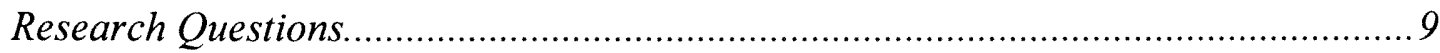

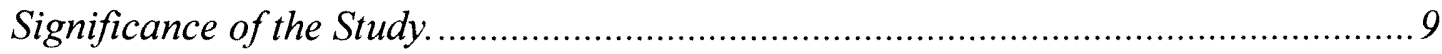

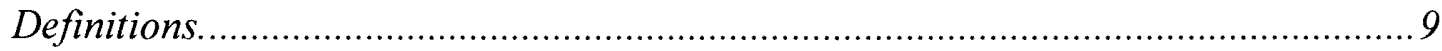

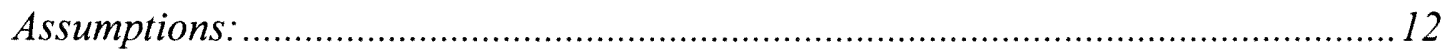

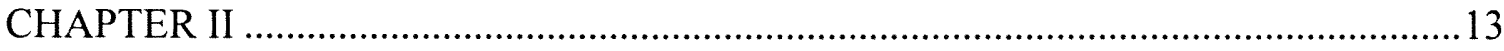

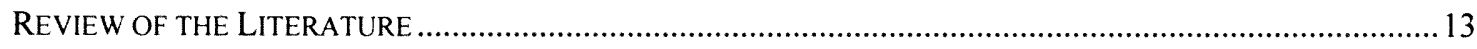

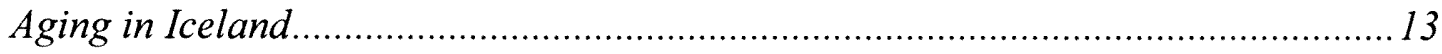

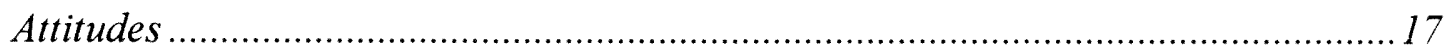

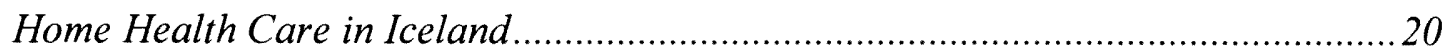

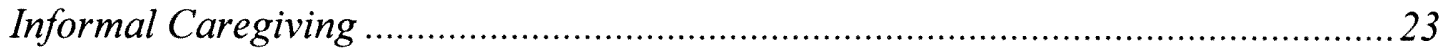

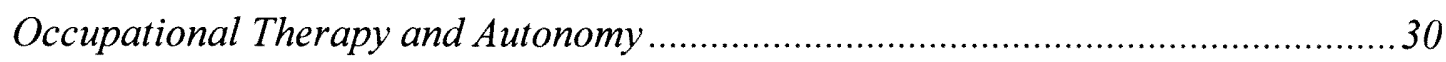

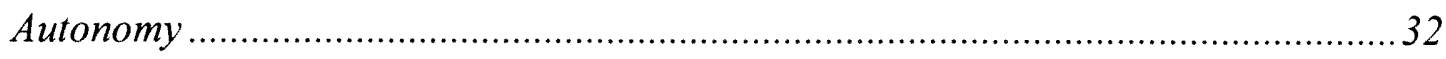

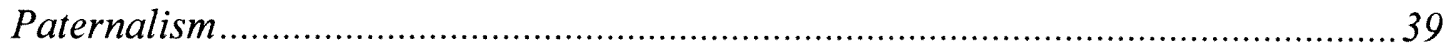

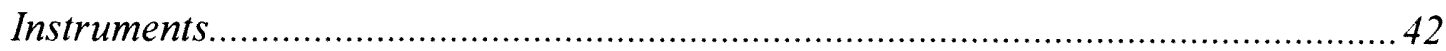

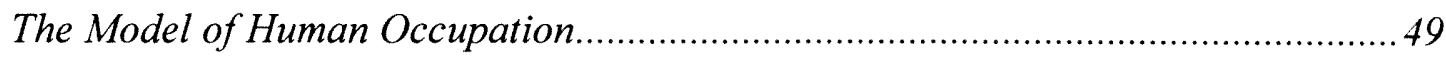

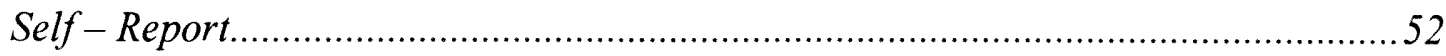




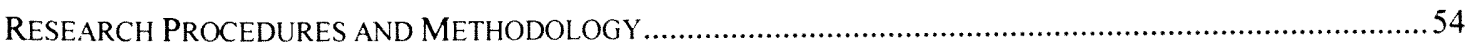

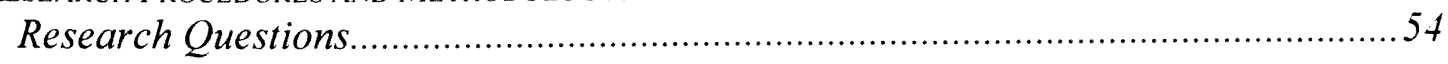

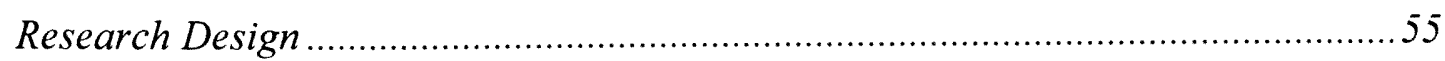

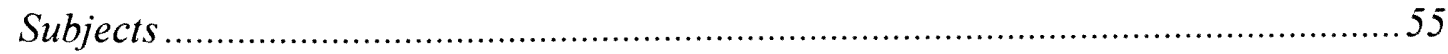

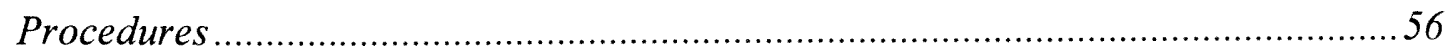

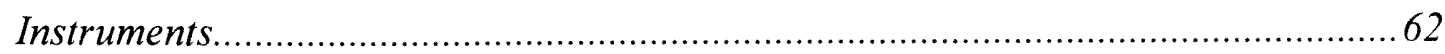

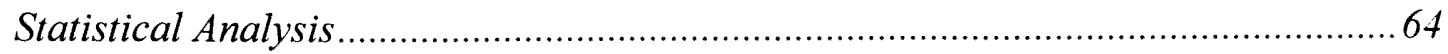

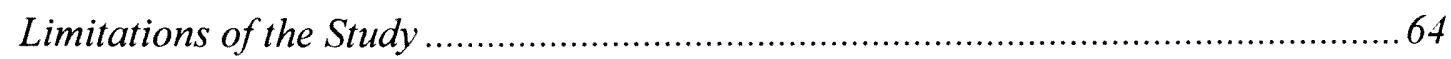

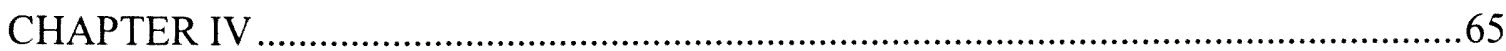

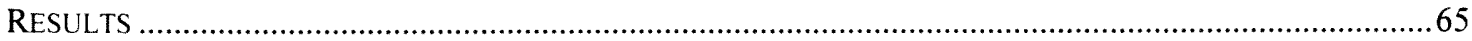

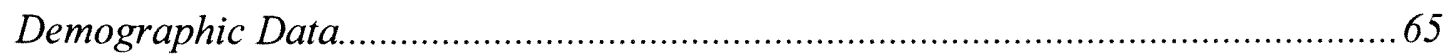

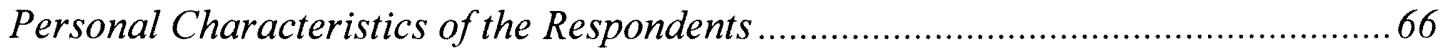

The Respect for Autonomy Scale and the Paternalism Scale Scores........................74

Reliability for the Autonomy and Paternalism Scale .............................................. 78

Differences in Scores Between Two Groups of Community Living Elderly .............. 81

Significant Differences in Characteristics of Respondents by Housing .....................82

Differences in Beliefs Toward Autonomy and Paternalism ......................................8 87

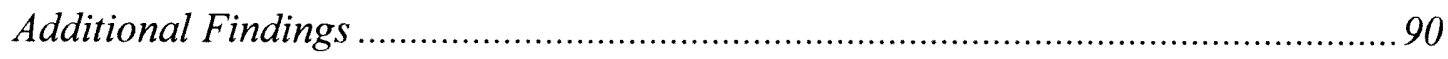

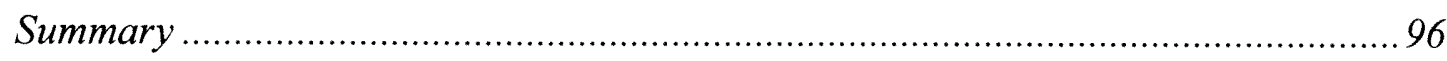

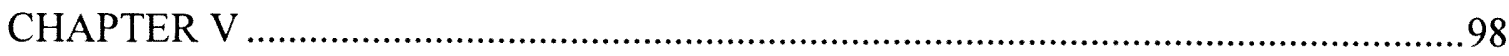

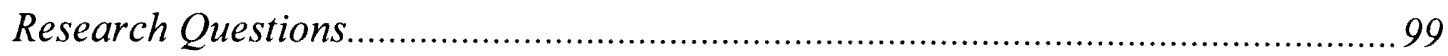

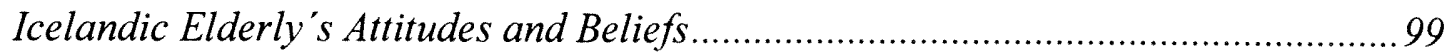

Differences in Beliefs Between Two Groups of Community Living Elderly ............. 102

Variables that Affect Autonomous and Paternalistic Beliefs of the Respondents.... 104

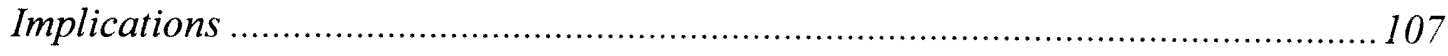

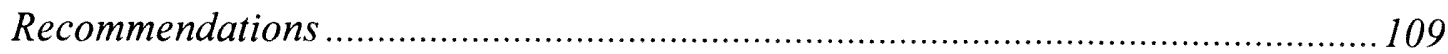

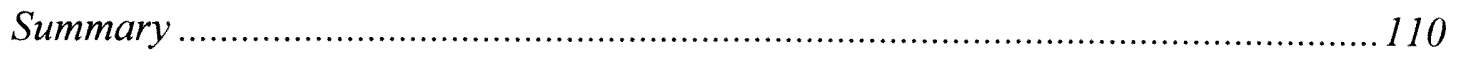

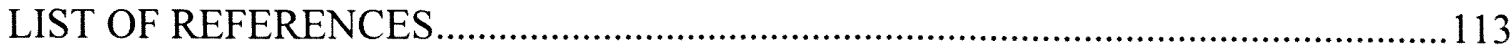




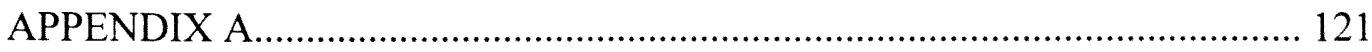

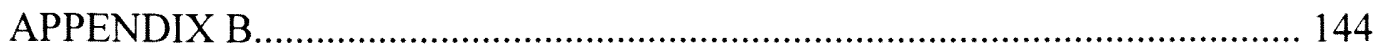

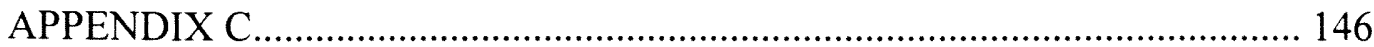

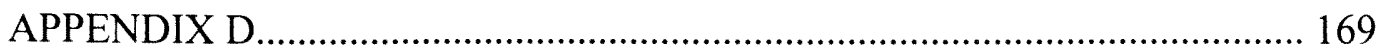

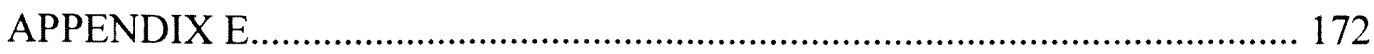


Table 1: Personal Characteristics of the Respondents.............................................66

Table 2: Personal Characteristics of the Adult Children.............................................73

Table 3: $\quad$ Respect for Autonomy Scale Scores for Icelandic Elderly ............................75

Table 4: $\quad$ Paternalism Scale Scores for Icelandic Elderly ..........................................

Table 5: Reliability for the Respect for Autonomy and Paternalism Scales...............79

Table 6: Reliability for Autonomy and Paternalism in Caregiving Situations...........80

Table 7: Differences in Characteristics of Respondents by Housing.........................82

Table 8: Significant Differences in Characteristics of Respondents..........................83

Table 9: Beliefs Toward Autonomy and Paternalism by Type of Housing................84

Table 10: Caregiving and Beliefs Toward Autonomy and Paternalism

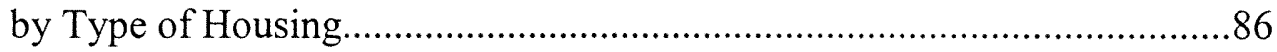

Table 11: Differences in Beliefs Toward Autonomy by Type of Housing....................88

Table 12: Differences in Beliefs Toward Paternalism by Type of Housing.................89

Table 13: Effects of Marital Status on Beliefs of Respondents..................................91

Table 14: Differences in Characteristics of Subjects.....................................................92

Table 15: Differences Between Cicirelli's Study and the Reykjavik Study.................94 


\section{Chapter I}

$\underline{\text { Introduction }}$

$\underline{\text { Elderly in Iceland }}$

Iceland is growing older, a transformation being experienced by many western societies. The older population in Iceland has increased far more rapidly than the rest of the general population for most of this century. The aging of Iceland is due to better health care and living standards, which in turn have resulted in higher life expectancies and lower birth rates. Iceland has one of the highest life expectancies in the world (Council of Europe, 1996).

In December 1, 1997, the total population of Iceland was 272,064 individuals. By then, the population of older persons 65 years old and older was 31,612 or $11.62 \%$ of the total population, thereof 19.374 or $61.23 \%$ lived in the greater Reykjavik area (Hagstofa Íslands, 1998, unpublished).

The projected growth of the older population in Iceland, 65 years and older, is expected to be around $15.3 \%$ of the total population by the year 2020 and around $19 \%$ in the year 2030. By then, total population of persons 67 years old and older will be around 54,000 (Hagstofa Íslands, 1997). The most significant increase is expected to be in the over 80 population. In 1995 , persons 80 years and older were $2.63 \%$ of the total population. The increase in projected growth of the over 80 population is expected to be $3.4 \%$ of the total population in the year 2020 and $4.3 \%$ in the year 2030 (Hagstofa Íslands, 1996). 
During the $20^{\text {th }}$ century, Icelanders have witnessed a major change from subsistence to industrialization, from diseases, famine and poverty to health and prosperity, from being politically dependent on another state to becoming a fully independent republic. This social shift has been experienced by the now aged population of Iceland. These changes as well as their cultural values of autonomy, independence and personal responsibility and knowledge of collective rights and obligations mark the now aging population (Wieland, D. G. 1994).

Icelanders cherish their independence and the individual is characterized as a true survivor, self-sufficient, self-managing and strong. Icelanders see themselves as links in a continuous tradition, where the concepts of autonomy and freedom are emphasized and have similar meaning. Through centuries the Icelanders have been influenced by an independent cultural spirit and the barren environment. The early peoples struggled for survival in a volcanic country by fishing and farming; they were often cut off from communication with others by landscape or weather-conditions (Ólafsson, 1985).

\section{Autonomy, an Occupational Therapy Heritage}

The profession of occupational therapy is centered on its core values which provide a basis for clarifying expectations between the client and the provider of services (AOTA, 1993). The ethical statement of the profession underlines the principles which are used to forward and maintain high standards of behavior in accordance with the values of the profession. Among those is a strong reference to collaboration with the recipient of occupational therapy services including the clients' involvement in setting 
goals and in deciding the course of intervention (A.J.O.T., 1994). The profession regards the individual as a functional member of society, an individual that is responsible for delineating what he or she needs to do, what he or she wants to do and how it is to be performed. Occupational therapy treats the whole person in his or her emotional, physical and social environment.

The profession has moved to address the questions of the role that occupation and activity have in relation to people's physical and social environment, along with client autonomy and a feeling of control. The focus is moving from the emphasis on the impairment of individuals and their need for treatment toward removal of exterior barriers, self direction and client control of support services (Craddock, 1996a). Many clients in the community have disabilities and frailties due to progressive conditions that call for changing needs. With a knowledge of the effects and prognosis of medical conditions and our understanding of the relationship of meaningful occupation, a balanced role mix to well-being can be offered to the clients for their use. A holistic approach sets physical impairment in the context of the person's emotional and psychological reality and his or her total environment. Our respect for each person's values and preferences should promote a belief in the right to autonomy and a selfdefined independence (Craddock, 1996b).

Attitudes and the Elderly

It is important for Icelandic occupational therapists to learn more about the beliefs and attitudes of the Icelandic people, including the elderly toward autonomy and 
paternalism in caregiving of the elderly. With the aging population and the increase in healthcare costs, issues of independence and autonomy will have an increased impact on health care services in the future. The aging of societies is going to mold the future of the profession. Occupational therapists have to become more proactive in health care of the elderly (Hasselkus \& Kiernat, 1989). Shorter hospital-stays and reduction in rehabilitation of the elderly within institutions calls for occupational therapy outpatient and community services. With a specialist knowledge of occupation and independent living (Hasselkus \& Kiernat, 1989), occupational therapists can improve the quality of life of the elderly by understanding their perception of autonomy and paternalism and by adding that knowledge to the base of the profession.

In general, people are inclined to have negative attitudes toward the elderly, attitudes which are mostly colored by impressions related to diseases and not the normal aging process (Árnason, 1993). True enough, some elderly people do decline in physicaland/or decisional capacity, either temporarily or permanently, and in turn become dependent. However, for the most part, normal aging is no hindrance to the routines and activities of every day life (Kielhofner, 1985). The Icelandic philosopher, Árnason (1993) writes, when commenting on attitudes toward elderly, that there seems to be a tendency to treat the elderly like children just because they are old. This age-discrimination is based on generalization about old people that is twisted and very untrue (Árnason, 1993). The frail elderly are the most likely group to be in danger of being paternalized in our modern society (Árnason, 1993; Cicirelli, 1992) which weighs human values according to productivity (Árnason, 1993). 
The effectiveness of modern technical medicine has shortened our clients' hospital stays to the extent that functional assessment and rehabilitation are dismissed in favor of medical treatment. The priority tends to be on the young, active members of society, with the weaker ones, such as the elderly, as less preferred service recipients. The older person is sometimes discharged to the home, unable to take care of him/herself and without time or chance to regain the abilities needed. Social home health services such as home help and home nursing is available in Iceland, but rehabilitation services are not yet available in the community, even though these services are mentioned in regulations on the services of health care centers. Because of a lack of community service, there is a big risk of confining the elderly client to a dependent sick role instead of an active, autonomous role. Occupational therapy services for the elderly are needed to help the elderly regain or sustain independence in the environment. Occupational therapy services need to be delineated in context to the community and home care.

Iceland is at least a decade behind its neighboring countries in extending community-based services; for Iceland, with its Nordic heritage, it seems right to look to the Nordic countries for models of occupational therapy services for community based elderly. These nations have years of experience in services which are based on occupational behavior, mostly personal and instrumental activities of daily living in the client's home, counseling, housing adaptations and helping devices. Through the years, Nordic occupational therapy services have expanded to assist in pursuing interests and supporting clients to plan social contacts and social life. Occupational therapists are helping their clients enhance their quality of life. In Denmark, rehabilitation has been 
taken over by the communities as an answer to the gap that is experienced by the elderly due to premature discharge from hospitals, with little or no rehabilitation of lost abilities. The goal is to give the community based frail people the possibility of continuity through a certain period of time in order to prevent repeated hospital admissions (Jensen, 1995).

\section{Application of the Model of Human Occupation}

The Model of Human Occupation was developed by Kielhofner (1995) to provide an explanation of occupational behavior. The model is based on general systems theory which describes individuals as open systems. Kielhofner defines the term occupation as being the action or doing through which people occupy their physical and social world. It includes three general areas of occupational behavior that is filled with meaning: play, work and daily living tasks. According to the model, the human system is composed of a hierarchy of three subsystems: volition, habituation and mind-brain-body performance. The volitional subsystem governs the overall system, it organizes the way individuals make and act out their choices based upon their values and goals. Habituation organizes occupational behavior into patterns or routines and the lowest level subsystem; the mindbrain body performance is responsible for enacting occupational behavior (Kielhofner, 1995).

Individuals function within the three subsystems as they interact with the environment which consists of culture, social groups, tasks and objects (Levy, 1993). The environment influences the way people choose, plan and act out occupation. It either provides opportunities by giving a certain freedom to choose and perform, or it presses 
for different types of behavior. Culture shapes the environment. It is inherited through generations with its norms and beliefs of social groups. A person's values, sense of competence, roles, habits and interests are connected to that person's connection to a specific culture or subculture, whether it is the home, neigborhood or other occupational behavioral settings (Kielhofner, 1995).

As people grow older they may experience chronic illness and deterioration of their mind-brain body processes associated with the normal aging process. They may experience difficulties in maintaining their daily occupations such as self-care, leisure and recreational activities as well as loss of roles and habits they have pursued through their lifespan (Kielhofner, 1995). The environment of elderly individuals may change due to temporary or chronic illness. Individuals who have lost the ability or opportunity to exercise their autonomy have suppressed their volition, their internal control of their environment, and diminished their function. Goals of function and independence and the autonomy of individuals to interact with their environment is highly regarded by the occupational therapy profession. Resolution of losses that impact these factors should form the basis of occupational therapy service goals (A.O.T.A, 1994) and be incorporated into the overall rehabilitation philosophy of health care teams working with the elderly client.

$\underline{\text { Statement of the Problem }}$

Currently, approximately one in ten Icelanders is older than 65 years of age. With the high life expectancy of today and the projected growth of the older population in 
Iceland, occupational therapists need to be more aware of elderly people's opinions about autonomy and paternalism in relation to caregiving of their age group.

Generally occupational therapists have always been interested in the beliefs of their patients and have been of the conviction that persons have the right to make their own decisions and act upon them. The focus of occupational therapy is to enhance individual autonomy and independence through functional and meaningful activities. In order for the elderly to feel competent and worthwhile, the environment has to provide them with opportunities to feel in control of their lives. Elderly people are, to a great extent, consumers of our health care system, not only within institutions, but also in the community. Chances for feelings of competence in this age group must, therefore, be provided in these matters.

Elderly persons exist in a delicate state of balance (Kiernat, 1991). To sustain this balance, a blend of support by caregivers and respect for autonomy is needed for the elderly to feel in control of their lives. Information regarding elderly persons' perceptions of autonomy and paternalism in caregiving of their age group may give an indication of how occupational therapists and other health care professionals may support autonomy when working with the elderly as health care providers.

The Purpose of the Study

The purpose of this study is to describe the beliefs of the elderly from the greater Reykjavik area concerning autonomy and paternalism in relation to caregiving of their age group. A comparison will also be made to see if there is a difference between the 
beliefs of older persons living in senior housing complexes to those living in their homes in the community.

\section{$\underline{\text { Research Questions }}$}

1. What are the attitudes and beliefs of Icelandic elderly individuals toward autonomy and paternalism in caregiving of the elderly?

2. Are there differences in the attitudes and beliefs toward autonomy and paternalism of older persons living in senior housing complexes compared to those living in their own homes in the community?

$\underline{\text { Significance of the Study }}$

The significance of the study is to describe the attitudes and beliefs of the elderly in relation to caregiving of their age group. It is important for Icelandic occupational therapists to learn about Icelandic elderly individuals' attitudes about autonomy and paternalism in caregiving of their peers because it is assumed that these attitudes will affect how people interact or care for the elderly.

\section{$\underline{\text { Definitions }}$}

The following operational definitions for this study were taken from Cicirelli $(1989,1992)$.

Personal autonomy: Having the capacity to make and execute deliberated decisions to satisfy needs and attain goals in a manner consistent with one's values. 
Respect for autonomy: To honor and accept the execution of personal autonomy by others.

Direct autonomy: Where the elderly person makes decisions and executes them by himself/herself.

Consultive autonomy: Where the elderly person makes the final decision after consulting with another to obtain information and opinions relevant to the decision making.

Joint autonomy: Where the elderly person and another individual share opinions and make a joint decision.

Delegated autonomy: Where the elderly person freely transfers the decision making to another individual and abides by the decisions that the other individual makes on the elder's behalf.

Surrogate autonomy: When the elderly person is no longer capable of decision making and another individual voluntarily assumes the decision making role. The individual tries to make the decisions in accordance with the elderly person's values and life plan.

Paternalism: Intervention in the making and execution of another person's decisions for the welfare of that person.

Direct or strong paternalism: When the expert or person in authority forces a decision or its execution upon another person, regardless of the latter's informed and voluntary choice.

Indirect paternalism: When the expert or person in authority uses deception or manipulations to impose decisions and/or his/her execution upon another person. 
Benevolent paternalism: When the expert or person in authority interacts and participates in a decision with the dependent person to explain what is best (as the dependent person may be living in ignorance or in false beliefs) and the necessity for imposing the decision. The expert or person in authority intervenes only to prevent harm.

Weak paternalism: When the expert or person in authority intervenes only when there is mental deterioration.

Moderate paternalism: When the person in authority intervenes only to prevent harm.

Default paternalism: When the dependent person is capable of making informed and free choices but is totally indifferent to doing so. Since decisions must be made, the expert or person in authority must make them.

Belief: A subjective judgment that objects (or ideas) exist, tends to be durable and influence behavior (Cicirelli, 1989) .

Caregiving: The act of providing assistance to an individual in need (Cicirelli, 1990) .

Caregiver: A person providing some degree of care in response to an older persons needs (Horowitz \& Dobrof, 1982; Cicirelli 1990) .

Care receiver: Individual who receives care.

Caregiving dyad: The relationship between the caregiver and the carereceiver.

Older person: A person 65 years or older.

Confused mind: Describes a range of behaviors that causes problems for an individual. Descriptors include being forgetful, confused, no longer thinking clearly and senile.

Sound mind: Describes an individual who has no mental or cognitive problems. 


\section{Assumptions:}

1. Autonomy and paternalism do exist as basic human characteristics.

2. Autonomous people do exist.

3. The belief in respect for autonomy is the recognition of the idea that people have the right to be autonomous.

4. Behavior is affected by people's attitudes.

5. Self-report measures are suitable to use when defining the direction and the intensity of attitudes.

6. Respondents to the interview questionnaire will answer honestly and truthfully to the best of their ability. 


\section{Chapter II}

\section{Review of the Literature}

\section{$\underline{\text { Aging in Iceland }}$}

Icelanders are growing older; the main reason for this "graying" of the nation is the increase in average life expectancy and overall drop in birth rates. For the years 1994 and 1995 combined, life expectancy was 76.5 years for men and 80.6 years for women. The average infant mortality rate for the years 1991-95 was 4.7\% (Council of Europe, 1996).

Since 1985 , the Icelandic population has grown by $10.4 \%$ or $0.99 \%$ per year. The number of children aged $0-14$ years has grown by $3 \%$, but as a proportion of the total population, this is a decrease from $26.1 \%$ to $24.4 \%$. The proportion of the age groups 15 44 years has grown by $9 \%$ which is a decrease from $46.6 \%$ to $46.0 \%$ of the total population. The first group increasing in proportion is the 45-64 years age group with a little over $1 \%$ increase per year $(17.1$ to $18.3 \%)$. The age group 65 years and over also has increased from 10.2 to $11.2 \%$ of the total population and the number of the very old, 85 years and over, has increased by a total of $23 \%$ during the last decade (Council of Europe, 1996).

Iceland is still younger than its neighboring countries, as can be seen by statistical figures that are lower than can be found concerning the same age groups living in the other Nordic countries. As an example, latest available data from Norway of total percentage of population by age groups are: $0-14$ years, $19.5 \%$; $15-44$ years, $43.1 \%$; 45- 
64 years, $21.5 \%$ and for the age groups 65 years and older, $15.9 \%$ of the total Norwegian population (Council of Europe, 1996).

In December 1, 1997, the total population of Iceland was 272,064 individuals. By then, the population of older persons 65 years old and older was 31,612 or $11.62 \%$ of the total population of which 19,374 or $61.23 \%$ lived in the greater Reykjavik area (Hagstofa Íslands, 1998, unpublished) .

The projected growth of the older population in Iceland, 65 years and older, is expected to be around $15.3 \%$ of the total population by the year 2020 and around $19 \%$ in the year 2030. By then, the total population of persons 67 years old and older will be around 54,000 (Hagstofa Íslands, 1997). The most significant increase is expected to be in the over 80 population. In 1995 , persons 80 years and older were $2.63 \%$ of the total population. The increase in projected growth of the over 80 population is expected to be $3.4 \%$ of the total population in the year 2020 and $4.3 \%$ in the year 2030 (Hagstofa Íslands, 1996).

Icelanders are an island nation living on the northernmost edge of the Atlantic Ocean, just under the Arctic Circle. Iceland was settled by Nordic people, who established a commonwealth in 930 A.D. The commonwealth prospered and created a flourishing cultural life based on laws and values which the settlers brought with them to the new country. This political arrangement produced a balance between freedom and equality which has been sustained by the nation in spite of foreign rule through the last six centuries. These cultural values are just as evident in the modern society and modern 
literature as they are in the medieval Icelandic sagas which helped preserve the characteristics of Icelandic culture (Ólafsson, 1985).

During the $20^{\text {th }}$ century the aged population of Iceland have experienced a social transition. Icelanders have witnessed a major shift from subsistence to industrialization, from diseases, famine and poverty to health and prosperity, from being politically dependent on another state to becoming a fully independent republic. These changes as well as their cultural values of autonomy, independence and personal responsibility, and the knowledge of collective rights and obligations mark the now aging population (Wieland, D. G. 1994).

Today, Icelanders live in a society marked with individualism and a society without class distinction where everyone expects to be regarded as an equal. The individuals expect to be regarded for being what they are and respected for their value as human beings. This individualism is rooted in equal proportions of freedom and equality which have been inherited through generations. With the dominant ideologies of nationalism and equality, the elderly are respected in many ways as witnesses to a revered past, and as exemplars of Icelandic cultural identity (Ólafsson, 1985). Their somewhat idealized status can be seen in commemorative anniversary biographies of prominent older persons or voluminous obituaries in newspapers. Another factor is the active participation of the elderly in the workforce. The work ethic has always been very strong in Iceland and the older generation, who value work for work's sake, has continued in productive roles while physically and mentally able, preferring work over retirement (Wieland and Pálsdóttir, 1986). In April 1996, 76.9\% of elderly 60 - 69 years 
old were working and $12.4 \%$ of persons $70-74$ years old were still on the work force (Hagstofa Íslands, 1997).

Since the middle of the century, a rapid urban shift has brought about selective changes in the geographic distribution of older Icelandic adults. Elders have moved increasingly to the urban areas, especially to the greater Reykjavik area, where there is a concentration of formal and informal services. Another factor contributing to this urban migration of the elderly is the greater availability of adult children in the area. As a result, the elderly population is proportionally higher in urban areas than in the total population. Of special concern is the fastest growing subgroup, the oldest-old (Wieland and Pálsdóttir, 1986).

The social conditions of the elderly in Iceland have improved steadily through the century. The modern Icelandic social security system is a result of legislation through many decades. It has evolved independently, although in many ways it resembles the the other Nordic systems which have served as models. The national social security system is financed mainly from central government revenues. Today's social security system consists of a basic national social security insurance (based on years of domicile), financed from general revenues, and a variety of special supplementary pension funds which are financed by employer/employee contributions with levels of benefits determined by contribution years. Old-age pensions are automatically paid out to persons 67 years and older who have been domiciled in the country at least three years between the ages of 16 to 67 . However, full old-age pension is only paid to those who have been living in Iceland at least 40 years between those ages (Wieland and Pálsdóttir, 1986). 


\section{Attitudes}

The modern society, which tends to rank human value by productivity, is not always a good place in which to live for the older person, especially those who are dependent in some way. Ageism is rooted in the culture of modern society and its stereotypes about old people are twisted and most untrue. These stereotypes are mostly negative attitudes that lead to unrespectful and unequal treatment of older persons (Árnason, 1993).

Over the past decades, many studies have been carried out which report the respondents' views of the aged and the problems that they face are quite negative. Several researchers have attempted to identify the variables that influence attitudes toward the elderly; such as the elderly being judged to be weak and dependent and of lower competence, intelligence, and attractiveness than the young.

Attitudes of the aged. Seccombe and Ishii-Kuntz (1991) studied how perceptions of aging and the problems the aged face differ among four elderly age groups, since they suspected that persons in different age cohorts would have different views on aging issues. Their assumptions that middle aged persons would be most pessimistic was supported by their results, whereas contrary to their expectations, the oldest-old age group proved to be surprisingly optimistic. These findings suggest that our youth-oriented culture influence the attitudes and maybe exaggerate the difficulties faced by elderly people (Seccombe and Ishii-Kuntz, 1991).

Hummert and others (1995) measured the attitudes of three different adult age groups, where 125 adult participants rated typicality and approximate age of individuals 
representing 11 stereotypes of the elderly. The participants stated their attitudes by choosing descriptions of bipolar stereotype sets. Results showed that adults of all ages shared similar beliefs and attitudes about stereotypes of older persons, although the elderly respondents held more positive attitudes toward all stereotypes than did the young and middle aged respondents. The older ranges were generally chosen for the more negative stereotypes and the younger age ranges for the positive ones. Thus, age played a significant role in all judgements of the stereotypes, although the nature of the stereotypes themselves was a stronger factor. The respondents of all ages (young, middle-aged, and elderly) chose the older ranges for the more negative stereotypes and younger ranges for the positive stereotypes (Hummert and others, 1995).

Attitudes toward the aged. In a descriptive study by Giardina-Roche and Black (1990), attitudes of diploma nursing students toward adult clients of various ages and in different health situations were examined. The study was conducted by using a personperception-paradigm approach. Data analysis revealed that nursing students were not interested in working with the elderly, and that students with more past experiences with elderly persons tended to show more positive attitudes toward elders.

Similar conclusions are seen in an article published by Gillis (1991) on strategies to promote positive behavior toward elderly patients. There she states that one should be aware of factors that result in negative attitudes and behavior toward the elderly. To be able to effectively choose intervention strategies, Gillis includes a list of identified variables that influence positive attitudes of nurses toward elderly persons. The affecting 
variables are: age, setting, length of service, formal educational level, prior work experience, presence of aging role models, exposure to positive role models, ethnic background, degree of functional impairment of the elder, geriatric speciality units and degree of exposure to elders in the work setting. These variables were established through nursing research. Apart from these variables, Gillis mentioned that inadequate gerontological content in the professional curriculum might have an effect on nurses' attitudes.

In their study, Brown and others (1992) measured if attitudes of physical therapy students could be influenced positively using traditional and geriatric mock clinics. The orientation spurred intense discussions on the students' positive and negative attitudes toward the elderly. The elderly volunteers involved in the mock clinics were interesting, well-educated and active participants in a diversity of community activities. Original expectations of the researchers proved true and they concluded that students'attitudes toward the elderly could be improved using direct contact with positive elderly patients. Positive attitude scores increased significantly for both groups (Brown and others, 1992).

Socialization with the elderly is recognized as one component in the educational preparation of the health care professional. Positive and negative attitudes are sometimes displayed and accepted by people without thoughtful considerations. In 1993, Heilken and others published an article on the confirming results of their research question: Is it possible during the initial portion of a health focused educational program to introduce an enjoyable experience with older adults, and by doing so, influence the students' attitudes 
toward the elderly in a positive way? Their study was based on the assumption that negative attitudes toward the elderly existed as a result of a socially constructed perception of ageism, and that ageism was found to be widespread in the medical care system. The researchers hypothesized that given an opportunity to interact with the well elderly in their academic preparation, students would form a positive attitude toward older adults. Students from medicine, nursing and dentistry were participants in the study. The researchers concluded that attitudes of students could be influenced by positive experiences with well elderly persons during the early period of their professional educational progress (Brown and others, 1992).

\section{Home Health Care in Iceland}

It is generally accepted that one of the most important factors in enabling the elderly person to lead an independent life is effective home based community support services. The development and co-ordination of support services are the joint responsibility of the boards of health centers and the social services council in each district (Pálsdóttir, 1986).

According to the Annual Report of the Reykjavík Social Service, a total of 2,443 clients in 2,037 homes received home care services in the year 1995 (Félagsmálastofnun, 1996). One hundred forty nine homes received formal support on a daily basis (weekends excluded), of which 95 homes were also supported by their families. There was no identification on the type of support that was given, e.g. cleaning, cooking, shopping, socialization, or companionship. Through the years there has been a steady increase in the number of recipients of home care services. The biggest group has been the elderly, 
with half of the clients in the age group $75-85$ years. This calls for changes in the services to the elderly (Sigurgeirsdóttir, 1991). The emphasis of support services is expected to change. It can be expected that the importance will move away from instrumental activities of daily living, toward social contacts and assistance in activities of daily living. The emphasis then has to be on respect for the client's autonomy, with the client treated as a social equal (Sigurgeirsdóttir, 1991).

In the year 1982, the Althing (the Icelandic Parliament) passed legislation on services for the elderly (Lög um málefni aldraðra) which was revised in 1989 and again in 1997 (Heilbrigðis og tryggingamálaráðuneytið,1997). The main objectives of the statute was the promotion of comprehensive care, the integration of services to enable the elderly to live independently for as long as possible, and the provision of necessary institutional care when appropriate. The legislation states that autonomy shall be respected. It entitles the aged to services that are needed, such as support to live in their homes as long as wanted or access to a nursing home when such a need rises. At the same time, it postulates that needs are to be met at a level that is relevant and economical (Heilbrigðis og tryggingamálaráðuneytið, 1997; Pálsdóttir, 1986). This was an effort to co-ordinate medical and social services for the elderly with the emphasis on linking the needed services to already existing services, such as the medical services of health centers around the country, and community services, such as home help and meals-onwheels, offered by the municipalities. The real targets of the legislation were the urban districts in which geriatric team care and case management were expected to be most needed. The fact that health care service personnel are employees of the state, whereas 
the staff of social services are employed by the municipalities, has delayed the implementation of the statute.

The legislation also encouraged the rapid construction of senior service housing complexes through its matching financing of municipal and district construction funds for the elderly. Although the intentions of the Althing had been that the municipalities or other bodies would rent these apartments and charge service co-payments to community elderly in need of community based health and social services, the trend, especially concerning the senior housing and sheltered complexes, was toward self-ownership where most of the apartments were built or bought by elder persons. Elderly people that are considerably well off, and needing some or minimal assistance, still seem to be attracted to this option.

In her article on "Gamalt fólk í Evrópu" (The elderly in Europe), Sigurgeirsdóttir (1994) reported lectures from a European conference on aging. She recounts that in the Nordic Countries it is expected that emphasis will be on autonomy of the elderly, continuity in their lives, and safeguarding their personal as well as economical strength. In Iceland there is a similar trend, consisting of highly developed services for the elderly, emphasizing independence and autonomy (Sigurgeirsdóttir, 1994).

For Iceland, with its Nordic heritage, it seems right to look to the Nordic nations for models of occupational therapy services for community based elderly. These nations have years of experience with their services based on occupation, primarily personal activities of daily living and instrumental activities of daily living in the clients home. In the Nordic countries, occupational therapists are recognized for counseling the disabled, 
housing adaptations and recommendations of helping devices. Through the years, services have expanded to assistance in pursuing interests and supporting clients' planning social contacts and social life. Today, many communities in Denmark have taken over the rehabilitation of the elderly and disabled as an answer to the gap that is experienced by their frail clients due to premature discharge from hospitals with little or no rehabilitation of lost abilities. Outpatient services are now offered by community rehabilitation clinics to dependent clients, either individually or in homogenous groups. Jensen (1995) reports the positive results of a Danish experimental project carried out in 1992-1994. A rehabilitation center was established as an additional support to the formerly decentralized work of the community based occupational and physical therapists. The goal of the project was to give the community based clients a possibility of continuous training through a certain time, in order to prevent repeated hospital admissions. This is now a permanent service to community living elderly in some counties in Denmark on the sole condition that the client is motivated for active participation in the training (Jensen, 1995).

\section{$\underline{\text { Informal Caregiving }}$}

The most consistent finding in caregiving research is that the majority of caregivers are women, either spouses, adult daughters or daughters-in-law. This prevalence of women and the tendency to describe the caregiver role as being mainly assistance in personal care activities highlight the image of caregiving as predominantly a female task. Himes (1994) examined the risk and practice of parental care over the life of 
adult women, using methodological techniques of demography. Analysis revealed that over one half of adult women with a surviving parent can expect to provide care to that parent at some point in the future, and that the lengthening of life expectancies are apt to increase the prevalence of caregiving and the ages at which it will occur (Himes, 1994).

It has been hypothesized that a number of variables influence how caring for a frail elderly person has on family functioning. Among those are: the quality of the relationship between caregiver and receiver, family values and interaction processes, shared versus independent living arrangements, caregiving consequences for work and availability of formal resources and other caregivers.

Quality of role experiences refers to the amount of costs and benefits experienced within that specific role. Little attention has been given to issues of role quality in family caregiving and how the different roles influence well-being beyond the influence of the caregiver role. Stephens, Franks and Townsend (1994) examined role-specific stress and rewards experienced by 95 women who were simultaneously in the roles of caregiver, mother and wife. The findings supported researchers predictions that these caregiving women (daughters and daughters-in-law) would not only experience stress in their three roles but also many rewards in these same roles. The unique contribution of stress and rewards to well-being supports the importance of considering different inputs of role experiences when women's physical and mental health are examined. Findings indicated that the accumulation of stress across roles can be detrimental to women's well-being, and that the accumulation of positive experiences across roles can be beneficial. A spillover effect was evident in the study, pointing most strongly to the mother and wife roles. Stress and rewards in the women's roles as mothers were more consistent and more 
related to well-being than were stress and rewards in the caregiving roles. Suggestion is made that multiple roles should be examined in terms of quality and not simply in terms of role occupancy (Stephens, Franks and Townsend, 1994). Similar findings are reported by Stephens and Franks (1995) from their examination of how the role of caregiver and wife affect one another and how spillover effects are related to caregiver well-being. The spillover was measured from the perspectives of 125 adult daughter caregivers and their husbands. The husbands reported less negative spillover and more positive spillover from the caregiver role to the wife role than did their wives. The adult caregiving daughters reported more negative spillover from their parent-care role to their wife role than in the opposite direction. Findings support prior research findings that women's psychosocial well-being is influenced by the number of roles they occupy and furthermore, results suggest that the influence of the parent-care role can also be beneficial (Stephens and Frank, 1995).

In 1992, Miller and Cafasso reported on their meta-analysis study of the results of 14 descriptive studies of gender differences in caregiving. The purpose of their study was to provide a base for interpreting the theoretical and practical implications of gender differences in caregiving stressors and burden based on gender-role and social role perspectives. Results indicated that there were no significant gender differences in functional impairment of the frail care receiver or the level and task involvement in care or money management. Women were more likely to take responsibility for personal care and housekeeping tasks, although the effect of those tasks on gender differences was small. Correlations were positive showing that female caregivers were more likely to report greater burden than did male caregivers. Results also supported the elements of 
both gender-role socialization and social role perspectives. The researchers concluded that the social role perspective is more useful in terms of explaining caregiving task behaviors, e.g. why men are more likely to take on caregiving tasks that are finite and subject to scheduling, and that the gender-role socialization perspective appeared to be more useful in understanding caregiver appraisal or emotional responses to caregiving. Miller and Cafasso (1992) emphazised that what is needed is to pay more attention to the role that gender-roles play in assigning meaning to the caregiving experience.

Caring for an older person can include both pain and satisfaction, self-doubt and self-discovery. What is it that keeps caregivers in the role that gives them the courage to build a life during and after the caregiving period is over? In a qualitative study Langner (1995) focused on the meaning of the experience as expressed by family caregivers of elderly people and the role this meaning holds in supporting the family member in the caregiving role. Her article explains both the painful and the satisfying aspects of caregiving as related to heightened awareness of the caregiver role and of self. Two common themes emerged: the respondents were confronting (a) a new reality as caregivers, acknowledging the change in the relationship with the older person, finding themselves off balance and asking, "Who am I now?" and "Where do I fit in this?" They had to redefine the future in terms of here and now and a change of roles for both the elder and the caregiver and (b) a rediscovery and redefinition of themselves: the caregivers expressed their loss and pain as well as the growth producing effects of these elements that spurred their coping strategies as they rediscovered themselves as capable, competent, deserving and resourceful individuals. The subjects discovered that they were solving problems and doing things they had not thought themselves capable of; they were 
surprised by their own strength and resilience. Langner (1995) reported that the satisfaction of redefinition of self as competent, deserving and resourceful was striking and a repeated theme in the caregiver narratives. She pointed out that the caregivers were able to use their contemplations of the meaning of the experience to enhance personal growth and to sustain them in the caregiver role (Langner, 1995).

Smith, Smith and Toseland (1991) reported their in-depth analysis of the pressing problems that family caregivers elected to address in individual counseling programs. Caregiver problems were analyzed and categorized and each of seven categories was discussed in terms of relevance to clinical practice with caregivers. Findings indicated a number of issues to be addressed in psychoeducational programs for family caregivers, such as working on improving coping skills and involving other family members in counseling, helping caregivers to better understand and respond to the care receiver's psychosocial needs, encourage caregivers to talk about their feelings of distress and to use formal and informal services. The authors of the study found it noteworthy that many of the problems identified were caregivers' expressions of underlying concern about sharing the caregiving responsibilities while keeping absolute control over the caregiving situation. Thus, their solution to time management problems was centered around being more organized rather than handing over any caregiving responsibilities (Smith, Smith and Toseland, 1991).

Modernization of societies has brought on changes in social exchanges and family ties, changes in family structure, the participation of women in the working force along with increased geographic mobility. Geographic distance has received much attention for its role in structuring opportunities for social exchange between extended families. 
Silverstein and Litwak (1993) examined a typhology of intergenerational social support structure with data of older adults and their primary children helpers. Results showed that older unmarried and more disabled parents were significantly more likely to be a part of a traditional rather than a modified extended type of relationship with their children. Thus, physical frailty and being single can be viewed as a factor that elicits household support from adult children. Generalized values concerning intergenerational family obligations clearly molded supportive behavior at the individual level. A larger family size and having unmarried children improved the likelihood of being in a traditional arrangement. Distance and coresidence variables were statistically significant. Elderly parents who lived closer to their primary caregiving children were more likely to be in traditional relationships than in a modified-extended one. Neither functional health nor parental marital status influenced whether social-emotional support was provided. Socialemotional activities were easier to maintain over shorter distances, although distance as a barrier to social-emotional support is at least partially overcome through the use of modern travel and communication technology. The researchers conclude that in the future formal community-based services will become crucial for keeping elderly parents living independently at home by complementing with informal care. Predicted lower birth rates will call for innovative task sharing arrangements between formal and informal systems to relieve caregiver burden and to insure that well-intentioned children continue to care for their frail and aged parents (Silverstein and Litwak, 1993).

In some countries, the increasing government role in providing care for the elderly may have resulted in the impression that the responsibility for assistance has 
shifted from one's own family to government. However, public support will never provide the same kind of care and emotional support as can be provided by the family.

Wolfson and others (1993) examined how adult children in Canada perceived responsibility for their parents' physical, financial and emotional needs, asking the adult children for their perceptions about hypothetical cases in vignettes in order to obtain measurements of their attitudes. Results indicated clearly that Canadian adult children felt a strong moral obligation to provide care for their elderly parents. The respondents believed that families should provide support to frail elderly persons. The respondents' perceptions of their abiliy to provide emotional support was predominant, followed by the ability to provide physical and lastly financial assistance. Physical assistance might be perceived as requiring more effort and time and not possible due to busy work schedules and family life. The researchers pondered that families might feel that physical and financial support is the responsibility of the government, or that family closeness and devotion are valued attributes that can exist in spite of inability to provide physical assistance. These findings point to a gap between respondents' feelings of what should be done and what they perceive they could actually do, especially for financial support. In their conclusion, Wolfson and associates (1993) suggested some interventions such as, to focus home care programs on the opportunity to work with families who wish to be involved in caregiving of elderly parents and to improve social acceptance of certain dysfunctions such as urinary incontintinence (Wolfson and others, 1993).

The competing demands of work and elder care were the subject of a study carried out by Stone and Short (1990). It is known that caregivers who reduce their working hours, take time off without pay, or quit their jobs because of elder care 
responsibilities will sustain financial losses in wages and employment-related benefits, in addition to emotional costs. Employers are also faced with decreased productivity due to absenteeism and poor morale, added to the costs of replacing valued employees. One of the goals of the study was to model the correlate of accomodation among working caregivers. Findings demonstrated that primary caregivers and those caring for elders with greater care needs are more likely to take unpaid leave, reduce their working hours or rearrange their work to assume their caregiving responsibilities. Findings also suggested that being a white woman in fair to poor health also increased the likelihood of work accommodation. However, after controlling for the likelihood of work accommodation, need for care, and availability of others to take on caring responsibilities, it is more likely that younger, white and more highly educated women caregivers will remain employed. Those who chose not to combine work and caregiving responsibilities seem to have less to gain, financially and emotionally, from working (Stone and Short, 1990).

Occupational Therapy and Autonomy

The profession of occupational therapy is centered on its core values which provide a basis for clarifying expectations between the client and the provider of services (AOTA, 1993). The ethical statement of the profession underlines the principles which are used to forward and maintain high standards of behavior in accordance with the values of the profession. Among those is a strong reference to the collaboration with the recipient of occupational therapy services, the clients' involvement in setting goals, and in deciding the course of intervention (AJOT, 1994). The profession regards the 
individual as a functional member of society, an individual that is responsible for delineating what he needs to do, what he wants to do and how it is to be performed. Occupational therapy treats the whole person in his or her emotional, physical and social environment.

The profession has moved to address the questions of the role that occupation and activity have in relation to peoples' physical and social environment, along with client autonomy and a feeling of control (Craddock, 1996a). Many clients in the community have disabilities and frailties due to progressive conditions that call for changing needs. With a knowledge of the effects and prognosis of medical conditions and our understanding of the relationship of meaningful occupation, a balanced role mix to wellbeing can be offered to the clients for their use. A holistic approach sets physical impairment in the context of the person's emotional and psychological reality and his or her total environment. Our respect for each person's values and preferences should promote a belief in the right to autonomy and a self-defined independence (Craddock, 1996b) .

When discussing occupational therapy's perspectives of the disability movement, Craddock (1996a) refers to De Jong's comparison of the "Rehabilitation Paradigm" and the "Independent Living Paradigm" as the equivalents to the medical and social models of disability, stating: "In the Independent Living Paradigm (or social model), the focus is moved from the emphasis on the impairment of individuals and their need for treatment by professionals. Instead, the removal of exterior barriers and the self-direction of disabled people and control by them of support services are advocated" (p. 20). 
Independence of a person is apt to change through a lifespan, in the context of a person's roles and habits, or when a person is not able to perform activities due to disability or frailty of the older population. When individuals become incapable of making or executing their own decisions, they become dependent on others to carry out their decisions and may experience a loss of a former actual or perceived control (Kiernat, 1987).

It is important for Icelandic occupational therapists to learn more about the beliefs and attitudes of the Icelandic people, including the elderly, toward autonomy and paternalism in caregiving of the elderly. With the aging population and the increase in healthcare costs, issues of independence and autonomy will have an increased impact on health care services in the future. The aging of societies is going to mold the future of the profession. Occupational therapists have to become more proactive in health care of the elderly (Hasselkus \& Kiernat, 1989). Shorter hospital stays and reduction in rehabilitation of the elderly within institutions call for occupational therapy outpatient and community services. With specialist knowledge of occupation and independent living (Hasselkus \& Kiernat, 1989), occupational therapists can improve the quality of life of the elderly by understanding their perception of autonomy and paternalism and by adding that knowledge to the base of the profession.

\section{Autonomy}

Cicirelli (1992) defines personal autonomy from his psychological perspective, saying: "For an individual, personal autonomy means having the capacity to make and 
execute deliberated decisions to satisfy needs and attain goals in a manner consistent with ones values" ( $p$ 14). He notes that the execution of autonomy may be interfered with by criterions such as young age, mental illness, internal constraints (such as unwillingness to make decisions) or external constraints (e.g. rules of the society). A certain competence is needed to be autonomous. The person must have certain cognitive abilities such as logical reasoning, judgment, ability to reflect upon and consider alternatives, problem solving abilities and capacity to exercise in accordance with decisions.

A belief in autonomy is one's acceptance that other people have the right to make choices and act upon those choices without intrusion by another individual. Cicirelli (1989) summarized five types of autonomy.

1.) Direct autonomy is when the elderly person makes decisions and executes them by himself.

2.) Consultive autonomy is when the elderly person makes the final decision after consulting with another to obtain information and opinions relevant to the decision making.

3.) Joint autonomy is when the elderly person and another individual share opinions and make a joint decision.

4.) Delegated autonomy is when the elderly person freely transfers the decision making to another individual and abides by the decisions that the other individual makes on the elderly person's behalf.

5.) Surrogate autonomy is when the elderly person is no longer capable of decision making and another individual voluntarily assumes the decision making role. The 
individual tries to make the decisions in accordance with the elderly person's values and life plan.

In 1984, an article was published by Thomasma where he described five freedoms connected to autonomy: 1) Freedom from obstacles to carry out one's desire, 2) Freedom to know one's opinions, 3) Freedom to choose or make a decision, 4) Freedom to act on that decision, and 5) Freedom to create new opinions.

In his essay on "Hugtakið sjálfræði" (The Concept of Autonomy), the Icelandic philosopher Frímannsson (1993) admits that autonomy is a complex concept, but very transparent in the Icelandic version "sjálfræði" where, like what is so common in the Icelandic language, the word explains itself. It means self-rule or self-determination. In older writings the concept of independence can also be seen as equivalent to autonomy. Frímannsson defines autonomy:

Autonomy is the ability to decide, unrestrained, between two choices of action primarily concerning oneself....Autonomy gains its importance through our beliefs that every person should decide for himself all or almost all the most important decisions in his life; everyone should be the maker of his own fortune ( p. 154).

Frímannsson (1993) emphasizes the contemporary opinion, that a person should decide autonomously on actions concerning oneself, as long as the decisions do no harm to others. Each person should mold his or her life and be responsible for its course, content and aim. In Frímannson's mind, this refers to the mature adult, capable of making rational, unrestrained decisions between different options. However, there may be some 
exceptions, e.g. children, some elderly people, and developmentally and mentally disabled persons who may lack the competence to make the best choices concerning their well being. It may then be an option to accept the intervention and decision making by another more competent person. Within the concept, Frimannsson points out two important factors that have to be taken into account: (a) The competence to sustain strong emotions, i.e. the ability to see, understand and act according to favorable courses and (b) the competence to be free from the overpowering will of others, e.g. threats or social pressure.

In contrast to internal autonomy, Frímannsson (1993) describes external autonomy as a "threshold" set by society, limited or confined to ethical and rational views about the nature of man, or most likely both. "Thresholds" or constraints differ from one society to another, since societies are different in complexity and with different social needs. In general, autonomy and ethical rules may differ vastly between highly developed societies and the more primitive ones. The autonomous man is a link in a continuos tradition, he does not pick his ethical rules like an item off a shelf in a grocery store. He inherits them as a part of a traditional way of thinking, activates them when reflecting on the world around him and on himself and the society (Frímannsson, 1993).

In his book "Siðfræði lifs og dauða" (Ethics of Life and Death), Árnason (1993), another contemporary philosopher, shares the view of his countryman Frimannsson on individual autonomy and its execution. The respect for a person as a human being is to prevail in all communication with people. A respect built on ethical equality of persons who are capable of judging their own actions and molding their lives in context to 
culture, tradition and society. Autonomy is respected, not by showing total indifference, but by keeping distance, by giving a person "space" to shape the contents and purpose of his or her life. Árnason postulates ethical benefits of persons built on respect for the autonomy of persons and care for the welfare of persons.

In communication between health professionals and their clients he states that the main difficulty seems to be connected to the obligations of professionals to guard and enhance the health and welfare of their clients - whether autonomous or not. The danger is that they might consider that their professional experience and expertise make them more competent than the client to guard his or her welfare. In contrast, respect for the client's autonomy might demand that the personnel back off and respect the client's decisions even though it contradicts professional judgment of what would be best. Tension might arise between the decision to respect the client's autonomy and caring for his or her welfare. He expresses criticism of the paternalism of the health professions, where the concept of benevolent welfare often has been given more value than the client's autonomy (Árnason, 1993).

In his discussion of communication between professionals and clients when making difficult decisions, Árnason (1993) advocates communication built on mutual trust and joint responsibility, a joint autonomy and a dialogue. This does not mean that each individual explains his values and then avoids acting in a way that might oppose the values of the other. On the contrary, he explains that a professional shows his patient respect by criticizing his or her values and opinions when, in his opinion, they oppose the patient's benefits. By doing so, he is referring to the patient's freedom of choice, his 
judgment and responsibility, not agreeing without criticism of the patient's "sacred" values.

On issues regarding autonomy and the aged, Árnason (1993) states that autonomy is the key of self-image and dignity for every individual, young and old alike. In service of and communication with the aged one has to be aware of the fact that, apart from declining capacity of an aged person, there are several factors that threaten the older people's autonomy. Issues like attitudes and ageism and the intervention of relatives and paternalistic actions of professionals may affect autonomy, as well as the rules and habits of institutions, group pressure and insecurity of the individual (Árnason, 1993).

In his essay "Forsendur sjálfstæðis" (Prerequisites of Independence), the Icelandic philosopher Skúlason (1995) contemplates the concept of independence for the individual and the nation. Generally speaking, he writes, "the independence of a nation is most frequently equated with political independence, i.e. whether a nation has the right and capacity to decide on its own affairs, that is, what is called an independent or sovereign state"'(p 111). To be independent is to be autonomous, to rule one's own actions, and the expectation that people respect one's right to exercise one's independence. Like Frímannsson (1995) when explaining autonomy, Skúlason (1994) states that the concept of independence has two components: external constraints like the interference by others, and internal constraints which concern the capacity to rule oneself (Skúlason, 1995).

When a deliberate decision has been made by a person, it has to be executed to fulfill needs or to reach goals according to the values of the individual. A person may lack the capacity to exercise his autonomous decisions due to internal constraints (e.g. 
unwillingness to decide), or external constraints (e.g. rules of the environment). This means that there may be individual differences concerning decisional competence as well as difference in opportunities for making choices that lead to exercise of autonomous actions. A person may have decisional capacity without having the capacity to exercise his decisions. The patient then has partial autonomy, as described by Cicirelli (1992), when referring to Collopy $(1986,1988)$ who distinguishes between decisional and executional autonomy. Health professionals frequently meet patients whose executional autonomy is lost, e.g. amputated patients, stroke patients and persons paralyzed due to accidents. The obligation of the professional then is to inform, support and help the person to carry out their decisional autonomy.

As a contrast to direct or personal autonomy, delegated autonomy exists, according to Collopy (Cicirelli 1992; Collopy 1986, 1988). It is unanimously accepted where children are concerned, but a more delicate issue where older adults are concerned. Árnason (1993), when referring to the elderly and attitudes of people towards the aged writes, that there seems to be a tendency to treat the elderly like children, only because they are old. Such an attitude can be called age-discrimination, which has similarities to race-discrimination or discrimination based on generalizations about old people that is twisted and most untrue. According to Árnason the elderly are the most likely group of people, in danger of being paternalized in a society which weighs human value according to productivity. Some elderly people do decline in their decisional capacity and become unfit to carry their decisions out with success (Cicirelli, 1992). Some geriatric illnesses may show syndromes, that present themselves with temporarily distorted understanding, reasoning, and decisional capacity, even though the individual may in between be capable 
of clear judgment. If this is the case a careful dialogue and other communication is needed to bring about a joint conclusion. If there is uncertainty of successful or nonharmful effects, all or part of the decision making may best be handed over to others. By recognizing partial autonomy, premature paternalism can be avoided (Árnason, 1993; Cicirelli, 1992).

$\underline{\text { Paternalism }}$

Definition of paternalism. Paternalism is the moral right to act for another individual, or to force the individual to act, when that action is for the good of the individual concerned (Cicirelli, 1989). Paternalism is not a sign of a selfish improper attempt to rule over weaker persons. People act paternalistically believing that they know what is best for the other person. In his book, Árnason (1993) explained that there are two stages in life where persons are apt to be exposed to paternalism: when they are children, and in old age, especially when they have declined in mental or physical capacity and have to receive assistance from others (Árnason, 1993).

Six types of paternalism. At the beginning of his study, Cicirelli $(1989,1992)$ constructed a paternalism questionnaire. The Paternalism Scale consists of 30 items based on six types of paternalism that have been defined by ethicists such as Collopy (1986), Gillon (1985), and Young (1986). The Scale consists of the following subtypes of paternalism:

1) Direct or strong paternalism is when a person in authority intervenes in another person's decision making without that person's welfare. 
2) Indirect paternalism is when a person in authority uses deception or subtle manipulation to intervene.

3) Benevolent paternalism is when a person in authority participates in the decision, explaining its necessity to the individual.

4) Moderate paternalism is when a person in authority intervenes only to prevent harm.

5) Weak paternalism is when a person in authority intervenes only when there is mental deterioration of the other individual.

6) Paternalism by default is when otherwise capable, dependent person is indifferent to making reasoned decisions, so the person in authority must make the necessary decisions (Cicirelli 1989, 1992).

Personal variables and paternalism. A belief in paternalism is the acceptance of the right to act paternalistically for the welfare of another individual (Cicirelli 1989, 1992). It has been hypothesised that certain demographic variables and personality are connected to the belief in paternalism (Cicirelli 1989, 1990). Cicirelli (1989) did a study to test the reliability and validity of the final forms of the Respect for Autonomy and Paternalism scales and discussed some of its variables.

In one study fourty-six pairs of adult daughters and their elderly mothers were given a number of instruments to determine their personal traits and beliefs in paternalism: Cicirelli used The Paternalism Scale (Cicirelli, 1989), the Old People Scale developed by Kogan in 1961, and the Dogmatism Scale presented by Rokeach in 1960, a measure of affective feelings. He also did a demographic survey including six interview 
questions concerning the elderly mother's health status and the extent of caregiving received (Cicirelli, 1990).

Computations of the study showed moderate correlation between belief in paternalism, and negative attitudes toward older people and dogmatism, concerning both mothers and daughters. Again, the daughters' beliefs in paternalism were related to the mothers' age and daughters' educational levels and occupation. Daughters who had older mothers and lower educational and occupational level had stronger beliefs in paternalism, which may be related to a cultural context. Measures of the mothers' health status and level of received caregiving were not significantly related to their daughter's belief in paternalism (Cicirelli, 1990).

Appropriateness of paternalism. There are certain situations where paternalism seems to be appropriate (Árnason, 1993; Cicirelli 1990; Frímannsson, 1993). Paternalism can be ethically justified to prevent the risk of harm to a person due to severe incompetence. Árnason (1993) explains that paternalism threatens a person's autonomy and that a person in authority would need to show himself to be morally acceptable to make paternalistic decisions. Árnason (1993) and Frímannsson (1993) describe the following justifications for paternalistic decision making:

1.) children who do not have competence to make own decisions

2.) elderly that are mentally incapable of decision making

3.) developmentally and mentally disabled persons, i. e. persons who may not be able to make best choices concerning their well being. 
In her article (1985) Abramson described similar entities, and added two situations, i.e. when the consequences of an act are harmful and irreversible and when temporary interference with autonomy secures future freedom and autonomy.

\section{Instruments}

Mental Status screening. One of the most frequently used clinical procedures in screening of senile dementia and other cognitive dysfunction is The Mental Status Questionnaire (MSQ) designed and standardised by Kahn, R.L., Goldfarb, M.D. and others (1960). The MSQ was originally designed to measure the cognitive capacity of persons 65 years of age and older at their first admission to New York institutions for the elderly. The questionnaire consists of 10 questions that measure orientation and memory, and are scored as right or wrong with omissions scored as errors. The personal total scoring places each individual into one of 3 groups according to severity of cognitive dysfunction. Persons making 9 or 10 errors are considered having severe dementia, 3-8 errors as moderate and 0-2 as none or minimal dementia (Kahn, Goldfarb and others, 1960). The MSQ has the advantage of a short administration time. It is a concise and objective questionnaire that is very appropriate for rapid clinical and research screening.

Fillenbaum (1980) describes her research on comparison of the MSQ and the more recent Short Portable Mental Status Ouestionnaire (SPMSQ,) also a reliable and valid mental screening test developed in 1974. According to her results the two 10 item scales are equivalent in their capacity to identify organic brain dysfunction in older community-living adults. 
An Icelandic version of the MSQ is in common use, through the years, the questionnaire has been used as an initial screening tool for clinical and researches purposes. (Kolbeinsson \& Jónsson, 1993) .

The Respect for Autonomy and Paternalism Scales. A family member in a caregiving role has to deal with the personal, emotional, and financial care of the elderly family member. The caregiver's respect for the autonomy of the elderly family member is of great importance. It is also important to know when it is necessary to intervene and take over decisionmaking for that elderly person in order to prevent harm to the elder or to others. It is hypothesised that beliefs of autonomy/paternalism of caregivers are grounded in factors such as, relationships that already exist with the elderly person, including the values, ethical beliefs and personal trait of the caregivers (Cicirelli, 1989, 1992).

Cicirelli $(1989,1992)$ developed two separate scales to measure the beliefs of caregivers regarding autonomy and paternalism in care of the elderly. The purpose of these instruments was to assist practitioners to identify differences in beliefs of caregivers and care receivers in situations of caregiving where conflicts might arise. Results of these measures can provide useful information for counselling these persons to cooperate or work together in implementing autonomy. Information from results of these measures can also be of value in education of future caregivers.

Both the Respect for Autonomy Scale and Paternalism Scale (Cicirelli 1989, 1992) contain concise descriptions of situations involving caregiving decisions concerning health, financial and daily living situations. In the Autonomy Scale, items were written to represent the five types of autonomy: direct, consultant, joint, delegated 
and surrogate. Each item also described the elderly parent at a high or low levels of competence. In the Paternalism Scales, the items represent the six types of paternalism: direct, indirect, benevolent, moderate, weak and default. Each item also includes situations concerning health, finance and daily living with an elderly parent with high to low levels of competence.

Instrument development. In the developmental stages of these scales, 80 items concerning respect for autonomy and 80 items dealing with paternalism were pooled, reviewed and edited to 40 items each per scale. These scales were then administered to 10 adult children and 10 elderly parents for a total of 20 individuals. The interviewees were asked to critique the items for clarity. After the first administration of the scales, 30 items were selected as the best questions for each scale. The two 30 item scales were then tried out on 31 adult children and 39 elderly parents. Analysis for internal consistency, reliability, item total score correlations, and item discrimination were conducted. The results were satisfactory and slight modifications were made to complete the final scale. (See Appendix A for copies of the scales.)

The final form of the two scales was then tested using two samples: 81 elderly parents and 147 adult children from a midwestern city in the USA, with a population of 100,000. The questionnaires were administered in each individual's home in connection with an interview. The results of a factor analysis showed two distinct factors for autonomy, which Cicirelli identified as independent autonomy and shared autonomy. The independent autonomy factor is made up of the subcategories of direct and consultant autonomy. The shared autonomy factor contains joint, delegated and surrogate autonomy. The Paternalism Scale showed one factor, which included six types of paternalism: 
strong, indirect, default, benevolent, moderate, and weak. Intercorrelations were calculated between shared autonomy and the total paternalism scores, which showed moderate correlations.

Reliability. Internal consistency reliability scores (Cronbach's Alpha) were calculated for the five autonomy subtypes as well as the six paternalism subtypes and the total scale scores. In the Respect for Autonomy Scale, subscale reliability ranged from .50 to .73 for the adult child group and from .43 to .54 for the elderly parent group. Reliabilities for the total scale score were .78 for the adult child group and .76 for the elderly parents. Reliability for total autonomy was .78 for the adult child group and .76 for the elderly parent group. Reliability for the two factors of autonomy for adult children were .74 and .78 for the independent and shared autonomy scales, respectively and .70 and .74 for the elderly parent group. The reliability for the subscales and factor score is considered satisfactory for research on comparisons between groups (Cicirelli 1989, 1992).

Reliability for the six types of paternalism ranged from .67 to .84 for adult children and .48 to .76 for the elderly parents. Reliability for the total paternalism scores were .93 and .90 for adult children and elderly parents respectively. Results confirm a reliability that is satisfactory for the interpretation of individual scores as well as for group comparisons.

After 20 weeks, sixty randomly selected subjects were retested to determine testretest reliability. Test-retest correlation for the adult child group was .63 for independent autonomy, .52 for shared autonomy and .88 for total paternalism. For the elderly parent retest group, the test-retest correlations were .60 for independent autonomy .39 for shared 
autonomy and .49 for total paternalism scale score. All test-retest correlations were statistically significant, indicating considerable stability over a $41 / 2$ month interval. Cicirelli (1989) pointed out that scores for elderly parents showed less stability than those of the younger subjects on the total paternalism score as well as on the shared autonomy Score over a 20 weeks period without being able to explain the reason for this fact.

Validity. Cicirelli (1989) described the Respect for Autonomy and Paternalism scales as being "straight forward in nature" therefore they can be said to have face validity (Cicirelli, 1989, p.7). The Scales were also assumed to have content validity since the items represented in the scales defined types of autonomy and paternalism as well as three major domains of caregiving decision situations.

To establish criterion validity, Cicirelli compared the independent autonomy, shared autonomy, and paternalism scores with two scales: The Ethical Beliefs Situations Test (Cicirelli 1989, 1992) which he developed for the study and the Caregiving Practices Inventory (Cicirelli, 1989, 1993). On the Ethical Belief Situation Test, the situational autonomy scores, or who should make the decision, the elderly parent or adult child, were similar to the score of independent autonomy from the autonomy scale. Using the field test sample of 147 adult children of elderly parents. Cicirelli calculated independent autonomy with the correlation $.40(\mathrm{p}<.01)$ with the situational autonomy score. Paternalism was correlated $-.57(\mathrm{p}<.01)$ with situational autonomy . Using the field test sample of 81 parents, independent autonomy was correlated $.20(\mathrm{p}<.01)$ with situational autonomy. It was assumed that the situational autonomy score would be negatively correlated with the paternalism score. Thus evidence is provided for validity of the 
independent autonomy and paternalism scores, although it is weaker for the elderly parent group than for the younger generation (Cicirelli, 1989, 1992).

When comparing the Caregiving Practices Inventory, it was expected that increased number of decisions made by the adult children would be equated to the paternalism score and that the increased number of decisions made by the elderly parents be equated to the independent autonomy factor. The results showed low correlations but in the expected direction. Again using the field test samples, in the adult children group, paternalism was correlated .29 with the numbers of decisions made by the adult child and - .22 with the numbers of decisions made by the elderly parent. Independent autonomy was correlated .22 with the numbers of decisions made by the parent and -.20 with the number of decisions made by the adult child. Paternalism was correlated .23 with the number of decisions made by the adult child and -.35 with the number of decisions made by the elderly parent. Shared autonomy was correlated .28 with the number of decisions made jointly by parent and child (Cicirelli, 1989, 1992).

In order to test construct validity, the Respect for Autonomy and Paternalism scales were compared to other scales measuring various traits or attributes. It was hypothesised that persons with authoritarian personalities would be more apt to show authority to persons with weaker personality traits. Authoritarian persons were believed to have a greater paternalism score and lower scores on independent autonomy. To measure authoritarianism, The Balanced F-Scale presented by Cherry and Byrne in 1977, on which a low score proves more authoritarianism, was used to measure that concept. The correlations for the adult children was - .43 with paternalism and .24 with 
independent autonomy. The Correlations for the elderly parents between the F-Scale scores and paternalism were -.22 . All correlations were in the predicted direction.

It was also hypothesised that greater belief in paternalism would correlate with a greater concern for the parent's well-being, measured by the Filial Anxiety Scale developed by Cicirelli in 1988. The correlations were .24 with paternalism and .28 with shared autonomy. The greater the child's concern for the parent was related to greater participation in parental care and belief in paternalism (Cicirelli 1989, 1992).

Correlations were finally computed to find out if social desirability had significant impact on the responses to the Respect for Autonomy and Paternalism scales. The scores on these scales were correlated with the Marlow-Crowne Social Desirability Scale, (Crowne \& Marlow, 1960). For the elderly parent group social desirability was correlated .12 with independent autonomy, - .02 with shared autonomy, and .17 with paternalism. Whereas for the adult child group, social desirability was correlated - .01 with independent autonomy, -.01 with shared autonomy and .16 with paternalism. There is only a weak influence upon the answers of the two groups to the Respect for Autonomy Scale and Paternalism Scale (Cicirelli, 1989, 1992).

Diverse demographic variables were expected to correlate with beliefs in autonomy and paternalism. An adult child's age correlated .26 with paternalism and -.20 with independent autonomy, which indicates that the older the adult child the more paternalistic the beliefs. Whereas the parent age was correlated .22 with paternalism and .23 with independent autonomy. A lower educational level was also expected to be connected to greater paternalistic beliefs. This was built on a correlation of -.37 . It was also hypothesised that men would be more paternalistic than women. This was supported 
by a weak correlation of $-.13(\mathrm{p}<.10)$ between the child's gender and paternalism (Cicirelli, 1989, 1992).

\section{The Model of Human Occupation}

The Model of Human Occupation was developed by Kielhofner (1995) to provide an explanation of occupational behavior. The model is built on general systems theory and the original philosophical premises, set forth by the founders of the profession. The principles were strengthened by Reilly's model, where she redirected the emphasis from habit training and the work, play, rest continuum, to occupational roles. Occupational behaviors were originated in these occupational roles, and included various central themes, such as competency, which was described as the ability to "interact effectively with the environment" and to have the capability to handle situations or tasks (Levy, 1993). Reilly's occupational behavior model constitutes the basis of Kielhofners' model, where the emphasis is on motivation and the assumption, that because people need to explore and to be active, they can grow and change.

Kielhofner (1995) defines the term occupation as being the action or doing through which people occupy their physical and social world. It includes three general areas of occupational behavior: play, work and daily living tasks behavior that is filled with meaning. Thus human occupation can be defined as doing culturally meaningful things. The model of human occupation (Kielhofner, 1995), depicts the human being as an open system, which develops and changes through constant interaction with the environment. According to the model, the human system is composed of a hierarchy of three subsystems: volition, habituation, and performance. Volition, the highest 
subsystem, is responsible for the motivation to enact occupational behavior; it also comprises personal causation; a person's belief in his or her own skills and control; and values, which refer to a person's choices in occupation, built on earlier experiences. This subsystem addresses how occupational behavior is motivated. Its components include individuals' beliefs in autonomy, expectations of themselves and their environment, values, goals and interests. The volitional subsystem organizes the way individuals make and act out their choices, based upon their values and goals. This again enables individuals to explore and master their environment through their habituation and mindbrain-body performance subsystems, and to act upon their autonomous decisions. The desire for personal control and autonomous actions continues through every person's life into late adulthood (Kielhofner, 1995).

Habituation is a subsystem, which consists of two types of occupational behavior; roles, which are related to position in various groups; and habits that plan a person's behavior in concert with social and cultural norms. Family roles and relationships such as grandparent, mother, spouse and friend are sources of self-identity for the elderly. Relationships with adult children, grandchildren and friends may often be important sources of pleasure, which can be seen in reciprocal changes of affection, gifts and services. Older adults may often act as babysitters, housesitters, confidants and advisors and in turn as they become frail or chronically ill, their adult children may undertake the responsibility for their aging parents (Kielhofner, 1995). As people grow older, new habits may have to be formed to adjust to age related changes. Older persons may experience major changes in their roles, such as worker to retiree and spouse to widow. Habits developed through their lifespan in a stable environment may have to be changed 
according to changes in the environment or declines of individuals' capacity. However, it has to be emphasized that to keep up older individuals' functional performance and quality of life, habits become increasingly more important (Kielhofner, 1995).

The mind-brain-body performance subsystem is composed of three types of skills necessary to enact occupational behavior in daily life, these are: motor skills, process skills, communication/interaction skills (Kielhofner, 1995; Kielhofner and Barritt, 1998) . In late adulthood age related changes, that may diminish capacity, typically occur in the musculosceletal, neurological and cardiorespiratory systems of the individual. However, grave losses of ability may be prevented if the older person stays active, and in case of decline in capacity, its effects may be diminished by environmental adaptation or adaptation of the older persons' habits. (Kielhofner, 1995).

The individual's interaction with the environment is affected by the three subsystems. The human being is described as a system functioning in an environment which consists of culture, social groups, tasks and objects, which influence the person's performance in daily activities (Kielhofner, 1995). The environment influences the way people choose, plan and act out occupation, it either provides opportunities by giving certain freedom to choose and perform, or it presses for different types of behavior.

Environmental press, which includes demands on a person's upper capacity, tends to raise involvement, consideration and utmost performance. As a contrast, demands below capacity can create disinterest (Kielhofner, 1995). Culture shapes the environment, that is the values, customs, norms and beliefs of social groups. A culture is inherited through generations, and results in particular lifestyles. A person's values, sense of 
competence, roles, habits and interests are connected to that person's connection to a specific culture, or subculture, whether it is the home, neighborhood or other occupational behavioral settings (Kielhofner, 1995).

$\underline{\text { Self-Report }}$

The most common measurement strategy in personality research has been to obtain information directly from the individual under study. Self-report is concerned with obtaining information from the individual who is available to the person. It does not need either interpretation by a skilled examiner or the use of a criterion-based key. According to Moscowitz (1986). There is great ease in the use of self-report and it has been used to access a wide variety of attributes.

Traditionally self-reports have been collected on one occasion. Information is usually requested in written form, thus there are few changes in procedure at different points. Sometimes it may be necessary to interview individuals to elicit self-reports. Then careful training and monitoring of interviewers can be done to prevent possible biases, such as giving instructions on procedure, the effects of wording and body language (Moscowitz, 1986).

Errors that may be done by the respondent can be a major threat to validity of the self-report, since people's tendency to respond in a socially approved manner affect their responses. Thus, as stated by Moskowitz (1986), the self-report can be affected by the social desirability of the respondent, which again depends upon the respondent's particular personality characteristics and the particular questions that are used. People's 
inclination to agree without consideration of content is another factor affecting validity of the self-report. This bias can be reduced during the construction phase, by not keying a high proportion of items in the same direction, by using forced choice or by using certain kind of formats that reduce social desirability (Moskowitz, 1986).

Moscowitz also includes some steps that may be used to reduce threats to validity stemming from the respondent. The respondent should have the expectation of confidentiality and that the responses will be compared to other sources of information. To raise the validity, the respondent should get some practice in self-assessment prior to the actual data collection. He also implies that under conditions of self-focused attention, improved accuracy is found for reports about many topics, including reports about attitudes, cognition's and somatic states.

In 1990, Moskowitz reported his study on the validity of self-report and other measures of six different situations of friendliness and dominance based on independent observations in laboratory. In comparing data for men and women He noted that it appeared that men and women are able to provide accurate self-reports about different characteristics, and that there were no systematic tendency for men or women to rate themselves either high or low. Men gave more accurate self-assessments about dominance and women more accurate self-reports of friendliness. However, in his conclusion he states among other things, that there may be sex differences in the accuracy of self-report information that substantially affect the interpretation of empirical findings, in that both men and women were conforming to sex role expectancy (Moscowitz, 1990). 


\section{Chapter III}

\section{$\underline{\text { Research Procedures and Methodology }}$}

The succeeding procedures were carried out in order to assess Icelandic elderly individuals' perceptions of independent and shared autonomy and paternalism in caregiving of their age group. For that purpose Cicirelli's (1989) Respect for Autonomy and Paternalism Scales were used in order to measure the attitudes of the particular group. As Cicirelli (1990) stated, "At least in theory, the degree of dependency of the elderly parent (i.e., type and amount of help needed during caregiving) is related to paternalistic caregiving. Certainly this is true in many areas of medical care and social services. Thus, one would expect indicators of dependency to be important predictors of belief in paternalism. However, it may be that personal-social factors such as negative attitudes, dogmatism, and attachment, are equally important" (p. 459). Built upon this statement of Cicirelli, it is important to learn the attitudes of Icelandic elders toward autonomy and paternalism in care of elderly.

\section{Research Questions}

1. What are the attitudes and beliefs of Icelandic elderly individuals toward autonomy and paternalism in caregiving of the elderly? 
2. Are there differences in attitudes and beliefs of older persons living in senior housing complexes compared to those living in their own homes in the community?

\section{$\underline{\text { Research Design }}$}

The research was a descriptive study. The data were analyzed descriptively with frequencies and percentages for the characteristics of the sample of elderly Icelandic parents.

$\underline{\text { Subjects }}$

The subjects for this study were a convenience sample of elderly citizens living in their own homes in the community, and those living in senior housing complexes in the greater Reykjavik area. All participants were volunteers. The participants' names were not asked for, the questionnaires were identified by coding and results only reported as grouped data. All subjects were administered the Mental Status Questionnaire (MSQ) (Kahn and others, 1960) at the beginning of the questionnaire. No one was eliminated due to a score below 8 during the survey period in order to avoid singling out any particular individual. Human subjects approval was obtained through Florida International University's Human Subjects Committee, as well as the approval of the Icelandic Data Commission Committee.

Contact was made with the Elderly Citizens'Association in the greater Reykjavik area and permission granted to advertise the study on their center's notice board. Contact was also made with managers of two community citizen centers for the elderly and a senior housing complex in the greater Reykjavik area. Permission was received to put up 
advertisement on the study on their notice boards and leave flyers advertising the study. A description of the study, name and contact number of the researcher was included on the advertisement, as well as a specific time and place to meet with the researcher and to fill out the questionnaire. Staff members of the centers were informed about the study, including the inclusion and exclusion criteria in order to gain their assistance to recruit volunteers for the study.

\section{$\underline{\text { Inclusion }}$}

1. Subjects included in this study were elderly individuals (parents) 65 years and older, that had a living adult child, and resided in the community of greater Reykjavik area.

2 Individuals with scores of 8 or higher on the Mental Status Questionnaire (MSQ).

\section{Exclusion}

Subjects with the following characteristics were excluded from this study:

1. Subjects with dementia, brain injuries, mental retardation and other conditions affecting cognition.

2. Subjects who scored below 8 on the MSQ.

\section{Procedures}

The Respect for Autonomy and the Paternalism scales were used to measure elderly individuals' attitudes and beliefs toward autonomy and paternalism regarding care of the elderly (Cicirelli, 1989). The original survey instruments, including the demographic section, were developed in the United States of America. 
Adaptation of instruments. In order to be able to use the instruments in Iceland they had to be reviewed for face validity by five panel members in Iceland for the conceptualization of the questions and their relevance to Icelandic culture. A panel was composed of individuals from different backgrounds including occupational therapy, medicine, sociology, and social services for the elderly, who were proficient in written English.

Panel members were given a structured interview using specific questions regarding their conceptualization of autonomy and paternalism (see Appendix B). All panel members expressed understanding similar to these issues in the U.S. literature expressed by Cicirelli (1989). This indicated that their concepts seem to be compatible to those in the U.S. where the scales were developed. After their individual interviews, panel members reviewed the two instruments for appropriateness of concepts, situations and terminology for Icelandic subjects. In general the panel members felt the conceptualization of the US instruments was appropriate for use in Iceland.

After the panel review, the instruments were translated into Icelandic. These translated Icelandic versions of the instruments were then translated back into English by a separate translator. The original English version and the Icelandic versions that had been translated back into English were then compared to identify if the content and the meaning of the questions had remained the same after translation. Adjustments were made to the Icelandic versions untill they were comparable to the English version to ensure that the meaning in both the Icelandic and original versions were similar. Following the translations adjustments had to be made to terms used to describe the 
elderly parents' cognitive level. The wording to describe cognitive level with terms such as "of sound mind", "forgetful", "mentally confused", "not thinking clearly", and "senile" were not compatible with the original English version when translated back from Icelandic into English. Four specialists working in gerontology were given a list of the above mentioned English terms describing an elderly person's cognitive levels and were asked to provide an Icelandic word that would best describe each of the terms. The specialists, (two physicians, a nurse and an occupational therapist) reached an agreement for Icelandic terms, which were compatible to the English terms and substituted. The Icelandic terms were then translated back to English. This second version translated from Icelandic was compared to the original English version and the instruments were found to be comparable.

Apart from changes in definitions of specific terms regarding mental impairment following adjustments were made to the Respect for Autonomy scale:

Question \# 2: Translation of the term "emotionally unstable" into Icelandic proved problematic for all persons asked, as no appropriate Icelandic term seemed to convey the same meaning. The difficulty was in finding a term that expressed the "emotional" part of the term "emotionally unstable". After discussion with panel members it was suspected that Icelanders did not have many terms to describe their "emotional status", as this was not openly discussed. A term that has similar meaning as the English term was eventually chosen after an intense discussion, but the meaning is not exactly the same. This was not considered possible in light of cultural differences. 
Question \# 6: In translating the term "driving across the country" into Icelandic, the wording of this term had to be changed completely to reflect the same meaning in the Icelandic environment. In Iceland "driving across the country" would specifically mean driving through the barren highlands of the country. A broader term had to be used to convey the same meaning as in English. In Icelandic the wording that was used means literally "to drive long distances into the countryside".

Changes had also to be made to the Paternalism Scale. Question \#16; the direct Icelandic translation of the word "insist" is "demand". These terms are used interchangeably in Icelandic, unlike in English, where they have different meanings. A different Icelandic wording had to be used to convey the same meaning as in English. Question \# 24: In Icelandic the terms "routine" and "habit" are used interchangeably, they have exactly the same meaning, unlike in English. Therefore in the Icelandic version of question \# 24 the word "habit" is used for the English term "routine".

A similar procedure of translation and comparing of the original English version and translation translated from Icelandic into English was also used for the demographic questionnaire that proceeded the two instruments in the survey. Cicirelli had used the original demographic questionnaire when in his study examining older parents' beliefs in caregiving of the elderly. Some questions were altered or omitted since they were found inappropriate for the surveyed Icelandic subjects. Other questions were added based on literature pertaining to previous studies of attitudes and beliefs.

The following questions from the U.S. version were omitted: The subjects'anonymity was respected by omitting questions on name, address, city, state zip 
code and telephone number. Four questions, two on ethnicity and two on language spoken were considered unnecessary, as the percentage of elderly persons of foreign origin in the society is too small to affect the study.

The following questions were adapted: A question on religious affiliation was modified and limited to three options, as the majority of Icelanders belong to the Lutheran religion. Questions regarding the parent's and adult child's education were modified to suit Icelandic educational categories. Grading of questions concerning the subjects' health were cut down to four, i.e., "excellent", "good", "not so good", "poor", and grading of the question about living and distance between parent-child, were altered and cut down to 5 possibilities of different time lengths. Finally, the age a person is referred to as elderly was altered to 65 years instead of 60 years since elderly Icelanders may already receive old age benefits from specific funds at that age .

The following questions were added to the Icelandic demographic questionnaire for the purpose of describing perceptions of their living arrangements, occupational performance abilities and financial status as they were considered important factors of well-being: Questions 13, 14, 15, 16, 17, 18, 19, 20, 21. See Appendix C.

$\underline{\text { Pilot study. A pilot study of the demographic data sheet and instruments used was }}$ conducted on six elderly individuals. After completion of the survey the six individuals were interviewed to determine if there were any problems with the structure, wording or style. A final version of the instruments was used with the subjects.

The pilot study revealed some minor problems with checking possibilities of question number 18 , where the answer "my previous housing was inconvenient" was 
added to the checking possibilities. A statististician had to be consulted in order to adapt the Likert-scale measures of the instruments, since subjects reported difficulties distinguishing between the concepts used in the English version. Grading of the Likert Scale was then adapted to suit wordings and understanding of the Icelandic culture. Using the terms "strongly disagree", "slightly disagree", "undecided", "slightly agree", and "strongly agree" to replace the original terms.

The subjects commented on the similarities of the questions of the instruments, and their tendencies to look back on previously answered questions. All subjects found the survey very lengthy and time consuming. The time spent for filling out the questionnaires ranged from 50 minutes to an hour and 20 minutes. After the pilot study had been completed and changes applied, the demographic questionnaire and the two instruments, The Respect for Autonomy and Paternalism Scales (see Appendix A) was utilized with the Icelandic elderly subjects.

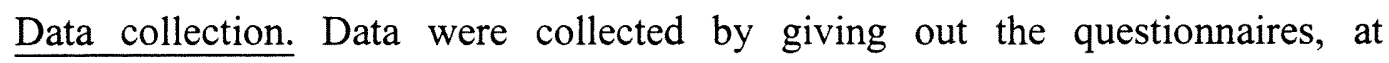
predetermined group meetings. At the meetings a short protocol of instructions was read out at the beginning of meeting to improve reliability. The subjects were informed before-hand, that the questionnaire would take about an hour to complete and it was explaned how important it was that each subject answer all the questions, because incomplete questionnaires could not be used in the study (See Appendix D). 
$\underline{\text { Instruments }}$

The Respect for Autonomy Scale and the Paternalism Scale were used to measure the elderly individuals' attitudes toward autonomy and paternalism in caregiving of their age group (Cicirelli, 1989). Both the Respect for Autonomy Scale and Paternalism Scale items are scored on a 5 point Likert scale, ranging from strongly disagree (1) to strongly agree (5).

The Respect for Autonomy Scale includes the five types of autonomy: direct autonomy, consultant autonomy, joint autonomy, delegated autonomy and surrogate autonomy, each have a score range from 6 points to 30 points. Subscores were calculated as follows: direct autonomy (sum of items $1,6,11,16,21,26$ ), consultant autonomy (sum of items 4, 9, 14, 19, 24, 29), joint autonomy (sum of items 2, 7, 12, 17, 22, 27), delegated autonomy (sum of items $5,10,15,20,25,30$ ) and surrogate autonomy (sum of items $3,8,13,18,23,28)$. The score range for the Autonomy Scale is $30-150$ points. Higher scores represent greater respect for autonomy of a given type. Cicirelli (1989) further grouped direct autonomy and consultant autonomy into one factor, named independent autonomy (sum of scores for items 1, 4, 6, 9, 11, 14, 16, 19, 21, 24, 26, 29); and joint autonomy, delegated autonomy and surrogate autonomy into another factor, named shared autonomy (sum of items $2,3,5,7,8,10,12,13,15,17,18,20,22,23,25$, 27, 28, 30). The score range for Independent Autonomy is $12-60$ points and $18-90$ points for shared autonomy.

The Paternalism Scale contains six types of paternalism. These are strong paternalism, indirect paternalism, benevolent paternalism, moderate paternalism, weak 
paternalism and default paternalism. Subscores for the six types are: strong paternalism (sum of scores for items 1, 14, 19,26), indirect paternalism (sum of scores for items 2, 7, $15,25,30$ ), moderate paternalism (sum of scores for items $5,10,18,22,29$ ), weak paternalism (sum of scores for items $3,8,13,20,24$ ) and default paternalism (sum of scores for items $6,11,16,27,28)$. These six types are then grouped as one factor being total paternalism (sum of scores for items 1 through 30). The score range for each of the six subscales of paternalism is $5-25$ points and the score range for the total paternalism Scale is $30-150$ points. A high score represents a higher paternalism of the given type (Cicirelli, 1989).

There are three types of caregiving situations for both the Respect for Autonomy Scale and the Paternalism Scale. These three situations were computed as follows: health (sum of items 1, 4, 7, 10,13,16, 19, 22, 25, 28), finance (sum of items 2, 5, 8, 11, 14, 17, $20,23,26,29$ ), and activities of daily living (sum of items $3,6,9,12,15,18,21,24,27$, 30). When either the Respect for Autonomy Scale or the Paternalism Scale is paired with any of the three caregiving situations, the score range is from $10-50$ points. Each of the three types of caregiving situations matched with each subtype of either the Respect for Autonomy Scale or the Paternalism Scale has a score range of $2-10$ points.

The elderly parent may be of "sound mind", or "confused mind" on either the Respect for Autonomy Scale or the Paternalism Scale. On the Respect for Autonomy Scale, the elderly of "sound mind" (sum of items 1, 3, 4, 6, 7, 8, 9, 11, 14, 17, 19, 20, 22, $23,25,27,28,30$ ) has a range of 18 - 90 points, while the elderly parent of "confused mind" (sum of items $2,5,10,12,13,15,16,18,21,24,26,29)$ has a score of $12-60$ 
points. On the Paternalism Scale, the "sound mind" elderly parent (sum of items 1, 2, 3, $4,5,6,7,9,10,11,12,14,15,16,17,18,19,21,22,23,25,26,27,28,29,30)$, has a score range of 26 - 130 points, and the elderly parent with "confused mind" (sum of scores for items $8,13,20,24$ ) has a range of $4-20$ points.

$\underline{\text { Statistical Analysis }}$

Descriptive statistics, such as scale means, score means, standard deviations, frequencies and percentages were used to describe the attitudes and beliefs of Icelandic elderly individuals toward autonomy and paternalism in relation to care of the elderly. Ttests and chi-square computations were used to test for differences toward autonomy and paternalism between elderly living in senior housing complexes and those living in their homes in the community.

All data analysis was carried out using The Statistical Package for the Social Sciences (SPSS).

\section{Limitations of the Study}

1. The results of convenience sampling data can only be generalized to the sample of elderly in the greater Reykjavik area.

2. Unknown bias may be present when using volunteers.

3. Small sample size. 


\section{Chapter IV}

\section{$\underline{\text { Results }}$}

The results of the data collected in this study are presented in this chapter. The research questions to be examined are (1) what are the attitudes and beliefs of Icelandic elderly individuals toward autonomy and paternalism in caregiving of the elderly? (2) Are there differences in the attitudes and beliefs toward autonomy and paternalism of older persons living in senior housing complexes compared to those living in their homes in the community?

\section{$\underline{\text { Demographic Data }}$}

A total of seventy-one surveys were distributed to elderly citizens in the greater Reykjavik area. Of those, three did not meet the predetermined inclusion-exclusion criteria in that one was not a parent and two did not answer the mental status questionnaire. Two subjects returned their surveys unanswered feeling intimidated by the length of the survey questionnaire. Nine surveys had to be excluded due to incomplete answers on the Autonomy and Paternalism Scales. Therefore, a total of 57 subjects (or $80.28 \%$ ) were included in the study.

Based on the data of 57 subjects, there were 18 males (31.6\%) and $37(64.9 \%)$ females with the gender of two subjects unanswered (Table 1). Their age ranged from 65 to 85 years, with a mean age of 74.19 and a standard deviation of 5.38. Marital status data revealed that $27(47.4 \%)$ were widowed, $22(38.6 \%)$ were married, four $(7 \%)$ were 
single, two $(3.5 \%)$ were living in a married like relationship and two $(3.5 \%)$ were divorced.

Table 1

Personal Characteristics of the Respondents

\begin{tabular}{lll} 
Variables & Frequency & Percent \\
\hline
\end{tabular}

\section{Gender}

Male

Female

Total

Age

$$
\begin{aligned}
& 65-74 \\
& 75-84 \\
& 85-
\end{aligned}
$$

Marital Status

Single

Married

Widowed

Total
18

37

55

33

23

1

57
32.7

67.3

100.0
58.1

40.1

1.8

100.0

\section{Physical Health}

Excellent

Good

Not good - poor

Total

\section{Emotional Health}

Excellent

$$
6
$$

10.5

24

27

57

42.1

47.4

100.0

Good

Not good - poor

Total

Intellectual Functioning

Excellent
Good
Not good - poor

Total

25

20

12

57

43.86

35.09

21.05

100.0

35

61.4

12

10

57

21.1

17.5

100.0

24

43.6

25

45.5

6

10.9

55 100.0

Table continues 
Table 1 (continued)

Variables

Frequency

Percent

Education

Elementary to beyond junior high

49

89.1

High school dipl. and beyond

10.9

Total

57

100.0

Occupational Status

Retired, not looking for job

Retired, looking for work

64.2

Working part-time or full-time

Housekeeping, no other job

Disabled

Total

53

100.0

\section{Living Arrangements}

Own home

36.8

Senior Housing

\section{Total}

57

100.0

Reason for Choosing Senior Housing

To lower cost of housing 50.0

To be free of maintainance

To get security and support

In search for tranquility

To be in company of peers

Previous housing inconvenient

12

52.8

Preferred Living Arrangement

98.2

Prefer to Live in Current Home

Distance from adult child

Within walking distance

Less than $30 \mathrm{~min}$. drive one way

30-60 minutes drive one way

More than one hour one way 
Fifty-two subjects reported being of Lutheran religious affiliation (91.2\%), three (5.3\%) reported no religious affiliation and two (3.5\%) did not answer the question.

Regarding the respondents' education, 49 subjects $(85.9 \%)$ reported education of less than a high school diploma: thirteen $(22.8 \%)$ respondents had elementary or less schooling, nine (15.8\%) finished junior high school, seventeen $(29.8 \%)$ subjects had finished part of high school and ten subjects (17.5\%) indicated trade schooling or other beyond junior high. One subject (1.8\%) had a high school diploma, another had some university level education, three (5.5\%) had finished their 3 year diploma at the university level, one $(1.8 \%)$ had a B.Sc. degree and three $(5.5 \%)$ did not answer the question.

For occupational status, $34(59.6 \%)$ reported they were retired and not looking for jobs, eight $(14.0 \%)$ were retired but working part-time, one $(1.8 \%)$ reported being retired and looking for a job, three $(5.3 \%)$ were working part time and three $(5.3 \%)$ worked full time. Housekeeping was the main occupation of three subjects, and one reported being disabled. Six subjects (7.0\%) failed to answer the question.

The majority of the subjects reported to be in either excellent $(n=25,43.86 \%)$ or in good physical health $(n=20,35.09 \%)$, whereas twelve subjects $(20.05 \%)$ described their health as being not so good or poor. Answering the question about emotional health, $35(61.4 \%)$ reported their emotional health as excellent, twelve $(21.1 \%)$ reported good health, whereas eight (14.0\%) admitted to being in not so good emotional health and two $(3.5 \%)$ felt they were in poor emotional state. When asked about their intellectual functioning, $24(42.1 \%)$ subjects answered that they were in excellent functioning status, 
$25(43.9 \%)$ reported good status, and six (10.5\%) subjects were in not so good status and two did not report regarding their intellectual functioning.

When the elderly subjects were asked about their housekeeping abilities, 37 (64.9\%) reported being independent, while 19 (33.3\%) admitted that they needed some assistance and one subject omitted answering the question. Of these 19 subjects, one needed assistance getting to places, two needed help buying food and clothing and six reported needing assistance with hot cooked meal preparation. Sixteen subjects needed help with heavy housework; three reported needing assistance with money management while four reported the need of assistance with medicine management.

Only one person reported needing assistance regarding personal care and 11 $(22.0 \%)$ indicated the use of helping aids.

In response to the question if the subject received help from other than the adult child, $13(22.8 \%)$ subjects indicated that they received no help, $17(29.8 \%)$ reported the help of a spouse, $22(38.6 \%)$ reported the help of another adult child, five $(8.8 \%)$ subjects reported the help of other relatives, and two the help of friends. Two subjects indicated the help of a home nurse, six responded that they received the help of a home-helper while four subjects failed to answer the question.

In response to the question about weekly helping hours received, thirty-two (56.1\%) responded they received no help, 17 subjects (29.8\%) indicated 1-3 hours of help per week, while two (3.5\%) reported $4-6$ hours per week and two failed to answer the question.

Fifty-four elders $(94.7 \%)$ reported that their present type of accommodation was their preferred choice, whereas one subject said no and three did not give an answer to 
the question. To the question, would they prefer to live in their home in the community until their dying day, provided they would get necessary support from support services, $42(73.7 \%)$ responded positively, seven (12.3\%) responded negatively and eight $(14 \%)$ did not answer the question.

In response to questions concerning housing and living arrangements, 36 subjects $(63.2 \%)$ stated that they live in senior housing complexes and $21(36.8 \%)$ live in their own homes in the community. When subjects living in senior housing complexes were asked why they had chosen this type of living arrangement, 19 subjects reported that it was to be free of maintenance and gardening, 19 indicated that their previous housing was inconvenient, 18 indicated that it was to lower the cost of housing, 12 stated that they wanted to be in the company of their peers, 11 subjects answered that they were in search for security and support and seven indicated tranquility as a reason for their choice.

In describing how they managed financially, the majority of the subjects indicated that they were comfortably well off. Nineteen $(33.3 \%)$ respondents reported that they could always afford "little luxuries" in their lives, 17 (29.8\%) reported that they could often afford the "little luxuries". Ten subjects (17.5\%) indicated that they were sometimes able to afford these "little luxuries", while only five (8.8\%) stated they could rarely afford those "little luxuries". Six subjects did not answer the question.

When asked what their personal income consisted of, 7 (12.3\%) subjects reported a regular salary as their main source of income, $42(73.7 \%)$ subjects reported receiving old age pensions, $48(84.2 \%)$ of the subjects received superannuation (pensions from special fund), $25(43.9 \%)$ received low income support payment and $16(28.1 \%)$ indicated that they received additional low income support payments. One subject 
reported a disability pension as a source of income and two subjects indicated other as sources of income, such as stocks, bonds and other benefits.

In answer to the question about distance between subject's and adult child's habitation, the majority of subjects $(87.7 \%)$ live near their adult children: $18(31.6 \%)$ respondents live within walking distance and 32 (56.1\%) live less than 30 minutes drive one way from their adult child. Two subjects reported living 30 minutes to an hour's drive one way to the adult child and three subjects indicated more than one hour's drive to the adult child. Two subjects gave no answer to the question.

In reporting information about the adult caregiving child, the subjects indicated that $15(26.3 \%)$ of the adult children were males and $34(59.6 \%)$ were females (Table 2$)$. There was no information about gender from eight subjects. The age of the adult children ranged from 27 years to 63 years, with a mean age of 44.76 years and standard deviation of 7.98. Seven subjects failed to report as to the age of their adult children. Forty-one (71.9\%), of the adult children were married, three were single, two were living in a married like relationship, five were separated or divorced, and one adult child was widowed. Six subjects did not respond.

Although four elderly subjects failed to answer the question concerning education of their caregivers, the elders reported that the majority of the adult children had a university level education. Six (10.5\%) of the adult children had a Masters or a Doctoral Degree, 10 (17.5\%) had Bachelors degrees, seven (12.3\%) had finished a 3-year Diploma at the university level, eight (14.0\%) started but did not finish their university education and six $(10.5 \%)$ had finished a high school diploma. A total of 16 adult children had less than high school diploma level education, six (10.5\%) adult children had finished trade 
school or other education beyond junior high school, seven $(12.3 \%)$ had completed some senior high school and three adult children had finished junior high school.

To the question about the adult child's occupation the elderly subjects described that the majority of the adult children $(n=34,59.6 \%)$ were working full time, six $(10.5 \%)$ were working part time and five $(8.8 \%)$ had housekeeping as their main occupation. Three subjects reported other occupations and nine subjects did not answer the question (See Table 2). 
Table 2

Personal Characteristics of the Adult Children

Variables

Frequency

Percent

Gender

Male

Female

15

30.6

34

69.4

Total

49

100.0

Age

$$
\begin{aligned}
& 27-39 \\
& 40-49 \\
& 50-63
\end{aligned}
$$

14

28.0

25

50.0

11

22.0

Total

50

100.0

Marital Status

Single

3

5.9

Married

43

84.3

Separated -divorced

5

9.8

Total

51

100.0

\section{Education}

Elementary to beyond junior high

16

30.2

High school dipoma and beyond

37

69.8

Total

53

100.0

\section{Occupational Status}

Working part-time

$\begin{array}{rr}6 & 12.5 \\ 34 & 70.8 \\ 5 & 10.4 \\ 3 & 6.3 \\ 48 & 100.0\end{array}$

Total

48

100.0 
The Respect for Autonomy Scale and the Paternalism Scale Scores

To answer research question one, scale means $(\underline{M})$, score means $(\mathrm{m})$, standard deviation (SD), and score ranges were calculated for subjects' responses for the Respect for Autonomy and Paternalism scales as well as for the subtypes. The scale means are means of the sums of the items composing the subtype or factor. The score means are the scale means transformed back to five point Likert type scale which ranges from one to five points. Results for the Autonomy Scale are presented in Table 3, and results from the Paternalism Scale are presented in Table 4.

The Respect for Autonomy Scale Scores. The potential score range on the Respect for Autonomy Scale (RAS) is from 30-150 points. Subject scores on the RAS, ranged from $69-150$ points. The mean score was 119.71 , and with a standard deviation of 17.97 , suggesting that the respondents were more in agreement than disagreement with autonomous statements (See Table 3).

The potential score range for the factor of independent autonomy is $12-60$ points. The actual scores of the respondents for independent autonomy ranged from 24-60 points with a scale mean of 43.40 , and a standard deviation of 8.46 . The potential score range for the factor of shared autonomy is $18-90$ points. The actual range was $45-90$ points with a scale mean of 75.71 and a standard deviation of 11.91. As with the overall RAS, the factors of independent and shared autonomy revealed more subject agreement than disagreement with autonomous statements although agreement on the independent autonomy was more undecided. The specific score means $(\mathrm{m})$ revealed more agreement for shared autonomy $(m=4.21)$ than for independent autonomy $(m=3.62)$. 
Table 3

$\underline{\text { Respect for Autonomy Scale Scores for Icelandic Elderly }(\mathrm{n}=57)}$

\begin{tabular}{lrrrrr}
\hline Variable & $\mathbf{n}$ & Range & M & SD & m \\
\hline TOTAL AUTONOMY & 52 & $30-150$ & 119.71 & 17.97 & 3.99 \\
INDEPENDENT AUTONOMY & 57 & $12-60$ & 43.40 & 8.46 & 3.62 \\
SHARED AUTONOMY & 51 & $18-90$ & 75.71 & 11.91 & 4.21 \\
Direct autonomy & 54 & $6-30$ & 19.06 & 5.30 & 3.18 \\
Consultant autonomy & 53 & $6-30$ & 25.32 & 4.17 & 4.22 \\
Joint autonomy & 54 & $6-30$ & 23.07 & 5.68 & 3.85 \\
Delegated autonomy & 55 & $6-30$ & 26.33 & 3.59 & 4.39 \\
Surrogate autonomy & 53 & $6-30$ & 25.92 & 3.94 & 4.32 \\
CAREGIVING SITUATIONS & & & & & \\
Health & 47 & $10-50$ & 40.43 & 6.66 & 4.04 \\
Financial & 48 & $10-50$ & 40.19 & 6.99 & 4.02 \\
Daily living & 45 & $10-50$ & 40.64 & 6.88 & 4.06 \\
ELDERLY PARENT COMPETENCE & & & & \\
Sound mind & 52 & $18-90$ & 72.46 & 12.27 & 4.03 \\
Confused mind & 54 & $12-60$ & 47.04 & 7.07 & 3.92 \\
\hline Note. & & & & &
\end{tabular}

Note.

Scores correspond to a Likert scale with $1 .=$ strongly disagree, $2 .=$ slightly disagree 3.= undecided, $4 .=$ slightly agree, $5 .=$ strongly agree

$\underline{\mathrm{M}}=$ Scale mean based on total $\mathrm{m}=$ Score mean from $1-5$

In reviewing the score means (m) for the five subtypes, the respondents agreed most strongly with delegated autonomy $(m=4.39)$ and consultant autonomy $(m=4.22)$, and least with direct autonomy $(\mathrm{m}=3.18)$. Although all score means were in agreement 
with autonomous decision making, the elderly were undecided concerning direct autonomy, where the elderly decides by him or herself. Score means (m) for caregiving situations and elderly parent competence indicated a strong agreement with autonomy, with strongest agreement on caregiving in daily living situations $(m=4.06)$, and least agreement with caregiving with less competent elders $(\mathrm{m}=3.92)$.

The Paternalism Scale Scores. The potential score range on The Paternalism Scale is $30-150$ points. The subjects' scores ranged from a minimum of 44 to a maximum of 150 , indicating greater variability in scores on the Paternalism Scale than on the Autonomy Scale. As shown in Table 4, the scale mean $(\underline{M})$ was 102.58 , with a standard deviation of 23.38 suggesting that the subjects were a little undecided in their beliefs in paternalism but agreed slightly with paternalistic beliefs.

The score mean for Total Paternalism $(m=3.41)$ suggests that the respondents agreed slightly with paternalistic beliefs, a suggestion that is supported by subtypes score means. Of the six paternalism subtypes, subjects agreed less with situations involving indirect paternalism $(\mathrm{m}=2.98)$ indicating that the respondents are slightly against the use of deception or subtle manipulation by another person intervening in decision making. Interestingly, the elderly seemed to agree most with situations involving default paternalism $(\mathrm{m}=3.80)$, which indicates that the subjects are in agreement with decision making by another person, when an otherwise competent, dependent person is indifferent to making the decisions needed. Of the various caregiving situations, subjects indicated similar paternalistic beliefs. Their scores are slightly above neutral indicating a slight inclination toward paternalism. 
Table 4

Paternalism Scale Scores for Icelandic Elderly $(n=57)$

\begin{tabular}{lrrrrr}
\hline Variable & $\mathbf{n}$ & Range & \multicolumn{1}{l}{ M } & \multicolumn{1}{l}{ SD } & \multicolumn{1}{l}{ m } \\
\hline TOTAL PATERNALISM & 43 & $30-150$ & 102.58 & 23.38 & 3.41 \\
Strong paternalism & 52 & $5-25$ & 17.90 & 4.96 & 3.58 \\
Indirect paternalism & 53 & $5-25$ & 14.89 & 5.41 & 2.98 \\
Benevolent paternalism & 54 & $5-25$ & 17.30 & 4.84 & 3.46 \\
Moderate paternalism & 52 & $5-25$ & 18.81 & 3.54 & 3.76 \\
Weak paternalism & 52 & $5-25$ & 17.06 & 4.59 & 3.41 \\
Default paternalism & 54 & $5-25$ & 19.02 & 4.35 & 3.80 \\
CAREGIVING SITUATIONS & & & & & \\
Health & 56 & $10-50$ & 35.08 & 7.69 & 3.50 \\
Financial & 56 & $10-50$ & 34.91 & 8.36 & 3.49 \\
$\begin{array}{l}\text { Daily } \\
\text { living }\end{array}$ & 56 & $10-50$ & 34.16 & 8.61 & 3.42 \\
ELDERLY PARENT COMPETENCE & & & & & \\
$\begin{array}{l}\text { Sound } \\
\text { mind }\end{array}$ & 55 & $26-130$ & 90.38 & 19.82 & 3.48 \\
Confused mind & 57 & $4-20$ & 14.18 & 3.70 & 3.55 \\
\hline$\quad$ Note: & & & & & \\
\hline
\end{tabular}

Note:

Scores correspond to a Likert scale with $1=$ strongly disagree, 2 = slightly disagree $3=$ undecided, $4=$ slightly agree, $5=$ strongly agree

$\underline{M}=$ Scale mean based on total

$\overline{\mathrm{m}}=$ Score mean from $1-5$ 
$\underline{\text { Reliability for the Autonomy and Paternalism Scale }}$

Cronbach's alpha coefficient was used to determine the internal consistency reliabilities for the Respect for Autonomy Scale, its two factors, and five subtypes, and the Paternalism Scale. The results were compared to the elderly parent sample $(n=81)$ from the original reliability study by Cicirelli (1989). The minimal acceptance level for reliability was set at . 70 and above using Cronbach's alpha coefficient. Hair and others (1992) reported this level of reliability as currently acceptable.

As shown in Table 5, The Icelandic sample generally had higher reliability on all variables than did the Cicirelli sample. The total autonomy coefficient for the sample of Icelandic elderly signified reliability .90 for the 30 items on the scale and .89 for the shared autonomy factor while Cicirelli's sample was in the desired range, .76 for total autonomy and .74 for the shared autonomy factor. Reliability for the Icelandic elderly sample (.73) and Cicirelli's elderly sample (.70) were within the desired range for the factor independent autonomy. Reliability for the joint autonomy factor was in the desired range for the Icelandic sample (.79), but fell far below the desired range for Cicirelli's sample (.43). The remaining autonomy subscales: direct autonomy, consultant autonomy, delegated autonomy and surrogated autonomy fell below the desired reliability coefficient range for both samples, although only slightly less for the Icelandic sample on the delegated (.69) and surrogate (.66) subtypes.

As displayed in Table 5, reliability for the Total Paternalism score for the Icelandic elderly sample was higher (.93) than for Cicirelli's elderly sample (.90). 
Table 5

Reliability for the Respect for Autonomy and Paternalism Scales

\begin{tabular}{|c|c|c|c|c|}
\hline Variable & $\begin{array}{l}\text { No. of } \\
\text { items }\end{array}$ & $\mathbf{n}$ & $\begin{array}{c}\begin{array}{c}\text { Icelandic } \\
\text { Elderly }\end{array} \\
\text { alpha }\end{array}$ & $\begin{array}{c}\begin{array}{c}\text { Cicirelli's Elderly } \\
(n=81)\end{array} \\
\text { alpha }\end{array}$ \\
\hline TOTAL AUTONOMY & 30 & 41 & $.90^{*}$ & $.76^{*}$ \\
\hline INDEPENDENT AUTONOMY & 12 & 41 & $.73 *$ & $.70^{*}$ \\
\hline SHARED AUTONOMY & 18 & 41 & $.89 *$ & $.74 *$ \\
\hline Direct Autonomy & 6 & 41 & .55 & .52 \\
\hline Consultant Autonomy & 6 & 41 & .64 & .54 \\
\hline Joint Autonomy & 6 & 41 & $.79 *$ & .43 \\
\hline Delegated Autonomy & 6 & 41 & .69 & .51 \\
\hline Surrogate Autonomy & 6 & 41 & .66 & .51 \\
\hline TOTAL PATERNALISM & 30 & 43 & $.93 *$ & $.90^{*}$ \\
\hline Strong Paternalism & 5 & 43 & $.80^{*}$ & $.76^{*}$ \\
\hline Indirect Paternalism & 5 & 43 & $.83 *$ & $.70^{*}$ \\
\hline Benevolent Paternalism & 5 & 43 & $.74 *$ & $.76^{*}$ \\
\hline Moderate Paternalism & 5 & 43 & .58 & .48 \\
\hline Weak Paternalism & 5 & 43 & .69 & .66 \\
\hline Default Paternalism & 5 & 43 & $.72 *$ & .64 \\
\hline
\end{tabular}


Table 6

$\underline{\text { Reliability for Autonomy and Paternalism in Caregiving Situations }}$

\begin{tabular}{llll}
\hline Variable & No. of & & Icelandic \\
items & & Elderly \\
\cline { 3 - 3 } & & $\mathbf{n}$ & alpha \\
\hline
\end{tabular}

AUTONOMY IN

CAREGIVING SITUATIONS

Health

$10 \quad 41 \quad .74 *$

Financial

$10 \quad 41 \quad .76^{*}$

Daily Living

$10 \quad 41 \quad .75 *$

ELDERLY PARENT COMPETENCE

Sound Mind

18

41

$.87 *$

Confused Mind

12

41

$.74 *$

PATERNALISM IN

CAREGIVING SITUATIONS

Health

10

43

$.79 *$

Financial

10

43

$.83 *$

Daily Living

10

43

$.83 *$

\section{ELDERLY PARENT COMPETENCE}

Sound Mind

\section{6}

43

$.92 *$

Confused Mind

$4 \quad 43 \quad .64$

* signifies reliability coefficient in desired range of .70 and above (Cronbach's Alpha)

$\mathrm{n}=$ number of respondents from the greater Reykjavik area

The Icelandic elderly sample had reliability scores ranging from .58 to .83 for the paternalism subscales, with moderate and weak paternalism falling below the desired range. Reliability for the respect for autonomy and paternalism in caregiving situations 
and in elderly parent competence ranged from .64 to .92 , (See Table 6) and tended to be high or in the desired range for all situations except for paternalism with elders of "confused mind".

Differences in Scores Between Two Groups of Community Living Elderly

In order to answer the second research question, the group of respondents was divided into two groups: elderly living in their own homes $(n=21)$ and elderly living in senior housing complexes $(n=36)$. To explore if there were significant differences between the two groups of elderly concerned t-tests were run (See Table 7). Results confirmed several differences. Senior housing respondents were older $(\mathrm{p}<.001)$ and in poorer physical $(\mathrm{p}=.013)$, emotional $(\mathrm{p}=.037)$ and intellectual health $(\mathrm{p}=.006)$, and the ages of their adult children were older $(p=.021)$.

Chi square tests were calculated on categorical personal characteristics by type of housing in order to establish if there were significant differences between respondents living in their own homes from those living in senior housing complexes (See Table 8). 
Table 7

Significant Differences in Characteristics of Respondents by Housing

\begin{tabular}{|c|c|c|c|c|c|c|c|c|}
\hline \multirow[b]{2}{*}{ Variable } & \multicolumn{3}{|c|}{ Own Home } & \multirow[b]{2}{*}{$\mathbf{n}$} & \multicolumn{4}{|c|}{ Senior Housing } \\
\hline & $\mathbf{n}$ & $\underline{\mathbf{M}}$ & SD & & $\underline{\mathbf{M}}$ & $\overline{\text { SD }}$ & t-Value & P -Value \\
\hline Age & 21 & 70.67 & 3.57 & 36 & 76.25 & 5.22 & -4.34 & $.000^{*}$ \\
\hline Physical health & 21 & 1.38 & .74 & 36 & 2.08 & .94 & -2.94 & $.013^{*}$ \\
\hline Emotional health & 21 & 1.29 & .717 & 36 & 1.78 & .898 & -2.14 & $.037 *$ \\
\hline Intellectional funct. & 20 & 1.35 & .59 & 35 & 1.86 & .648 & -2.89 & $.006^{*}$ \\
\hline Age of adult child & 18 & 41.33 & 7.20 & 32 & 46.69 & 7.83 & -2.38 & $.021 *$ \\
\hline
\end{tabular}

Note. $\quad *=$ Level of significance $p=0.5$ or less

Comparisons were made between the two groups by gender, marital status, housekeeping abilities, use of helping aids, received assistance, and sources of personal income. Results indicated no significant differences between the two groups except for the personal income variable of old age pension, which indicated that $31(86.1 \%)$ of the subjects living in senior housing received old age pension but only $11(52.4 \%)$ of those living in their homes in the community did, $\chi^{2}(1)=7.78$ and $p=.005$. Differences between groups were noted for the variables: "Do you use helping aids?", $\chi^{2}(1)=3.38$, $\mathrm{p}=.069$, confirming that $9(31 \%)$ of the senior housing residents used helping aids, whereas only $2(9.5 \%)$ of those living in their own homes out in the community did. Low-income support payments were received by nineteen $(52.8 \%)$ of the subjects in senior housing, while only six $(28.6 \%)$ of the other group received such payments, $\chi^{2}(1)$ $=1.34, \mathrm{p}=.075($ See Table 8$)$. 
Table 8

Significant Differences in Characteristics of the Respondents

\begin{tabular}{|c|c|c|c|c|c|c|}
\hline \multirow[b]{3}{*}{ Variables } & \multicolumn{6}{|c|}{ Living Arrangements } \\
\hline & \multicolumn{2}{|c|}{ Own Home } & \multicolumn{2}{|c|}{ Senior Housing } & \multirow[b]{2}{*}{$\chi^{2}(1)$} & \multirow[b]{2}{*}{ P-Value } \\
\hline & $\mathbf{n}$ & $\%$ & $\mathbf{n}$ & $\%$ & & \\
\hline Receive old age pension & 11 & 52.4 & 31 & 86.1 & 7.78 & $.005^{*}$ \\
\hline Old age income support pension & 6 & 28.6 & 19 & 52.8 & 1.34 & .075 \\
\hline Use helping aids & 2 & 9.5 & 9 & 31.0 & 3.38 & .069 \\
\hline
\end{tabular}

$*=$ Level of significance, $\mathrm{p}=.05$ or less

Table 9 displays scale means $(\underline{M})$, standard deviations and score means $(\mathrm{m})$ of the two groups' beliefs in autonomy and paternalism. Comparison of the data revealed that elderly living in their own homes out in the community hold a slightly stronger belief in autonomy than do those living in senior housing, scoring higher on all autonomy variables except consultant autonomy. Scores of senior housing respondents are slightly higher in consultant autonomy as can be seen by a score mean $(m=4.17$ and $m=4.26$, respectively). 
Table 9

Beliefs Towards Autonomy and Paternalism by Type of Housing

Own Home $\quad$ Senior

Housing

\begin{tabular}{lllllllllll}
\hline Variable & Range & $\mathbf{n}$ & $\underline{M}$ & SD & $\mathbf{m}$ & & $\mathbf{n}$ & $\underline{M}$ & SD & $\mathbf{m}$
\end{tabular}

\begin{tabular}{lrllllllll}
\hline TOTAL AUTONOMY & $30-150$ & 20 & 125.65 & 17.06 & 4.19 & 32 & 116.00 & 17.77 & 3.8 \\
INDEPENDENT A. & $12-60$ & 21 & 45.14 & 8.36 & 3.76 & 36 & 42.39 & 8.47 & 3.5 \\
SHARED AUTONOMY & $18-90$ & 20 & 80.05 & 11.1 & 4.45 & 31 & 72.90 & 11.73 & 4.0 \\
Direct autonomy & $6-30$ & 20 & 20.55 & 4.98 & 3.43 & 34 & 18.18 & 5.36 & 3.0 \\
Consultant autonomy & $6-30$ & 21 & 25.00 & 3.87 & 4.17 & 32 & 25.53 & 4.40 & 4.2 \\
Joint autonomy & $6-30$ & 20 & 25.20 & 5.75 & 4.20 & 34 & 21.82 & 5.33 & 3.6 \\
Delegated autonomy & $6-30$ & 21 & 27.43 & 3.31 & 4.57 & 34 & 25.65 & 3.63 & 4.2 \\
Surrogate autonomy & $6-30$ & 21 & 27.14 & 3.18 & 4.52 & 32 & 25.13 & 4.22 & 4.1
\end{tabular}

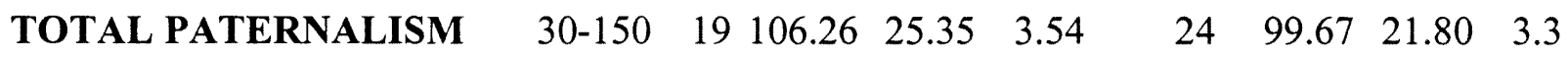

Strong paternalism

$\begin{array}{lllllllll}5-25 & 21 & 18.43 & 5.14 & 3.69 & 31 & 17.55 & 4.89 & 3.5\end{array}$

Indirect paternalism

$\begin{array}{lllllllll}5-25 & 21 & 16.43 & 5.46 & 3.28 & 32 & 13.88 & 5.22 & 2.7\end{array}$

Benevolent paternalism

$\begin{array}{lllllllll}5-25 & 21 & 18.09 & 5.27 & 3.62 & 33 & 16.79 & 4.55 & 3.3\end{array}$

Moderate paternalism

$\begin{array}{lllllllll}5-25 & 20 & 18.25 & 3.88 & 3.65 & 32 & 19.16 & 3.33 & 3.8\end{array}$

Weak paternalism

$\begin{array}{lllllllll}5-25 & 20 & 17.95 & 4.58 & 3.59 & 32 & 16.50 & 4.58 & 3.3\end{array}$

Default paternalism

$\begin{array}{lllllllll}5-25 & 21 & 19.14 & 4.70 & 3.83 & 33 & 18.94 & 4.19 & 3.7\end{array}$

Note. Scores correspond to a Likert scale with: $1=$ strongly disagree,

$2=$ slightly disagree, $3=$ undecided, $4=$ slightly agree and $5=$ strongly agree.

$\underline{\mathrm{M}}=$ Scale mean based on total 
Interestingly, subjects living in their own homes also scored slightly higher than did senior housing respondents on all paternalism subtypes than did the senior housing respondents, except for the moderate paternalism subtype, which may suggest that although rather undecided, the subjects living in senior housing held slightly stronger paternalistic beliefs than did respondents living in their own homes (score mean $\mathrm{m}=3.83$ and $m=3.65$ respectively). Moderate paternalism is when a person in authority intervenes only when there is mental deterioration of the other individual.

In comparing the two groups' beliefs in autonomy and paternalism in different caregiving situations and competence levels of elders, the findings were similar (Table 10). Both groups hold strong beliefs in autonomy in caregiving and competence, with stronger acceptance by elderly living in their own home, as indicated by score means (m) above 4.0 on all types. The Icelandic respondents' beliefs in paternalism in caregiving situations and competence were more neutral although slightly in the direction of agreement with paternalism. Again the community living respondents indicated higher scores in all paternalism situations, with the highest score mean $(\mathrm{m}=3.76)$ in the "confused mind" competence. 
Table 10

Caregiving and Beliefs Toward Autonomy and Paternalism of Elderly by Type of Housing

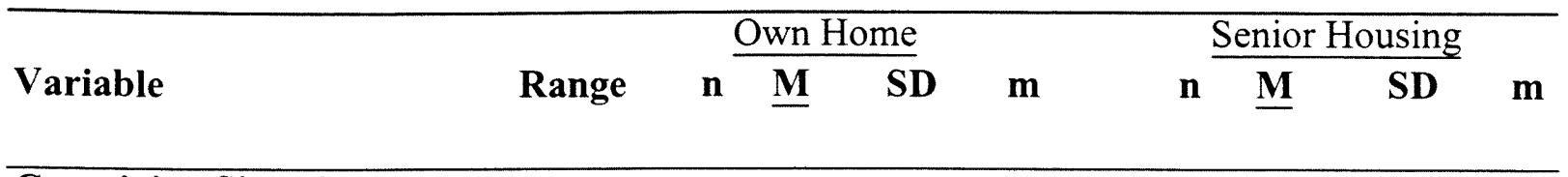

\section{Caregiving Situations}

in Autonomy

Health

$$
\begin{array}{lllllllll}
10-50 & 19 & 42.74 & 5.70 & 4.27 & 28 & 38.86 & 6.90 & 3.8
\end{array}
$$

Financial

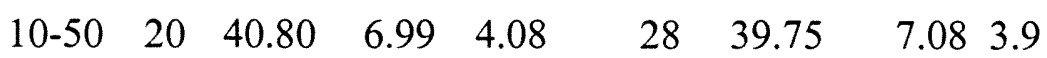

Daily living

$10-50 \quad 19 \quad 43.11$

$6.15 \quad 4.31$

$26 \quad 38.84$

6.943 .8

Elderly Parent Competence in Autonomy

Sound mind

$\begin{array}{rrrrrrrrr}18-90 & 20 & 75.80 & 11.42 & 4.21 & 32 & 70.38 & 12.49 & 3.9 \\ 12-60 & 20 & 49.85 & 7.08 & 4.15 & 34 & 45.38 & 6.62 & 3.7\end{array}$

Confused mind

\section{Caregiving Situations}

in Paternalism

Health

$\begin{array}{lllllllll}10-50 & 21 & 36.14 & 7.89 & 3.61 & 35 & 34.63 & 6.97 & 3.4\end{array}$

Financial

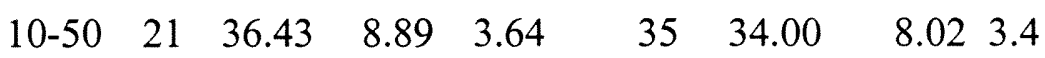

Daily living

$\begin{array}{lllllll}10-50 & 21 & 35.76 & 9.34 & 3.58 & 35 & 33.20\end{array}$

8.133 .3

\section{Elderly Parent Competence in Paternalism}

Sound mind

$\begin{array}{lllllllll}26-130 & 21 & 93.29 & 22.02 & 3.59 & 34 & 88.59 & 18.45 & 3.4\end{array}$

Confused mind

$\begin{array}{lllllllll}4-20 & 21 & 15.05 & 3.47 & 3.76 & 36 & 13.67 & 3.78 & 3.4\end{array}$

Note. Scores correspond to a Likert scale with $1=$ strongly disagree, $2=$ slightly disagree,

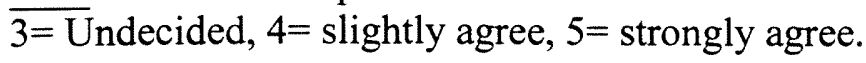

$\underline{M}=$ Scale mean based on total.

$\mathrm{m}=$ Score mean from $1-5$ 
Differences in Beliefs Toward Autonomy and Paternalism

T-tests were performed to determine if there were any significant differences between respondents living in their own homes and respondents living in senior housing complexes on all factors and subtypes of autonomy and paternalism.

Autonomy Scale. In comparing the scale mean scores, there was a marginally significant difference for total autonomy by type of housing, $\mathrm{p}=.059$ (see Table 11). Those living in their own homes more strongly agreed with total autonomy $(\underline{M}=125.65)$ than did those living in senior housing $(\underline{M}=116.00)$. There was a significant difference in shared autonomy where the home living group indicated stronger beliefs in autonomy than did the senior housing respondents $(p=.035)$. The three subtypes of the factor shared autonomy are joint, delegated and surrogate autonomy. The test for joint autonomy indicated that the home living elderly agreed more strongly with respect for autonomy in these types of decision making than did the senior housing elderly, $\mathrm{p}=.034$. The tests for delegated and surrogate autonomy showed marginal significance by type of housing.

Home living elderly also had higher scores for all items in caregiving situations and competence. Significant differences were found in health caregiving situations $(p=.049)$, in daily living $(p=.039)$, and in "confused mind" situations $(p=.024)$. Thus, elderly living in their own homes generally held more autonomous beliefs than did the elderly living in senior housing complexes. 
Table 11

Differences in Beliefs Toward Autonomy of Elderly by Type of Housing

\begin{tabular}{|c|c|c|c|c|c|c|c|c|}
\hline \multirow[b]{2}{*}{ Variable } & \multicolumn{3}{|c|}{ Own Home } & \multicolumn{2}{|c|}{ Senior Housing } & \multirow[b]{2}{*}{ SD } & \multirow[b]{2}{*}{ t-Value } & \multirow[b]{2}{*}{ p-Value } \\
\hline & $\mathbf{n}$ & $\underline{\mathbf{M}}$ & SD & $\mathbf{n}$ & $\underline{\mathbf{M}}$ & & & \\
\hline TOTAL AUTONOMY & 20 & 125.65 & 17.06 & 32 & 116.00 & 17.77 & 1.93 & .05 \\
\hline Independent autonomy & 21 & 45.14 & 8.36 & 36 & 42.39 & 8.47 & 1.19 & .23 \\
\hline Shared autonomy & 20 & 80.05 & 11.10 & 31 & 72.90 & 11.73 & 2.18 & .035 \\
\hline Direct autonomy & 20 & 20.55 & 4.98 & 34 & 18.18 & 5.36 & 1.61 & .11 \\
\hline Consultant autonomy & 21 & 25.00 & 3.87 & 32 & 25.53 & 4.40 & -.45 & .65 \\
\hline Joint autonomy & 20 & 25.20 & 5.75 & 34 & 21.82 & 5.33 & 2.18 & .034 \\
\hline Delegated autonomy & 21 & 27.43 & 3.31 & 34 & 25.65 & 3.63 & 1.83 & .07 \\
\hline Surrogate autonomy & 21 & 27.14 & 3.18 & 32 & 25.13 & 4.22 & 1.87 & .06 \\
\hline
\end{tabular}

CAREGIVING SITUATIONS

Health

$\begin{array}{llllllll}19 & 42.74 & 5.70 & 28 & 38.86 & 6.90 & 2.02 & .049\end{array}$

Financial

$\begin{array}{llllllll}20 & 40.80 & 6.99 & 28 & 39.75 & 7.08 & .51 & .61\end{array}$

Daily living

$\begin{array}{llllllll}19 & 43.10 & 6.15 & 26 & 38.85 & 6.94 & 2.13 & .039\end{array}$

\section{ELDERLY PARENT COMPETENCE}

Sound mind

Confused mind
$20 \quad 75.80 \quad 11.42$

$\begin{array}{lll}20 & 49.85 & 7.08\end{array}$ $\begin{array}{lll}32 & 70.38 & 12.49\end{array}$

1.57

.12

$\begin{array}{lll}34 & 45.38 & 6.62\end{array}$

2.33

Note. Scores correspond to a Likert scale with $1=$ strongly disagree, $2=$ slightly disagree, 3 = Undecided, $4=$ slightly agree, $5=$ strongly agree.

$\underline{M}=$ Scale mean based on total.

$\mathrm{m}=$ Score mean from $1-5$

$*=$ Level of significance $p=.05$ or less 
Table 12

Differences in Beliefs Toward Paternalism of Elderly by Type of Housing

\begin{tabular}{|c|c|c|c|c|c|c|c|c|}
\hline \multirow[b]{2}{*}{ Variable } & \multicolumn{3}{|c|}{ Own Home } & \multicolumn{3}{|c|}{$\underline{\text { Senior Housing }}$} & \multirow[b]{2}{*}{ t-Value } & \multirow[b]{2}{*}{ p-Value } \\
\hline & $\mathbf{n}$ & $\underline{\mathbf{M}}$ & SD & $\mathbf{n}$ & $\underline{\mathbf{M}}$ & SD & & \\
\hline TOTAL PATERNALISM & 19 & 106.26 & 25.35 & 24 & 99.67 & 21.80 & .92 & .36 \\
\hline Strong paternalism & 21 & 18.43 & 5.14 & 31 & 17.55 & 4.89 & .62 & .53 \\
\hline Indirect paternalism & 21 & 16.43 & 5.46 & 32 & 13.88 & 5.22 & 1.71 & .09 \\
\hline Benevolent paternalism & 21 & 18.09 & 5.27 & 33 & 16.79 & 4.55 & .97 & .33 \\
\hline Moderate paternalism & 20 & 18.25 & 3.88 & 32 & 19.16 & 3.33 & -.90 & .37 \\
\hline Weak paternalism & 20 & 17.95 & 4.58 & 32 & 16.50 & 4.58 & 1.11 & .27 \\
\hline Default paternalism & 21 & 19.14 & 4.70 & 33 & 18.94 & 4.19 & .17 & .86 \\
\hline
\end{tabular}

\section{CAREGIVING SITUATIONS}

$\begin{array}{lcccccccc}\text { Health } & 21 & 36.14 & 7.89 & 35 & 34.63 & 6.97 & .75 & .45 \\ \text { Financial } & 21 & 36.43 & 8.89 & 35 & 34.00 & 8.02 & 1.05 & .29 \\ \text { Daily living } & 21 & 35.76 & 9.34 & 35 & 33.20 & 8.13 & 1.08 & .28\end{array}$

\section{ELDERLY PARENT COMPETENCE}

Sound mind

Confused mind

$$
\begin{array}{lll}
21 & 93.29 & 22.02
\end{array}
$$

$\begin{array}{lll}21 & 15.05 & 3.47\end{array}$

$\begin{array}{lll}34 & 88.59 & 18.45\end{array}$

.85

.39

$\begin{array}{ll}36 & 13.67\end{array}$

Note. $\quad *=$ Level of Significance $\mathrm{p}=.05$ or less

Scores correspond to a Likert scale with $1=$ strongly disagree, $2=$ slightly disagree, 3 = Undecided, $4=$ slightly agree, $5=$ strongly agree.

$\underline{M}=$ Scale mean based on total. 
Paternalism Scale. There were no significant differences between groups on any of the paternalism subtypes, in the competence, or in caregiving situations (See Table 12).

\section{$\underline{\text { Additional Findings }}$}

Effects of gender on the beliefs of the respondents. T-tests were performed to determine if there were differences on all factors and subtype variables of autonomy and paternalism between male and female respondents to the survey. Although female scores were generally higher on all autonomy variables except for direct autonomy, only one variable, the surrogate autonomy, was significant $(p=.050)$. This indicated that the female participants would accept decision making by another person in cases where the elderly were incapacitated. The variable, consultant autonomy, was marginally significant $(p=.062)$, suggesting that the elderly women were inclined to accept advice from others before making decisions.

Although the male respondents generally indicated a stronger agreement on the paternalism variables no significant differences were established. However, two variables were marginally significant: Indirect paternalism $(\mathrm{p}=.059)$ and paternalism with "confused mind" ( $p=.071)$, suggesting that males might be less opposed to the use of deception or subtle manipulation of another person in decision making.

Effects of marital status on the beliefs of the respondents. T-tests were performed to determine significant differences on all factors and subtype variables of autonomy and paternalism between respondents that were married or living in a married like 
relationship and those who were either single or widowed. Results are reported in Table 13. Significant differences were found on various autonomy factors, autonomy subtypes and caregiving situations, indicating that married respondents were more in favor of autonomous decision making than were the single ones. Significant differences were found on three autonomy variables; the total, shared and delegated autonomy, and on two autonomy caregiving situations describing daily living situations $(p=.043)$ and with elders of "confused mind" $(p=.027)$. Autonomy with elders of sound mind was marginally significant $(\mathrm{p}=.051)$ while autonomy in health was in the desired direction (Table 13).

Table 13

Effect of Marital Status on the Beliefs of the Respondents

\begin{tabular}{|c|c|c|c|c|c|c|c|c|}
\hline \multirow[b]{2}{*}{ Variable } & \multicolumn{3}{|c|}{ Single } & \multicolumn{3}{|c|}{ Married } & \multirow[b]{2}{*}{ t-Value } & \multirow[b]{2}{*}{ p-Value } \\
\hline & $\mathbf{n}$ & $\underline{\mathbf{M}}$ & SD & $\mathbf{n}$ & $\underline{\mathbf{M}}$ & SD & & \\
\hline Total Autonomy & 30 & 115.13 & 19.24 & 22 & $\overline{125.95}$ & 14.23 & -2.23 & $.030^{*}$ \\
\hline Shared autonomy & 29 & 72.45 & 13.10 & 22 & 80.00 & 8.65 & -2.34 & $.023 *$ \\
\hline Deleg. Autonomy & 31 & 25.13 & 3.96 & 24 & 27.88 & 2.29 & -3.02 & $.004 *$ \\
\hline Aut. in Health & 25 & 38.76 & 7.37 & 22 & 42.32 & 5.30 & -1.88 & .067 \\
\hline Aut. in Daily living & 25 & 38.80 & 7.89 & 20 & 42.95 & 4.59 & -2.08 & $.043 *$ \\
\hline Aut. In Sound mind & 30 & 69.63 & 13.00 & 22 & 76.32 & 10.26 & -2.00 & .051 \\
\hline Aut. In Confused m. & 31 & 45.23 & 7.41 & 23 & 49.48 & 5.90 & -2.27 & $.027 *$ \\
\hline Total Paternalism & 21 & 94.19 & 25.03 & 22 & 110.59 & 18.94 & -2.43 & $.020 *$ \\
\hline Indirect Paternalism & 30 & 13.67 & 5.23 & 23 & 16.48 & 4.93 & -1.92 & .060 \\
\hline Pat. In Daily living & 32 & 32.28 & 9.04 & 24 & 36.67 & 7.46 & -1.93 & .059 \\
\hline
\end{tabular}

Note.

* Level of significance $\mathrm{p}=.05$ or less 
Interestingly, married respondents were also in more agreement with paternalistic beliefs than were the singles group. However, only the total paternalism variable proved significant $(p=.020)$ and two variables, the indirect paternalism and paternalism in daily living were marginally significant.

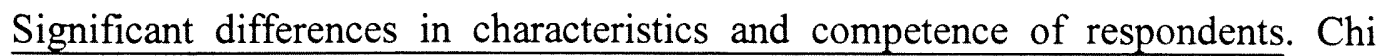
square computations were run on different variables by gender, marital status and emotional health, in order to explore if there were differences in characteristics of the total group of respondents. Results are displayed in Table 14.

Table 14

Differences in Characteristics of Subjects

\begin{tabular}{|c|c|c|c|c|c|c|}
\hline \multirow[b]{3}{*}{ Variables } & \multicolumn{4}{|c|}{ Gender } & \multirow[b]{3}{*}{$\chi^{2}(1)$} & \multirow[b]{3}{*}{ p-Value } \\
\hline & \multicolumn{2}{|c|}{ Male } & \multicolumn{2}{|c|}{ Female } & & \\
\hline & $\mathbf{n}$ & $\%$ & $\mathbf{n}$ & $\%$ & & \\
\hline $\begin{array}{l}\text { Receive assistance } \\
\text { with housekeeping }\end{array}$ & 11 & 61.1 & 8 & 22.2 & 7.96 & $.005 *$ \\
\hline
\end{tabular}
Single $\frac{\text { Marital Status }}{\text { Married }}$

Receive additional low $\begin{array}{llll}15 & 45.5 & 1 & 4.2\end{array}$ $11.73 \quad .001^{*}$ income payment

Emotional Health

Excellent Good to Poor

Receive assistance

$7 \quad 20.6$

12

54.5

6.87

$.009 *$

with houskeeping

$*=$ Level of significance, $p=.05$ or less

$\mathrm{n}=$ number of subjects 
Significant differences were only established for three characteristics. Sixty-one percent (11) of the males but only $22.2 \%$ (8) of the females received assistance with housekeeping, $\chi^{2}(1)=7.96, p=.005$. More singles and widowed elders $(n=15,45.5 \%)$, received additional low income payment, but only one married elder reported receiving such payment, $\chi^{2}(1)=11.73, p=.001$. Seven of those who reported being in excellent health $(20.6 \%)$ needed assistance with housekeeping, while $12(54 \%)$ of the subjects that reported being in good to poor health needed help, $\chi^{2}(1)=6.87, p=.009$.

$\underline{\text { Differences between the Icelandic elderly sample and Cicirelli's elderly parent }}$ sample. In 1989, Cicirelli surveyed 81 elderly parents who had at least one living adult child. There were 17 males and 64 females. Ages of the subjects who patricipated in Cicirelli's study ranged from 66 to 97 , with a mean age of 79.92 years and a standard deviation of 8.51. All subjects were living in a U.S. midwestern city, with a population of about 100,000 . The instruments were administered individually in each subject's home as a part of an interview questionnaire. The means and standard deviations of this current study were compared to score results of Cicirelli's study presented in Table 15 . In comparing the two studies, the Icelandic elderlys' overall scores were higher on the two autonomy factors and the Paternalism scale than Cicirelli's sample of elderly parents, indicating that they held stronger beliefs in autonomy and slightly stronger beliefs in paternalism, than did the U.S. sample. 
Table 15

Differences between Cicirelli's Study and Reykjavik Study

\begin{tabular}{|c|c|c|c|c|c|c|c|c|c|}
\hline \multirow[t]{2}{*}{ Groups } & \multicolumn{3}{|c|}{$\begin{array}{l}\text { Independent } \\
\text { Autonomy }\end{array}$} & \multicolumn{3}{|c|}{$\begin{array}{l}\text { Shared } \\
\text { Autonomy }\end{array}$} & \multicolumn{3}{|c|}{ Paternalism } \\
\hline & $\mathbf{n}$ & $\underline{\mathbf{M}}$ & SD & $\mathbf{n}$ & $\underline{\mathbf{M}}$ & SD & $\mathbf{n}$ & $\underline{\mathbf{M}}$ & SD \\
\hline $\begin{array}{l}\text { Elderly Individuals } \\
\text { from Lafayette, } \mathrm{IN}\end{array}$ & 81 & 36.67 & 3.57 & 81 & 69.98 & 4.19 & 81 & 98.43 & 14.91 \\
\hline $\begin{array}{l}\text { Elderly Individuals } \\
\text { from Reykjavik } \\
\text { area }\end{array}$ & 57 & 43.40 & 8.46 & 57 & 76.71 & 11.91 & 57 & 102.58 & 23.38 \\
\hline $\begin{array}{l}\mathrm{T} \text {-value } \\
\mathrm{P} \text {-value }\end{array}$ & & $\begin{array}{r}-5.30 \\
<.001 *\end{array}$ & & & $\begin{array}{r}-4.09 \\
<.001 *\end{array}$ & & & $\begin{array}{r}-1.18 \\
.240\end{array}$ & \\
\hline
\end{tabular}

Home Living

Elderly

in Lafayette

$\begin{array}{lllllllll}62 & 36.87 & 5.30 & 62 & 69.87 & 5.50 & 62 & 103.68 & 12.96\end{array}$

Home Living

Elderly

in Reykjavik area

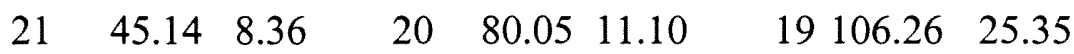

$\begin{array}{lrrr}\text { T-value } & -4.25 & -3.95 & -.43 \\ \text { P-value } & <.001^{*} & <.001^{*} & .668\end{array}$

Elderly in Senior Housing in Lafayette

$15 \quad 35.20$

3.05

$15 \quad 69.13$

1.77

$\begin{array}{lll}15 & 98.93 & 9.03\end{array}$

Elderly in Senior Housing in Reykjavik area 36

36

$42.39 \quad 8.47$

$3172.90 \quad 11.90$

$\begin{array}{lll}24 & 99.67 & 21.80\end{array}$

$$
\begin{aligned}
& \text { T-value } \\
& \text { P-value }
\end{aligned}
$$

$-4.45$

$-1.72$

$-.15$

$<.001^{*}$

.092

.882

Note. $*=$ Level of significance $\mathrm{p}=.05$ or less 
When comparing the mean scores of the two samples in independent autonomy and shared autonomy, the overall scores of the Icelandic sample was 6.73 points higher respectively, and 4.15 points higher on paternalism, again indicating a stronger agreement with paternalistic beliefs than did the Cicirelli sample.

The same trends were seen when comparing groups by housing. The mean scores of Icelandic elderly living in their own home in the community were 8.27 points higher on independent autonomy, 10.18 points higher on shared autonomy and 2.58 points higher on paternalism than were the scores of Cicirelli's sample. When comparing the senior housing groups the Icelandic group again scored higher on all variables, a mean difference of 7.19 points on independent autonomy and 3.77 on shared autonomy. Less difference was found in paternalism, although the Icelandic senior housing respondents scored higher by .74 on the Paternalism scale. However, it has to be pointed out that there was more variety in the responses of the Icelandic sample as can be seen by standard deviations of each variable.

T-tests were run to find out if there were significant differences between beliefs of the participants of the two studies. Significant differences were found on both independent and shared autonomy, indicating stronger autonomous beliefs of the Icelandic sample as a whole sample, and of the Icelandic elderly living in their own homes. The Icelandic elderly living in senior housing also held significantly stronger beliefs in independent differences were found between the senior housing groups on the shared autonomy, factor. There was no difference between any of the groups on Paternalism. 
In answer to research question one, results indicated that the Icelandic elderly living in the greater Reykjavik area held strong beliefs in autonomy. Specific score means revealed more agreement for shared autonomy than for independent autonomy and strong agreement in the subtypes joint, delegate and surrogate autonomy. Results of the Paternalism scale indicated that the Icelandic elderly in general were more undecided in their paternalistic beliefs.

In answer to research question two, differences were found between the two groups of elderly living in senior housing and elderly living in their own homes in the community. The overall RAS score was marginally significant, but significant differences were found on the factor shared autonomy and one of its subfactors joint autonomy, indicating that elderly living in their own homes held stronger belief than did the elderly living in senior housing. The same trend showed in caregiving situations where significant differences were found indicating that the home living elderly held stronger beliefs in caregiving situations concerning health and daily living and with elderly with "confused mind." No significant differences were found in paternalism between the two groups.

Differences were found between the characteristics of the two groups that may expain the differences in the beliefs of the groups. The senior housing elderly in general were older, in poorer health and used more helping aids than did the home living group.

Other interesting findings were noted. Effects of gender differences included women holding higher beliefs than men on surrogate autonomy, and consultant autonomy also was marginally significant. This suggests that women may be more inclined to seek 
advice from others before making decisions, and to accept that others may take over the decision making in case the elderly were incapacitated. In contrast the males held marginally significant stronger beliefs in indirect paternalism $(p=.059)$ and in paternalism in "confused mind" ( $p=.071)$ suggesting that they may be less opposed to use of deception or subtle manipulation by an intervening person. In case of mental incapacitation.

Married elderly were more in favor of autonomous decision making on several variables than were the singles' group. Interestingly married elderly were also more in agreement with paternalistic beliefs than were the single elderly. Differences were found in characteristics of the group. Singles (and widowed) had lower income than the married subjects. The majority of the men reported needing some assistance in housekeeping.

In comparing this current study to Cicirelli's study from 1989, significant differences were found between the two studies, indicating higher beliefs of the Icelandic sample than of Cicirelli's elderly sample. Significant differences were found on variables in autonomy. No significant differences were found between the two studies in paternalism. 


\section{Chapter V}

\section{Discussion}

For people, such as health care professionals and caregivers, who provide assistance to the elderly, it is important to support autonomy of the elders. It is assumed that autonomy and paternalism exist as basic human characteristics, and that beliefs in autonomy affect behavior toward the elderly. Old age is often accompanied by a loss of functional capacity and some opportunities to use remaining abilities, which may result in elderly individuals experiencing a diminished sense of personal control. Loss of functional capacity and the need for assistance may reduce the person's ability to manage his or her own life unimpeded by interference from others and affect the choice of lifestyle and the well-being of the older person. Inappropriate paternalistic acts, on the part of health care professionals or family caregivers can minimize elderly persons' autonomy, giving the elderly a sense of loss of control of their lives. The core of occupational therapy practice is to maximize our clients' independence and autonomy through daily occupations and meaningful activities. It would be difficult to reach those goals if therapists did not believe in and support autonomy of the elderly. Therefore, it is important for occupational therapists to learn more about the perceptions regarding autonomy and paternalism in relation to caregiving of the elderly held by the elderly themselves. 
$\underline{\text { Research Questions }}$

This study was conducted to answer two research questions: (1) What are the attitudes and beliefs of Icelandic elderly individuals toward autonomy and paternalism in caregiving of the elderly? (2) Are there differences in the attitudes and beliefs toward autonomy and paternalism of older persons living in senior housing complexes compared to those living in their own homes in the community?

$\underline{\text { Icelandic Elderly's Attitudes and Beliefs }}$

In answer to the first research question, results indicated that this sample of Icelandic elderly, in general, hold a high respect for autonomy in caregiving situations of their peers. Therefore it is assumed that these elderly subjects would expect their autonomy to be supported in similar situations. Interesting trends were found in the results. In spite of a generally strong support on the autonomy subtypes, the elderly sample seemed to have less of a belief in independent autonomy, the autonomy factor that is considered the most autonomous one, and rather favored the shared autonomy. This indicates that the elderly believe less in situations where elderly individuals make their own decisions totally on their own or preceded by consultation with another person, but would prefer to make joint decisions on these matters with their adult child (joint autonomy), or that they trust the caregiving child to decide either as the elderly person would want, or what the adult child feels best for the parent (delegated autonomy). Also, the elderly showed high respect for surrogate autonomy, which points to their acceptance of decision making by the adult child in the event that the elder is unable to decide for him or herself, provided that the decision is based on what the elderly person would 
choose. Interestingly, the elderly held almost equally high beliefs in autonomy in all health and competence situations, although slightly less when the elderly parent was described as having a "confused mind" than when having a "sound mind".

In general, the Icelandic elderly were slightly undecided in their beliefs toward paternalism, but overall they did not disagree, showing a slight inclination in a positive direction. The elderly agreed least with indirect paternalism, indicating that they were rather undecided if they would accept an intervention by another person that is built on deception or subtle manipulation. They agreed most with default paternalism, which suggests that they would accept the interference of another person to make decisions in case where they would be indifferent to making choices themselves. Default paternalism is one of the statements where Abramson (1985), Árnason (1993), Cicirelli (1989) and Frímannsson (1993) stated that paternalism was more morally acceptable. The elders also were in slight agreement with moderate paternalism, again suggesting that they would accept interference of another individual in decision making, but only to prevent harm. In regards to caregiving situations and elderly parent competence, the trend in paternalism continued. The elderly remained neutral with a slight inclination in the positive direction in all the caregiving situations, showing higher acceptance of paternalistic intervention in situations where the elderly parent was more incapacitated.

There may be several explanations as to why the results show these trends in the elderly responses to the scales. Shared decision making seems to be a preferred way of making choices for this sample of elderly individuals. The reason may be that the majority of the respondents are either married or widowed housewives and through the 
years they have been used to making decisions with another person. Traditional family ties and frequent family contact is still common in the Icelandic culture, with possibilities of reciprocal support and sharing of experiences. According to Cicirelli (1989), shared autonomy has more in common with paternalism than it has with independent autonomy and there seems to be a thin line between sharing decision making with the elderly parent to taking over the decision making in a paternalistic way. It seems to be equally justifiable to this group of elderly to accept paternalistic intervention in all caregiving situations.

In comparison to neighboring countries Iceland is still a young nation. The now aging population have brought their strong cultural values of independence and autonomy into the modern industrialised society of this young sovereign state. Icelandic elderly may not perceive intervention as a threat to their autonomy, but tend to perceive and even expect intervention by relatives as normal support or reciprocal exchanges. Although these trends can be of different intensity they are common within the specific families or particular groups of friends. These strong autonomous beliefs also raise the question about the elders' perceptions of caregiving as a concept and the meaning of the term which may differ from other Nordic countries.

In comparison to other Nordic nations, Icelandic society has little experience in the provision of community services to frail elderly persons. As a result issues about autonomy and paternalism in daily care have not been a contemporary issue. With the greying of the nation and especially the increase in the groups of old-old, occupational therapists need to address what effecst the elders' strong autonomous beliefs may have on 
formal and informal caregiving in the future. As over $70 \%$ of adult carers in this study are working full time plus $12.5 \%$ work part-time in paid employment, in addition to family responsibilities, one can expect changes in informal cargiving. Family caregivers may continue to provide emotional support but physical assistance by family caregivers may have to be supplemented or replaced by services from formal caregivers such as occupational therapists.

Differences in Beliefs Between Two Groups of Community Living Elderly

The second research question asked if there were differences in attitudes and beliefs toward autonomy and paternalism of older persons living in senior housing complexes compared to those living in their homes in the community. In general, the group of elderly living in their homes out in the community held stronger beliefs in autonomy than did subjects living in senior housing complexes, except for consultant autonomy. Both groups were neutral in their belief in individual decision making or direct autonomy, but the senior housing respondents seemed to be more inclined to seek consultation and advice of others before making their decisions, than did the home living group.

Significant differences were found between the two groups in two types of autonomy, the shared autonomy and the joint autonomy, again indicating that the home living elderly held stronger beliefs in consultation and joint decision making than did the senior housing group. The difference between the two groups on total autonomy was marginally significant, and the autonomy subtypes of delegated and surrogate autonomy 
were in the desired direction. These autonomy subtypes may represent a grey area between autonomy and paternalistic beliefs. The trends continued in caregiving situations, where significant differences were found in three of the five caregiving situations, again demonstrating stronger autonomous beliefs of the home living respondents. Surprisingly, the results revealed the highest significance in situations describing the elderly parent with a low competency level. This suggests that the elderly living in their homes in the community would least accept interference in caregiving situations where the elderly are mentally incapacitated. This may create difficulties in the caregiving of mentally incompetent elderly. Elderly without requisite abilities to be autonomous, may continue to live independently without assistance for too long, resulting in serious problems with health, personal safety and financial problems that may not be easily reversed. The reason for this strong support to autonomy in low competency situations may be contributed to the fact that these may be the most frightening situations to be in, and that the elders want to be respected as individuals inspite of not being able to patricipate in decision making as equals. As to caregiving in health situations, one can also speculate how far the elderly would go in accepting physical assistance in the home in case of severe disability. Many elderly have been known to express that if they become too frail they would rather go into a home than to be a burden to the family. A possible explanation may be a perceived imbalance of shared reciprocity, the perception of not being an equal contributor in the relationships. These speculations are issues for future studies.

When comparing the two groups of elders in relation to characteristics or competence between the two groups of elderly, results confirmed that the senior housing 
subjects were older and in poorer physical, emotional and intellectual functioning. These differences between the two groups may explain the slightly stronger autonomous beliefs of the home living group. In general, the home living group are younger, still working elderly that are in better health. It may be that acceptance of some paternalistic practices only occur when people are older and frailer and may accept and trust their adult children to take over and make decisions as they themselves would have done. One can assume that the older generation may look differently on autonomy and caregiving than their adult children. Since the younger generation has many competing roles they may have different expectations than their parents. This would need to be studied.

$\underline{\text { Variables that Affect Autonomous and Paternalistic Beliefs of the Respondents }}$

Effects of gender on the beliefs of the respondents. Differences were found between male and female respondents on autonomy and paternalism. The older women generally held stronger beliefs in autonomy than did the older men. However, differences were found on surrogate autonomy and consultant autonomy was marginally significant, indicating that the older women held stronger beliefs than the older men in decision making by another person in cases of incapacitation of the elderly, and that the women were more inclined to seek advice from another person before decision making than the responding males. In contrast, the male respondents generally indicated stronger beliefs on the paternalism variables. These results may suggest different approaches to be used by caregivers in caregiving and communication with each gender. No significant differences were established. However, the variable indirect paternalism was marginally 
significant, indicating that the males might be inclined to accept deception or subtle manipulative intervention in decision making. Also the variable paternalism in "confused mind" was in the desired direction, suggesting that the males were more inclined to accept paternalistic intervention in cases where the elder was mentally incapacitated. These contrasting trends in autonomy and paternalism may be due to the traditional gender roles of this generation, usually with the male as the sole provider and head of the family and the female as the wife, mother and homemaker relying on the provision of her husband.

Effects of marital status on the beliefs of the respondents. Significant differences were found on various autonomy factors, subtypes and caregiving situations between respondents that were married and of those who were either single or widowed, indicating that married respondents were more in favor of autonomous decision making than were the single respondents. There were significant differences on three autonomy variables, where the married respondents held stronger beliefs in total, shared and delegated autonomy. Also significant differences were seen on three caregiving and competence situations, indicating that married respondents supported autonomous beliefs in daily living, "sound mind" and "confused mind" situations. The variable autonomy in health care situations was in the desired direction. In paternalism only total paternalism was significant, again indicating stronger beliefs of the married respondents.

An explanation of the stronger autonomous beliefs of the married respondents may be that the couples are used to consulting each other before decision making and 
make joint decisions on the issues concerned. Married respondents were younger and in better health than the single and widowed group.

The lack of significant differences between the two groups on paternalism may be attributed to the relatively high number of widows in the singles group. One may suspect that the widows are of a higher age than the married subjects are and possibly in poorer health and economic and occupational status. Differences in beliefs may also be based on the traditional gender role occupied by the formerly married and now widowed females who used to make decisions with their husbands. These husbands may have had a stronger inclination to paternalistic beliefs.

Comparison of the current study to Cicirelli's study. Icelandic elderly held stronger beliefs in elderly autonomy and paternalism than did the elderly parents in Cicirelli's study (1989). The differences may be attributed to differences in sample sizes, a slightly lower mean age of the Icelandic sample or it may be a reflection of strong cultural trends toward autonomy, independence and equality inherited through generations. Another research study of Icelandic elderly beliefs on these issues is needed in order to verify if age related changes exist in the beliefs in paternalism of Icelandic elderly, and to examine if the results support Cicirelli's (1989) prediction that with increased age one would see increase in paternalistic beliefs.

Differences in standard deviations may be due to differences in data gathering techniques. In the Cicirelli study the instruments were applied through individual interviews, whereas with the Icelandic sample the questionnaires where handed out to be answered at group meetings. 
$\underline{\text { Implications }}$

With the aging of the population and the resulting increased health care costs, issues of independence and autonomy will have an increased impact on formal and informal caregiving. Attitudes and beliefs may influence not only the behavior of the elderly, but also the behavior of caregivers. For occupational therapists it becomes increasingly important to understand the perceptions of the elderly on these issues to be better able to support the elders in their roles and habits that are personally meaningful and to to gain control of their environment and of their lives as individuals. It is important for their well-being that they are as autonomous as they choose to be.

It is assumed that therapists and caregivers have a belief in respect for autonomy and paternalism of the elderly, as well as an understanding of the perceptions of the elderly on these issues. A better understanding of the attitudes and beliefs of the elderly toward autonomy in caregiving of their age group gives an indication of how they may be supported. This in turn will assist occupational therapists in their education of family members and in the support of caregivers. At the same time it will support educators in their planning of educational training for occupational therapy students to promote autonomy when working with the elderly.

From this study it was found that generally the Icelandic elderly living in the greater Reykjavik area held strong beliefs in autonomy, favoring shared decision making, with emphasis on joint decisions and seeking advice from others. They were more neutral in their paternalistic beliefs. Elderly living in their homes in the community indicated stronger beliefs on autonomy than did the senior housing group. Elderly women held 
stronger beliefs in autonomy, in contrast to elderly males who were inclined to more paternalistic beliefs. Married subjects were more autonomous than were the single respondents. Elderly living in senior housing complexes were older, frailer and in lower economic and occupational status.

The Icelandic version of the Likert scale may be a limitation to the study. People in the pilot study of the Icelandic versions of both scales had difficulties differentiating between the concepts on the Likert scale. As described in chapter three an experienced statistician provided Icelandic terms, which were said to be comparable to the English Likert scale. These Icelandic terms are used in all Likert type scales in Iceland. Although the terms were meant to be comparable it is possible that due to cultural differences in conceptualization, the translated scale is different from the original English version. This could have affected subjects' scores in this study resulting in either higher or lower scores than subjects using the scales in the United States.

The length of the questionnaire as well as the use of it as a survey questionnaire instead of an interview questionnaire may also be a limitation resulting in exclusions due to incomplete questionnaires. Questions (e.g. about housekeeping abilities and the use of helping aids) will have to be worded more specifically for this age group in future surveys, since the respondents from the supportive senior housing environment with rails, non skid bathroom floors, congregate meals, emergency calls etc. did not perceive themselves as living in an adapted environment or being supplied with helping aids, but evidently perceived these attributes as part of their normal environment. Also it was evident that respondents had difficulties identifying one adult child as caregiver in favor 
of other of their adult children. It may also be a limitation to the study that surveys have not been customary with this generation of Icelanders.

Even though the Icelandic population is small and homogenous, this sample of elderly citizens from greater Reykjavik area is still too small to generalize beyond this sample.

\section{$\underline{\text { Recommendations }}$}

A larger, preferably a random sample from around the country would be more representative and give stronger statistical results. Also interviews would give better results. Much is yet to be explored since little or no research exists on autonomy, paternalism or caregiving issues for that matter. It may be interesting to explore if beliefs in autonomy and paternalism change at certain points in life, for example as roles change following retirement or loss of a spouse, or moving into a nursing home. What are the expectations of the elderly as their health becomes poorer? Are there differences in beliefs of the young old and the old-old? And do adult children look differently on caregiving than do their parents? It may also be interesting to examine respect toward autonomy of the caregivers and the caregivers rights, as well as how do the Icelandic elders and Icelanders in general perceive the concept of caregiving?

The core of occupational therapy practice is to maximize our clients' independence and autonomy through daily occupations and meaningful activities. To be better able to support autonomy occupational therapists need to add knowledge and understanding of these issues to the base of the profession. In order to give better support 
for elderly autonomy it is recommended that education including understanding and discussions of these issues be included in curriculums of occupational therapy and other health care professionals. It is equally important to include knowledge about values and benefits of various types of autonomy and paternalism in the training of formal and informal caregivers, including how to support family caregivers.

\section{$\underline{\text { Summary }}$}

Independence of a person is apt to change throughout a lifespan. As people grow older they may face changes in their physical, psychosocial, cognitive and spiritual functioning. These changes may call for changes in the older person's environment and result in changes of the older person's roles and habits. Most importantly all of these changes may affect the older person's ability to effectively make autonomous decisions.

With the aging population and the increase in health care costs, issues of independence and autonomy will have an increased impact on health care services. Shorter hospital stays and reduction of rehabilitation within institutions call for occupational therapy outpatient and community services. With a specialized knowledge of occupation and independent living occupational therapists can improve life quality of the elderly by understanding their perception of autonomy and paternalism. By adding this knowledge to their professional base, Icelandic occupational therapists will give more relevant information and support to family caregivers, and make a noteworthy contribution to the training of future occupational therapy students. 
A convenience sample of 57 Icelandic elderly were surveyed regarding their attitudes and beliefs toward autonomy and paternalism in caregiving of the elderly and a comparison was made to see if there were differences between the beliefs of older persons living in their own homes in the community and of those living in senior housing complexes. Questionnaires were administered to the sample in order to answer two research questions. What are the attitudes and beliefs of Icelandic elderly individuals toward autonomy and paternalism in caregiving of the elderly? Are there differences in the attitudes and beliefs toward autonomy and paternalism of older persons living in senior housing complexes and of those living in their homes in the community?

In this study the Icelandic elderly from the greater Reykjavik area supported autonomy and held neutral beliefs toward paternalism in general and in all subtypes and caregiving situations. Significant differences were found between the two elderly groups. Elderly living at home indicated stronger beliefs on the autonomy scale compared to those living in senior housing complexes. Elderly women held stronger beliefs in autonomy, while elderly men held stronger paternalistic beliefs than did the women. Married subjects were more autonomous than were the single respondents. Senior housing elders were generally older and in poorer health, and in lower economical and occupational situations.

Much is yet to be explored since little or no research exists in Iceland on autonomy and paternalism or caregiving issues in general. It remains to be seen if trends found in this study will remain or change in the context of the rapid cultural changes occurring particularly in the urban Reykjavík area. It may be interesting to examine if 
beliefs in autonomy and paternalism change at certain points in life. Future research is also needed to determine if the expectations of the elderly change as their health becomes poorer, if there are differences in beliefs between different age groups of elderly and if there are differences in autonomous beliefs between caregiving dyads. Turning from the elder to the caregiver, it is also important to consider the respect for the autonomy of the caregivers and the caregivers'rights also need to be studied.

The cultural concept of caregiving also needs to be defined, especially in context to the shared reciprocity within the Icelandic family. For instance, where does shared reciprocity end and caregiving begin?

Without understanding and knowledge of elderly autonomy it would be difficult for health care professionals to give relevant support to their elderly clients. In order to add to the knowledge base of Icelandic occupational therapy it is recommended that autonomy and paternalism in relation to caregiving of the elderly be included in the academic program and continuing education for Icelandic occupational therapists and occupational therapy students. 


\section{List of References}

Abramson, M. (1985). The Autonomy-Paternalism Dilemma in Social Work Practice.

Social Casework. The Journal of Contemporary Social Work, 66, pp. 387 - 392.

American Occupational Therapy Association (1993). Core Values and Attitudes of

Occupational Therapy Practice. American Journal of Occupational Therapy, 47,

pp. $1086-1087$.

American Occupational Therapy Association (1994). Occupational Therapy Code of

Ethics. American Journal of Occupational Therapy, 48, pp. $1037-1038$.

Árnason, V. (1993). Siðfræði lifs og dauða [Ethics of Life and Death]. Reykjavík: Rannsóknarstofnun í Siðfræði. Háskóli Íslands.

Brown, D. S., Gardner, D. L., Perritt, L. \& Kelly, D. G. (1992). Improvement in Attitudes Toward the Elderly Following Traditional and Geriatric Mock Clinics for Physical Therapy Students, Physical Therapy, 72(4), pp. $251-257$.

Cicirelli, V. C. (1989). Measures of Family Members' Beliefs in Respect for Autonomy and Paternalism in Relation to Care of Elderly Parents: The Respect for Autonomy Scale and the Paternalism Scale. West Lafayette, Indiana: Retirement Research Foundation.

Cicirelli, V. C. (1990). Relationship of Personal-Social Variables to Belief in Paternalism in Parent Caregiving Situations. Psychology and Aging, 5(3), pp. 458 - 466.

Cicirelli, V. C. (1992). Family Caregiving: Autonomous and Paternalistic Decisionmaking. Newsbury Park: Sage Publications. 
Collopy, B. J. (1986). The Conceptually Problematic Status of Autonomy. New York:

Fordham University.

Collopy, B. J. (1988). Autonomy in long term care: Some crucial distinctions. The Gerontologist, 28(Suppl.), pp. $10-17$.

Council of Europe (1996). Iceland. In Recent Demographic Developments in Europe.

Belgium: Council of Europe, Bruxcelles.

Craddock, J. (1996a). Responses of the Occupational Therapy Profession to the Perspective of the Disability Movement, Part 1. British Journal of Occupational Therapy, 59(1), pp. $17-22$.

Craddock, J. (1996b). Responses of the Occupational Therapy Profession to the Perspective of the Disability Movement, Part 2. British Journal of Occupational Therapy, 59(2), pp. $73-78$.

Crowne, D. P., \& Marlowe, D. (1960). A new scale of social desirability independent of psychopathology. Journal of Consulting Psychology, 24, pp. $349-354$.

Félag eldri borgara (1998). Djónustuíbúðir: Hugtak, reynsla, saga [Senior housing: Concept, experience, history]. In Listin að lifa. Félagsrit eldri borgara, 3(1), pp. $14-17$.

Félagsmálastofnun Reykjavíkurborgar (1996). Ársskýrsla 1995. [ Annual Report of the Reykjavík Social Services, 1995]. Reykjavík.

Fillenbaum, G. G. (1980). Comparison of Two brief Tests of Organic Brain Impairement, the MSQ and the Short Portable MSQ. Journal of the American Geriatrics Society, 28(8), pp. $381-384$. 
Frímannsson, G. H. (1993). Hugtakið sjálfræði [The Concept of Autonomy]. In Erindi siðfræðinnar. Reykjavík: Rannsóknarstofnun í Siðfræði. Háskóli Íslands.

Gillon, R. (1985). Autonomy and concent. In M. Lockwood (Ed.), Moral dilemmas in modern medicine. pp 111 - 125. New York: University Press.

Giardina-Rosche, C., Black, M. E. A. (1990). Attitudes of Diploma Student Nurses Toward Adult Clients. Journal of Nursing, 29(5), pp 208 - 214.

Gillis, D. M. (1991). Strategies to Promote Positive Behavior Toward Elderly Patients. Clinical Nurse Specialist, 5(3), pp. $165-168$.

Hagstofa Íslands.(1997). Landshagir [Statistical Yearbook of Iceland]. Reykjavík: Hagstofa Íslands.

Hagstofa Íslands.(1998). Landshagir [Statistical Yearbook of Iceland], unpublished. Reykjavík: Hagstofa Íslands.

Hair, J. F. Jr., Anderson, R. E., Tatham, R. L., \& Black, W. C. (1992). Multivariate Data Analysis with Readings (3rd ed.). New York: Macmillan Publishing Company.

Hasselkus B. R. \& Kiernat, J. M. (1989). Not by Age Alone. Gerontology as a Specialty in Occupational Therapy. American Journal of Occupational Therapy, 43(2), pp. $77-79$.

Heilbrigðis- og tryggingamálaráđuneytið (1997). Lög um málefni aldraðra, [Law on issues concerning the elderly], Reykjavík. Heilbrigðis og tryggingamálaráðu neytið.

Heliken, D., Brophy, E. B., Naughton-Walsh, M., Druyan, M. E., Hungelmann, J. A., Jacobs, M., LaPalio, L., Sabbia-Madden, \& P., Schulte, J. (1993). Research 
Briefs: A Study of Professional Health Care Students'Attitudes Toward Older Adults. Journal of Nursing Education, 32(8), pp. $527-533$.

Himes, C. L. (1994). Parental Caregiving by Adult Women: A Demographic Perspective. Research on Aging, 16(2), pp. $191-211$.

Hummert, M. L., Garstka, T. A., Shaner, J. L., \& Strahm, S. (1995). Judgements About Stereotypes of the Elderly. Research on Aging, 16(2), pp. $168-189$.

Jensen, P. (1995). Ergoterapi i Aalborg: Fra 2 - 50 paa 10 aar. Ergoterapeuten, 56 (13), pp. 4-12.

Kahn, R. L., Goldfarb, A. I., Pollack, M. \& Gerber, I. E. (1960). The Relationship of Mental and Physical Status in Institutionalized Aged Persons. American Journal of Psychiatry, 117(2), pp. $120-124$.

Kielhofner, G. (1985). A Model of Human Occupation. Theory and Application. $1^{\text {st }}$ Edition. Baltimore: Williams and Wilkins.

Kielhofner, G. (1995). A Model of Human Occupation. Theory and Application. $2^{\text {nd }}$ Edition. Baltimore: Williams and Wilkins.

Kielhofner, G. \& Barrett, L. (1998). The Model of Human Occupation. In M. E. Neistadt \& E. Blesdell (Eds.), Willard \& Spackman's Occupational Therapy, $9^{\text {th }}$ Edition. pp. 527 - 529. Philadelphia: J. B. Lippincott Company.

Kiernat, J. M. (1987). Promoting independence and autonomy through environmental approaches. Topics in Geriatric Rehabilitation, 3(1), pp. 1 - 6 .

Kiernat, J. M. (1991). The Rewards and Challenges of Working with Older Adults. In J. M. Kiernat (Ed.). Occupational Therapy and the Older Adult: A Clinical Manual. Ed. Gaithersburg, Maryland: Aspen Publishers, Inc. 
Kolbeinsson, H. \& Jónsson, Á. (1993). Delerium and dementia in acute medical admissions of elderly patients in Iceland. Acta Psychiatrica Scandinavica, 87, pp. $123-127$.

Lagner, S. R. (1995), Finding meaning in caring for elderly relatives: Loss and personal growth. Holistic Nursing Practice, 9(3), pp. $75-84$.

Miller, B. \& Cafasso, L. (1992). Gender Differences in Caregiving: Fact or Artifact? The Gerontologist., 32(4), pp. $498-507$.

Moskowitz, D. S. (1986). Comparison of Self-Reports, Report by Knowledgeable Informants, and Behavioral Observation Data. Journal of Personality, 54(1), pp. $294-317$.

Moskowitz, D. S. (1990). Convergence of Self-Reports and Independent Observers: Dominance and Friendliness. Journal of Personality \& Social Psychology, 58(6), pp. $1096-1106$.

Ólafsson, S. (1985). Hvernig eru Íslendingar? Nokkrar vísbendingar um gildi í menningu Íslendinga. [What are Icelanders like?A few cues about Icelandic cultural values]. Reykjavík: Félagsvísindadeild Háskóla Íslands.

Pálsdóttir, D. (1986). Elderly in Iceland. Rit heilbrigðis og tryggingamálaráðuneytisins, 1. Reykjavík. Heilbrigðis og tryggingamálaráðuneytið.

Seccombe, K.\& Ishii-Kuntz, M. (1991). Perceptions of Problems Associated with Aging: Comparison Among Four Older Age Cohorts. The Gerontologist, 31(4), pp. 527 533.

Sigurgeirsdóttir, S. (1991). Starfsfólk í heimapjónustu. Framtíðarhorfur [The employees of home care services. Prospective thoughts. Tímaritið Félagsmál. 1. 
Sigurgeirsdóttir, S. (1994). Gamalt fólk í Evrópu: Stutt samantekt frá III Evrópuráðstefnu forstöðumanna heimila fyrir aldraða. Haldið í Maastricht í Hollandi, dagana 22. 24. September 1993 [The elderly in Europe: Abstract of Euro-conference for directors of institutions for the elderly]. Fréttabréf félags stjórnenda í Öldrunartbjónustu, 12(1).Reykjavík.

Silverstein, M. \& Litwak, E. (1993). A Task-specific Typhology of Intergenerational Family Structure in Later Life. The Gerontologist, 33(2), pp. 258 - 264.

Skúlason, P. (1995).Forsendur sjálfræðis [The Prerequisites of Independence].In Í skjóli heimspekinnar. Reykjavík: Háskólaútgáfan. Háskóli Íslands.

Smith, G. C., Smith, M. F.\& Toseland, R. W. (1991). Problems Identified by Family Caregivers in Counselling. The Gerontologist, 31(1), pp. $15-22$.

Stephens, M. A. P., Franks, M. M.\& Townsend, A. L. (1994). Stress and Rewards in Women's Multiple Roles: The Case of Women in the Middle. Psychology and Aging, 9(1), pp. $45-52$.

Stephens, M. A. P., \& Franks, 'M. M. (1995). Spillover between Daughters'Roles as Caregiver and Wife: Interface or Enhancement? Journal of Gerontology: Psychological Sciences, 50B(1), pp. 9- 17.

Stone, R. I., Short, P. F.\& Toseland, R. W. (1991). The Competing Demands of Employment and Informal Caregiving to Disabled Elders. Medical Care, 28(6), pp. $513-526$.

Strassbourg Council of Europe (1994). Recent Demographics Development in Europe 1993. Belgium: Council of Europe Press. 
Thomasma, D. C. (1984). Freedom, Dependency, and the Care of the Very Old. Journal of American Geriatric Society, 32, pp. $906-914$.

Wieland G. D. (1994). The Development of Geriatric Services for Elderly Icelanders: Pursuing Equity and Uniformity. In Gill D. and Ingmann S. R. Eds. Eldercare, Distributive Justice and the Welfare State: Expansion or Retrenchment? Albany: Suny Press. pp. $83-110$.

Wieland G. D. \& Pálsdóttir, D.(1986). The Development of Health and Social Services for the Elderly in Iceland: An Overview. Social Sciences Med., 23(12), pp. 1333 1345.

Wolfson, C., Handfield-Jones, R., Glass, K., McClaran, J. \& Keyserlingk, E. (1993). Adult Children's Perceptions of their Responsibility to Provide Care for Dependent Elderly Parents. The Gerontologist, 33(3), pp. 258 - 264.

Young, R. (1986). Personal autonomy: Beyond negative and positive liberty. New York: St. Martin's Press. 
APPENDICES 


\begin{abstract}
APPENDIX A
The Respect for Autonomy and Paternalism Scales

Original Version

Icelandic Version

English Translation of the Icelandic Version
\end{abstract}


Each of the following statements concerns situations of an elderly parent and an adult child. Please tell how much you agree or disagree with each statement.

Please read each statement carefully, then indicate the extent to which you agree or disagree by circling the appropriate letters.

First impressions are usually best. GIVE YOUR OPINION ON EVERY STATEMENT but choose only one answer.

There are no right or wrong answers, only those that are true for you.

If you find that the choices do not adequately reflect your own opinion, use the answer that is closest to the way you feel. Thank you.

\begin{tabular}{|c|c|c|c|c|c|}
\hline & 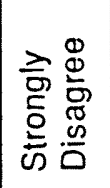 & 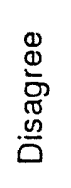 & $\begin{array}{l}\frac{0}{0} \\
\frac{0}{0} \\
\frac{0}{0} \\
\frac{0}{5} \\
\frac{0}{5}\end{array}$ & 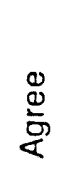 & 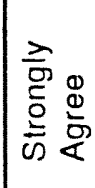 \\
\hline $\begin{array}{l}\text { 1. If an elderly parent of sound mind decides not to } \\
\text { see the doctor about a chronic condition, the adult } \\
\text { child should support the parent's decision. }\end{array}$ & 1 & 2 & 3 & 4 & 5 \\
\hline $\begin{array}{l}\text { 2. If an elderly parent who is emotionally unstable } \\
\text { wants to donate money to charity, the adult child } \\
\text { should help the parent decide how much to give. }\end{array}$ & 1 & 2 & 3 & 4 & 5 \\
\hline $\begin{array}{l}\text { If an elderly parent of sound mind is away and a } \\
\text { broken refrigerator must be replaced, the adult child } \\
\text { should try to decide in the way the parent would. }\end{array}$ & 1 & 2 & 3 & 4 & 5 \\
\hline $\begin{array}{l}\text { 4. If an elderly parent of sound mind must decide } \\
\text { whether or not to have a series of difficult } \\
\text { physiotherapy treatments, the adult child and the } \\
\text { parent should discuss the treatments but the parent } \\
\text { should decide what is to be done. }\end{array}$ & 1 & 2 & 3 & 4 & 5 \\
\hline \begin{tabular}{|l|} 
5. When an elderly parent who is forgetful asks an \\
adult child to make decisions about regular living \\
expenses, the adult child should try to decide things \\
in the way that the parent would.
\end{tabular} & 1 & 2 & 3 & 4 & 5 \\
\hline $\begin{array}{l}\text { 6. If an elderly parent who is of sound mind decides to } \\
\text { drive alone across the country, the adult child } \\
\text { should not interfere. }\end{array}$ & 1 & 2 & 3 & 4 & 5 \\
\hline $\begin{array}{l}\text { 7. When an elderly parent who knows little about } \\
\text { health matters must decide about having a heart } \\
\text { operation, the adult child and the parent should } \\
\text { decide together. }\end{array}$ & 1 & 2 & 3 & 4 & 5 \\
\hline $\begin{array}{l}\text { 8. If an elderly parent is too physically ill to make } \\
\text { decisions about paying household bills, the adults } \\
\text { child should make such decisions but try to decide } \\
\text { as the parent would. }\end{array}$ & 1 & 2 & 3 & 4 & 5 \\
\hline
\end{tabular}




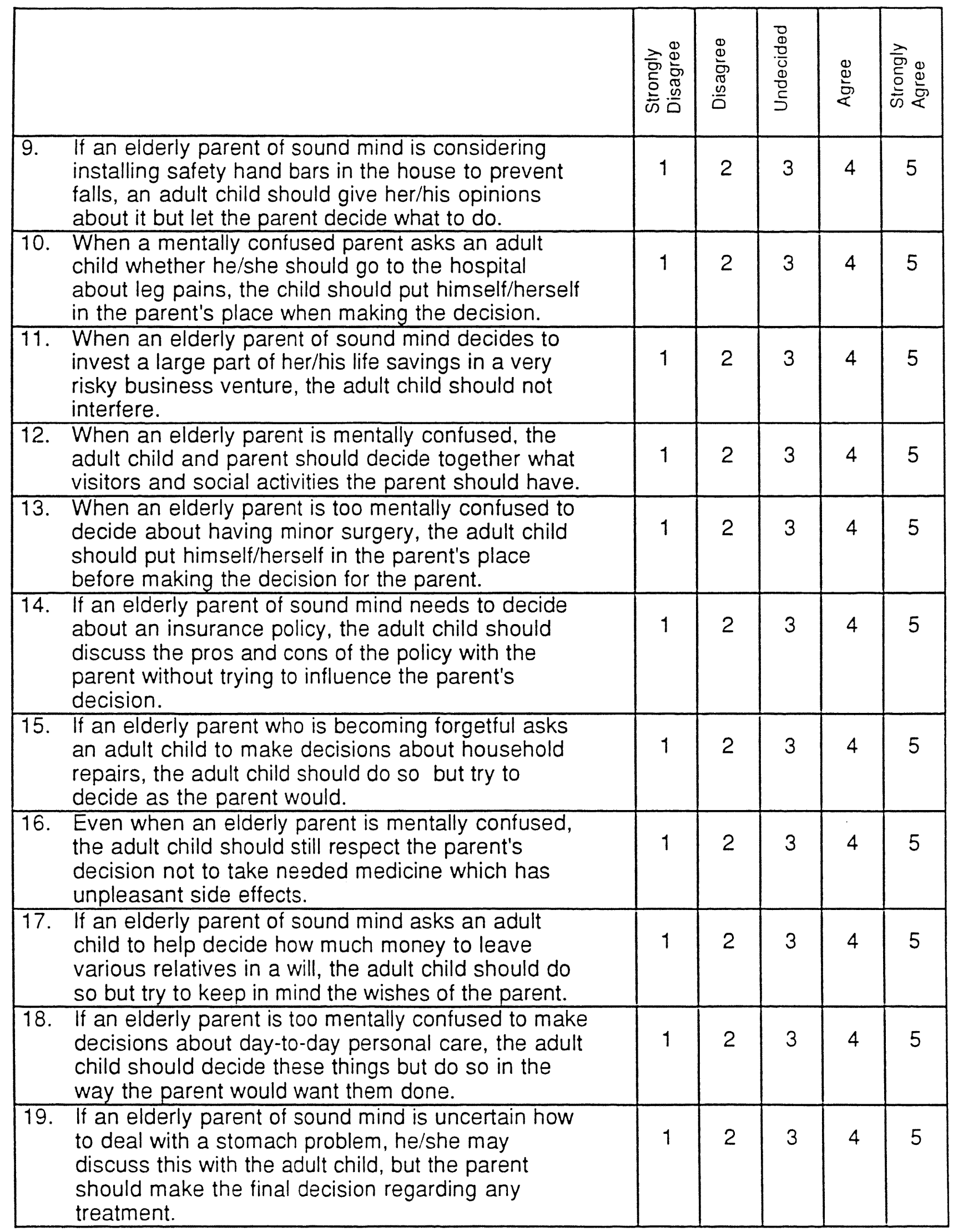




\begin{tabular}{|c|c|c|c|c|c|c|}
\hline & & 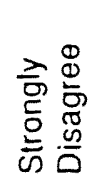 & 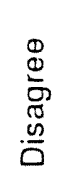 & 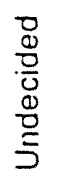 & 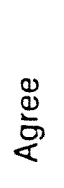 & 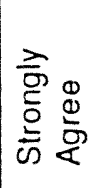 \\
\hline 20. & $\begin{array}{l}\text { If an elderly parent of sound mind asks an adult } \\
\text { child to handle banking decisions the adult child } \\
\text { should do so but make decisions as the parent } \\
\text { would want. }\end{array}$ & 1 & 2 & 3 & 4 & 5 \\
\hline & $\begin{array}{l}\text { When an elderly parent who is very forgetful decides } \\
\text { that he/she would be happier living alone in her/his } \\
\text { own home no matter what the risk to her/his safety, } \\
\text { the adult child should respect that decision. }\end{array}$ & 1 & 2 & 3 & 4 & 5 \\
\hline & $\begin{array}{l}\text { When an elderly parent of sound mind needs to } \\
\text { decide whether or not to go on a weight-reducing } \\
\text { diet, the adult child and parent together should } \\
\text { decide together what to do. }\end{array}$ & 1 & 2 & 3 & 4 & 5 \\
\hline & $\begin{array}{l}\text { If an elderly parent is away on a long trip and cannot } \\
\text { be reached for a needed decision about some } \\
\text { property, the adult child should make the decision as } \\
\text { he/she thinks the parent would have done. }\end{array}$ & 1 & 2 & 3 & 4 & 5 \\
\hline & $\begin{array}{l}\text { If an elderly parent is somewhat mentally confused, } \\
\text { the adult child and parent may discuss the parent's } \\
\text { needs for new clothing, but the parent should } \\
\text { decide what will be bought. }\end{array}$ & 1 & 2 & 3 & 4 & 5 \\
\hline & $\begin{array}{l}\text { If an elderly parent of sound mind asks an adult child } \\
\text { whether or not to see a doctor about headaches, the } \\
\text { adult child should make a decision that fits in with the } \\
\text { parent's views on medical treatment. }\end{array}$ & 1 & 2 & 3 & 4 & 5 \\
\hline & $\begin{array}{l}\text { If an elderly parent who is mentally confused } \\
\text { decides to buy more clothes than he/she needs, the } \\
\text { adult child should not interfere. }\end{array}$ & 1 & 2 & 3 & 4 & 5 \\
\hline & $\begin{array}{l}\text { If an elderly parent of sound mind needs to decide } \\
\text { where to live in later years, the adult child and } \\
\text { elderly parent should reach a decision together that } \\
\text { best fits the parent's needs and values. }\end{array}$ & 1 & 2 & 3 & 4 & 5 \\
\hline & $\begin{array}{l}\text { If an elderly parent of sound mind ignores the need } \\
\text { to make a decision about having medical tests to } \\
\text { find the cause of fainting spells, the adult child } \\
\text { should try to see things from the parent's point of } \\
\text { view to decide whether or not the parent should } \\
\text { take the medical tests. }\end{array}$ & 1 & 2 & 3 & 4 & 5 \\
\hline & $\begin{array}{l}\text { If an elderly parent who can no longer think clearly } \\
\text { needs to budget money for living expenses, the } \\
\text { adult child should discuss the budget with the } \\
\text { parent but the parent should make the actual } \\
\text { decisions about what to spend. }\end{array}$ & 1 & 2 & 3 & 4 & 5 \\
\hline & $\begin{array}{l}\text { When an elderly parent of sound mind asks an } \\
\text { adult child to make decisions about her/his diet, the } \\
\text { adult child should do so, but remember the parent's } \\
\text { likes and dislikes. }\end{array}$ & 1 & 2 & 3 & 4 & 5 \\
\hline
\end{tabular}


Each of the following statements concerns an elderly parent and an adult child. Please tell how much you agree or disagree with each statement.

Please read each statement carefully, then indicate the extent to which you agree or disagree by circling the appropriate letters.

First impressions are usually best. GIVE YOUR OPINION ON EVERY STATEMENT but choose only one answer.

There are no right or wrong answers, only those that are true for you.

If you find that the choices do not adequately reflect your own opinion, use the answer that is closest to the way you feel. Thank you.

\begin{tabular}{|c|c|c|c|c|c|c|}
\hline & & 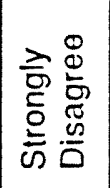 & 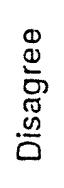 & 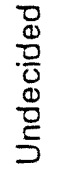 & 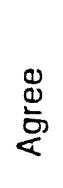 & 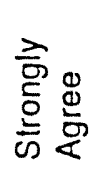 \\
\hline & $\begin{array}{l}\text { No matter how much an elderly parent objects, the } \\
\text { adult child should do whatever he/she thinks is best } \\
\text { for the parent's health in the long run. }\end{array}$ & 1 & 2 & 3 & 4 & 5 \\
\hline 2. & $\begin{array}{l}\text { When an adult child knows more than an elderly } \\
\text { parent about how to manage money, the child } \\
\text { should take charge of the parent's spending, but } \\
\text { explain to the parent why it's necessary to do so. }\end{array}$ & 1 & 2 & 3 & 4 & 5 \\
\hline & $\begin{array}{l}\text { When an elderly parent can no longer take care of } \\
\text { himself/herself, he/she no longer has any say in } \\
\text { how an adult child takes care of him/her. }\end{array}$ & 1 & 2 & 3 & 4 & 5 \\
\hline & $\begin{array}{l}\text { If an adult child decides it is best for an elderly } \\
\text { parent's health, he/she should slip needed } \\
\text { medicine into the parent's food so the parent has no } \\
\text { chance to object. }\end{array}$ & 1 & 2 & 3 & 4 & 5 \\
\hline & $\begin{array}{l}\text { If an elderly parent decides to risk a great deal of } \\
\text { money in a business opportunity that is likely to fail, } \\
\text { the adult child should forbid it. }\end{array}$ & 1 & 2 & 3 & 4 & 5 \\
\hline & $\begin{array}{l}\text { If an elderly parent pays no attention to getting a } \\
\text { proper diet, the adult child should decide what the } \\
\text { parent will eat. }\end{array}$ & 1 & 2 & 3 & 4 & 5 \\
\hline & $\begin{array}{l}\text { When necessary, an adult child should force an } \\
\text { elderly parent to stick to a treatment the doctor } \\
\text { ordered, but also explain the need to do so to the } \\
\text { parent. }\end{array}$ & 1 & 2 & 3 & 4 & 5 \\
\hline & $\begin{array}{l}\text { Regardless of what the parent thinks should be } \\
\text { done, if the parent is too confused to handle money } \\
\text { any more the adult child should decide how to } \\
\text { spend the money for the parent's benefit. }\end{array}$ & 1 & 2 & 3 & 4 & 5 \\
\hline
\end{tabular}




\begin{tabular}{|c|c|c|c|c|c|c|}
\hline & & 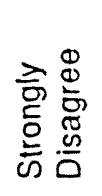 & 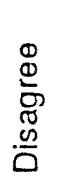 & $\begin{array}{l}\frac{\partial}{d} \\
\frac{0}{0} \\
\frac{0}{0} \\
\frac{D}{D}\end{array}$ & ֻ & 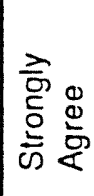 \\
\hline & $\begin{array}{l}\text { If it is for the elderly parent's own good, the adult } \\
\text { child should do whatever is needed for day-to-day } \\
\text { care of the parent regardless of what the parent } \\
\text { thinks should be done. }\end{array}$ & 1 & 2 & 3 & 4 & 5 \\
\hline 10. & $\begin{array}{l}\text { An adult child should let an elderly parent try } \\
\text { whatever treatments the parent thinks best for an } \\
\text { illness, but stop the parent from doing so if the child } \\
\text { thinks the parent would be harmed. }\end{array}$ & 1 & 2 & 3 & 4 & 5 \\
\hline & $\begin{array}{l}\text { When an elderly parent pays no attention to things } \\
\text { like paying bills or paying taxes, the adult child } \\
\text { should take over and manage the parent's money. }\end{array}$ & 1 & 2 & 3 & 4 & 5 \\
\hline & $\begin{array}{l}\text { When an elderly parent has decided to keep an } \\
\text { electrical appliance which the adult child judges to } \\
\text { be unsafe, the child should secretly do something to } \\
\text { keep the appliance from working to be sure the } \\
\text { parent will not use it. }\end{array}$ & 1 & 2 & 3 & 4 & 5 \\
\hline & $\begin{array}{l}\text { When an elderly parent is senile, the adult child } \\
\text { should do what he/she thinks is best for the parent's } \\
\text { health, even if the parent has been against it all } \\
\text { her/his life. }\end{array}$ & 1 & 2 & 3 & 4 & 5 \\
\hline & $\begin{array}{l}\text { It is all right for the adult child to force an elderly } \\
\text { parent to agree to a financial arrangement which is } \\
\text { for the older person's own good, even when the } \\
\text { parent has decided against it. }\end{array}$ & 1 & 2 & 3 & 4 & 5 \\
\hline & $\begin{array}{l}\text { It is all right for an adult child to force an elderly } \\
\text { parent to change her/his daily routine, as long as } \\
\text { the adult child talks to the parent about it and } \\
\text { explains why it is best. }\end{array}$ & 1 & 2 & 3 & 4 & 5 \\
\hline & $\begin{array}{l}\text { When an elderly parent doesn't want to talk or think } \\
\text { about an obvious health problem, the adult child } \\
\text { should insist on taking the parent to the doctor. }\end{array}$ & 1 & 2 & 3 & 4 & 5 \\
\hline & $\begin{array}{l}\text { If an adult child decides that an elderly parent } \\
\text { needs insurance which the parent feels is } \\
\text { unnecessary, the adult child should arrange it } \\
\text { without telling the parent. }\end{array}$ & 1 & 2 & 3 & 4 & 5 \\
\hline & $\begin{array}{l}\text { An adult child should insist on making changes in } \\
\text { an elderly parent's living environment when } \\
\text { something is harmful or unsafe for the elderly } \\
\text { parent. }\end{array}$ & 1 & 2 & 3 & 4 & 5 \\
\hline & $\begin{array}{l}\text { When an elderly parent must decide between } \\
\text { treatments for an illness, the adult child should insist } \\
\text { that the parent choose the treatment that will be best } \\
\text { in the long run. }\end{array}$ & 1 & 2 & 3 & 4 & 5 \\
\hline & $\begin{array}{l}\text { When an elderly parent becomes forgetful about } \\
\text { financial matters. the adult child should take over } \\
\text { and run things as he/she thinks best. }\end{array}$ & 1 & 2 & 3 & 4 & 5 \\
\hline
\end{tabular}




\begin{tabular}{|c|c|c|c|c|c|}
\hline & 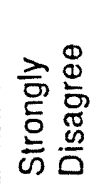 & 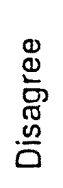 & 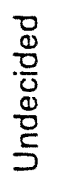 & 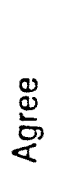 & 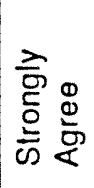 \\
\hline $\begin{array}{l}\text { 21. When an adult child decides that visits from certain } \\
\text { friends are upsetting to the parent, the child should } \\
\text { stop the friends from coming without letting the } \\
\text { parent know. }\end{array}$ & 1 & 2 & 3 & 4 & 5 \\
\hline $\begin{array}{l}\text { 22. When an elderly parent has decided against having } \\
\text { an operation that will prolong her/his life, the adult } \\
\text { child should insist that the parent get the operation. }\end{array}$ & 1 & 2 & 3 & 4 & 5 \\
\hline $\begin{array}{l}\text { 23. When an adult child decides that an elderly parent } \\
\text { should be saving more money for an emergency, } \\
\text { the child should secretly put some of the parent's } \\
\text { money into a savings account each month. }\end{array}$ & 1 & 2 & 3 & 4 & 5 \\
\hline $\begin{array}{l}\text { 24. If an elderly parent is mentally confused, the adult } \\
\text { child should make whatever changes in the parent's } \\
\text { daily routine that he/she judges to be best for the } \\
\text { parent, even when the parent has lived that way for } \\
\text { many years. }\end{array}$ & 1 & 2 & 3 & 4 & 5 \\
\hline $\begin{array}{l}\text { 25. If an adult child can explain why a certain diet is } \\
\text { best for the parent's health, the adult child should } \\
\text { insist that the elderly parent follow the diet. }\end{array}$ & 1 & 2 & 3 & 4 & 5 \\
\hline $\begin{array}{l}\text { 26. When the adult child knows a great deal more } \\
\text { about managing finances than the elderly parent, } \\
\text { the adult child should take charge of the parent's } \\
\text { money matters. }\end{array}$ & 1 & 2 & 3 & 4 & 5 \\
\hline $\begin{array}{l}\text { 27. An adult child should make whatever decisions are } \\
\text { needed about a parent's daily living when the } \\
\text { elderly parent doesn't seem to care what is done. }\end{array}$ & 1 & 2 & 3 & 4 & 5 \\
\hline $\begin{array}{l}\text { 28. If an elderly parent ignores her/his own health, the } \\
\text { adult child should make all decisions about medical } \\
\text { treatments. }\end{array}$ & 1 & 2 & 3 & 4 & 5 \\
\hline $\begin{array}{l}\text { 29. When an elderly parent has decided to spend a lot } \\
\text { of money on an insurance policy that an adult child } \\
\text { regards as worthless, the adult child should prevent } \\
\text { the parent from doing so. }\end{array}$ & 1 & 2 & 3 & 4 & 5 \\
\hline $\begin{array}{l}\text { 30. The adult child should make whatever decisions } \\
\text { about the elderly parent's daily care he/she thinks } \\
\text { will be best for the parent but be sure to tell the } \\
\text { parent why it's best. }\end{array}$ & 1 & 2 & 3 & 4 & 5 \\
\hline
\end{tabular}




\section{Spurningalisti 1}

Sérhver fullyrðing hér á eftir lýsir aðstæðum sem snerta aldrað foreldri og uppkomið barn pess.

Vinsamlega lestu hverja fullyrðingu vandlega og merktu siðan við að hve miklu leyti pú ert sammála eða ósammála með pví að setja hring um viðeigandi tölustaf.

pað sem pér dettur fyrst i hug er yfirleitt besta svarið. LÁTTU ÁLIT PITT Í LJÓs Á HVERRI FULLYR円INGU, en veldu einungis eitt svar við hverri.

Athugaðu að hér eru engin svör rétt eða röng. bú svarar einungis samkvæmt pinni eigin sannfæringu. Ef valkostirnir lýsa ekki skoðunum pínum nægilega, merktu pá við pað svar sem kemst næst pvi sem pér finnst. Kærar pakkir.

1. Ef aldrað foreldri, sem er andlega heilbrigt, ákveður að leita ekki læknis vegna viðvarandi heilsubrests, ber uppkomna barninu að styðja ákvörðun foreldrisins.

2. Vilji aldrað foreldri, sem er i andlegu ójafnvægi, ánafna fé til góðgerðarmála, ætti uppkomna barnið að hjálpa foreldrinu åd ákveđa hve stór upphæðin ætti að vera.

3. Ef aldrað foreldri, sem er andlega heilbrigt, er fjarstatt og endurnÿja parf ónýtan kæliskáp, ætti uppkomna barnið að reyna að taka ákvörðun á sama máta og foreldrið myndi gera.

4. Ef aldrað foreldri, sem er andlega heilbrigt, parf að ákveð̃a hvort pað eigi að fara i erfiðar sjükrapjälfunarmeðferðir, ættu uppkomna bamið og foreldrið að ræða meðferðina en foreldrið ætti að ákveða sjáltt hvað á að gera.

5. Pegar aldrað foreldri, sem er gleymið, biður uppkomið barn að taka ákvörðun varðandi föst útgjöld, ætti uppkomna barnið að reyna að taka ákvörðun á sama hátt og foreldrið hefoi gert.

6. Ákveði aldrað foreldri, sem er andlega heilbrigt, að aka einsamalt út á land langar vegalengdir, ætti uppkomna bamið ekki aj skipta sók af pvi. 


\begin{tabular}{|c|c|c|c|c|c|c|}
\hline & & 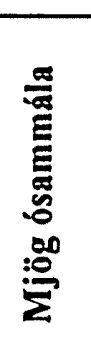 & 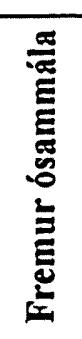 & 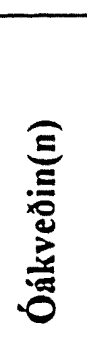 & 㺼 & 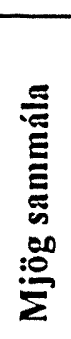 \\
\hline & $\begin{array}{l}\text { Pegar aldrað foreldri, sem hefur litla pekkingu á } \\
\text { málefnum sem snerta heilsufar, parf að ákveða } \\
\text { hvort pað fer i hjartaaðgerð, pá ættu uppkomna } \\
\text { barnið og foreldrið að taka sameiginlega ákvörðun. }\end{array}$ & 1 & 2 & 3 & 4 & 5 \\
\hline 8. & $\begin{array}{l}\text { Ef aldrað foreldri er of likamlega veikt til að taka } \\
\text { ákvarðanir um greiðslu reikninga heimilishaldsins, } \\
\text { ætti uppkomna barnið að taka slikar ákvarðanir en } \\
\text { leitast við að taka ákvörðun eins og foreldrið hefði } \\
\text { gert. }\end{array}$ & 1 & 2 & 3 & 4 & 5 \\
\hline & $\begin{array}{l}\text { Ef aldrað foreldri, sem er andlega heilbrigt, er að } \\
\text { velta pví fyrir sér að setja upp handföng/handrið i } \\
\text { húsinu til að koma i veg fyrir byltur, ætti uppkomið } \\
\text { barn að láta i ljós skoðanir sinar á málefninu en láta } \\
\text { foreldrið ákveða hvað gera skal. }\end{array}$ & 1 & 2 & 3 & 4 & 5 \\
\hline & $\begin{array}{l}\text { Degar aldrað foreldri, sem er farið að slá út i fyrir, } \\
\text { biður uppkomið barn sitt að ákveða hvort pað eigi } \\
\text { að fara á spitala vegna verkja i fótum, ætti upp- } \\
\text { komna bamið að setja sig i spor foreldrisins pegar } \\
\text { pað tekur ákvörðun. }\end{array}$ & 1 & 2 & 3 & 4 & 5 \\
\hline & $\begin{array}{l}\text { pegar aldrað foreldri, sem er andlega heilbrigt, } \\
\text { ákveður að leggja stóran hluta af sparifé sinu i } \\
\text { áhættusöm viðskipti, ætti uppkomna barnið ekki að } \\
\text { skipta sér af pvi. }\end{array}$ & 1 & 2 & 3 & 4 & 5 \\
\hline & $\begin{array}{l}\text { Pegar farið er að slá út i fyrir öldruð̌u foreldri, ættu } \\
\text { uppkomna barnið og foreldrið að ákveða sam- } \\
\text { eiginlega hvaða gestum foreldrið ætti að taka á } \\
\text { móti og hvers konar félagslegum samskiptum pað } \\
\text { ætti að sinna. }\end{array}$ & 1 & 2 & 3 & 4 & 5 \\
\hline & $\begin{array}{l}\text { Pegar farið er að slá svo mikið út i fyrir öldruðu } \\
\text { foreldri, að pað getur ekki tekið ákvörðun um } \\
\text { minniháttar aðgerð, ætti uppkomna barnið að setja } \\
\text { sig i spor foreldrisins áður en tekin er ákvörðun } \\
\text { fyrir foreldrið. }\end{array}$ & 1 & 2 & 3 & 4 & 5 \\
\hline & 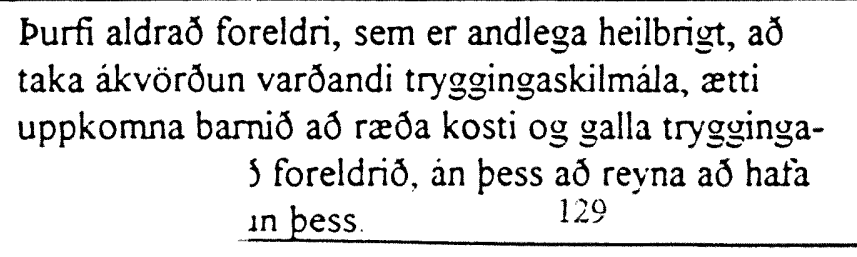 & 1 & 2 & 3 & 4 & 5 \\
\hline
\end{tabular}




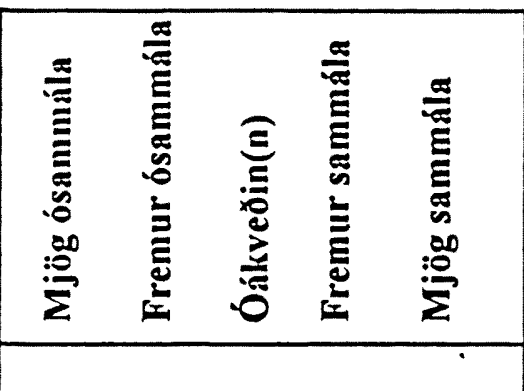

15. Ef aldrað foreldri, sem er að verða gleymið, biður uppkomið barn að taka ákvörðun um viơgerðir á heimilinu, ætti uppkomna barnið að gera pað en $\begin{array}{lllll}1 & 2 & 3 & 4 & 5\end{array}$ reyna að ákveða eins og foreldrið hefði gert.

16. Jafnvel pó farið sé að slá út i fyrir öldruðu foreldri, ætti uppkomið barn samt að virða ákvarðanir foreldrisins um að vilja ekki taka nauơsynleg lyf, sem hafa i för með sér ópægilegar aukaverkanir.

17. Biðji aldrað foreldri, sem er andlega heilbrigt, uppkomið barn sitt um aðstoð við að ákveða hversu mikið fé á að renna til hinna ýmsu ættingja i

$\begin{array}{lllll}1 & 2 & 3 & 4 & 5\end{array}$
erfaskrá, ætti uppkomna barnið að̃ gera pað en reyna að hafa i huga óskir foreldrisins.

18. Sé farið að slá svo mikiơ út í fyrir öldruðu foreldri, að pað geti ekki tekiơ ákvörðun um daglega eigin umhirðu, ætti uppkomna barnið að ákveða pessa hluti eins og foreldrið hefoi viljað.

19. Sé aldrað foreldri, sem er andlega heilbrigt, óöruggt um hvernig bregðast eigi við magaverkjum, gæti pað rætt vandamálið við uppkomna barnið en foreldrið ætti að taka lokaákvörðun um meðferð.

20. Biðji aldrað foreldri, sem er andlega heilbrigt, uppkomið barn sitt að annast bankaviðskipti sin, ætti uppkomna barnio að gera pað en taka ákvarðanir eins og foreldrið myndi vilja.

21. Ef aldrað foreldri, sem er orðið mjög gleymið, ákveður að pað yrði ánægðara með að búa út af fyrir sig, sama hvaða áhrif pað hefoi á öryggi pess, ætti uppkomna barnið að virða pá ákvörðun.

22. pegar aldrað foreldri, sem er andlega heilbrigt, parf að taka ákvörðun um hvort pað eigi að fara á megrunarfæði eða ekki, ættu uppkomna barnið og foreldrið að ákveða i sameiningu hvað à að gera.

$\begin{array}{llllll}1 & 2 & 3 & 4 & 5\end{array}$

$\begin{array}{lllll}1 & 2 & 3 & 4 & 5\end{array}$

$\begin{array}{lllll}1 & 2 & 3 & 4 & 5\end{array}$

$\begin{array}{lllll}1 & 2 & 3 & 4 & 5\end{array}$ 
23. Ef aldrað foreldri er fjarverandi í löngu ferðalagi og ekki er hægt að ná til pess vegna nauðsynlegrar ákvarðanatöku varðandi eignir, ætti uppkomna barnið að taka ákvörðun eins og pað telur að foreldrið hefoi gert.

24. Sé dálítio fario aơ slá út i fyrir öldruðu foreldri gætu uppkomna barnið og foreldrið rætt um pörf pess fyrir nýjan fatnað, en foreldrið ætti að ráða hvað yroi keypt.

25. Spyrii aldrað foreldri, sem er andlega heilbrigt, uppkomið barn sitt um hvort pað ætti að fara til læknis vegna höfuðverkjar, ætti uppkomna barnið að taka ákvörðun i samræmi við skoðanir foreldrisins á læknismeðferð.

26. Ef aldrað foreldri, sem farið er að slá út i fyrir, ákveður að kaupa meiri fatnað en pað hefur pörf fyrir, ætti uppkomna barnið ekki að skipta sér af pví.

27. Durfi aldrað foreldri, sem er andlega heilbrigt, að taka ákvörðun um búsetu á efri árum, ættu uppkomna barnio og foreldriơ að̃ taka sameiginlega ákvörðun sem hæfir best pörfum og gildismati foreldrisins.

28. Ef aldrað foreldri, sem er andlega heilbrigt, hundsar að taka ákvörðun um að fara í læknisrannsóknir til að komast að orsök yfirliðakasta, ætti uppkomna barnið að reyna að skoða málið út frá sjónarhomi foreldrisins til að ákveða hvort foreldrið ætti að fara i læknisrannsóknirnar.

29. Purfi aldrað foreldri, sem er hætt að geta hugsað skýrt, að áætla hversu mikið pað parf til framfærslu, ætti uppkomna barnið að̃ ræða fjárhagsáætlunina við foreldrið en foreldrið ætti að taka ákvörðunina um pá upphæð̃ sem má eyða.

30. Degar aldrao foreldri, sem er andlega heilbrigt, biður uppkomið barn sitt að taka ákvarðanir um mataræ $\mathrm{d}$ pess, ætti barnið ad gera pad en hafa $i$ huga hvaJ foreldrinu pykir gott eða unnt.

$\begin{array}{lllll}1 & 2 & 3 & 4 & 5\end{array}$

$\begin{array}{lllll}1 & 2 & 3 & 4 & 5\end{array}$

$\begin{array}{lllll}1 & 2 & 3 & 4 & 5\end{array}$ 


\section{Spurningalisti 2}

Sérhver fullyrðing hér á eftir lýsir aðstæðum sem snerta aldrað foreldri og uppkomið barn pess.

Vinsamlega lestu hverja fullyrðingu vandlega og merktu sỉðan við að hve miklu leyti pú ert sammála eða ósammála með pví að setja hring um viðeigandi tölustaf.

pað sem pér dettur fyrst í hug er yfirleitt besta svarið. LÁTTU ÁLIT PITT Í LJÓS Á HVERRI FULLYRĐINGU, en veldu einungis eitt svar við hverri.

Athugaðu að hér eru engin svör rétt eða röng. Pú svarar einungis samkvæmt pinni eigin sannfæringu. Ef valkostirnir lýsa ekki skoðunum pínum nægilega, merktu pá við pað svar sem kemst næst pví sem pér finnst. Kærar pakkir.

1. Prátt fyrir eindregin mótmæli aldraðs foreldris ætti uppkomna barnið að gera pað sem pað telur best fyrir heilsu foreldrisins pegar til lengri tíma er litið.

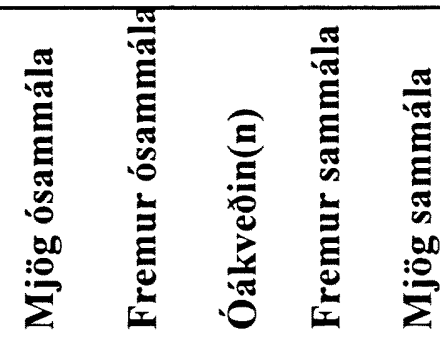

2. Pegar uppkomið barn hefur meiri fjármálapekkingu heldur en aldrað foreldri, ætti barnið að stýra útgjöldum foreldrisins en jafnframt útskýra fyrir pví, hvers vegna pað sé nauðsynlegt.

3. Pegar aldrað foreldri er ekki lengur sjálfbjarga, fær pað ekki lengur neinu ráðið um hvernig uppkomið barn annast pað.

4. Ákveði uppkomið barn að pað sé heilsu aldraðs foreldris fyrir bestu, ætti pað að lauma nauðsynlegum lyfjum í mat foreldrisins svo að foreldrið fá ekki tækifæri til að mótmæla.

5. Ákveði aldrað foreldri að hætta miklu fjármagni í viðskiptum sem eru líkur á að misheppnist, ætti uppkomna barnið að banna pað.

6. Sinni aldrað foreldri pví ekki að borða holla fæðu, ætti uppkomna barnið að ákveða hvað foreldrið eigi að borða.

$\begin{array}{lllll}1 & 2 & 3 & 4 & 5\end{array}$

$\begin{array}{lllll}1 & 2 & 3 & 4 & 5\end{array}$

$\begin{array}{lllll}1 & 2 & 3 & 4 & 5\end{array}$

$\begin{array}{lllll}1 & 2 & 3 & 4 & 5\end{array}$

$\begin{array}{lllll}1 & 2 & 3 & 4 & 5\end{array}$




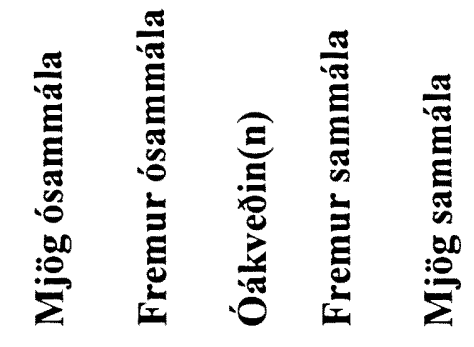

7. Degar nauðsyn ber til, ætti uppkomið barn að neyða aldrað foreldri sitt til að fylgja meðferð sem læknirinn skipar fyrir um, en útskýra um leið fyrir foreldrinu hversvegna nauðsynlegt er að gera pað.

8. Ef svo mikið er farið að slá út í fyrir öldruðu foreldri, að pað geti ekki séð um fjármálin lengur, ætti uppkomna barnið að ákveða hvernig fjármunum foreldrisins er best varið, og skiptir pá engu hvað foreldrinu kann að finnast um pað.

9. Ef pað er aldraða foreldrinu fyrir bestu ætti uppkomna barnið að gera pað sem pörf er á $\begin{array}{lllll}1 & 2 & 3 & 4 & 5\end{array}$ varðandi daglega umsjá pess, án tillits til pess hvað foreldrinu finnst að eigi að gera.

10. Uppkomið barn ætti að láta aldrað foreldri reyna pá meðferð við veikindum sem foreldrið telur að geri mest gagn, en koma í veg fyrir pað telji barnið að foreldrið skaðist af meðferðinni.

11. Sinni aldrað foreldri pví ekki að greiða reikninga eða skatta, ætti uppkomna barnið að taka við og stjórna fjármálum foreldrisins.

12. Ákveði aldrað foreldri að nota áfram raftæki sem uppkomna barnið telur óöruggt, ætti barnið að gera eitthvað á laun til að tækið virkaði ekki og tryggja par með að foreldrið notaði pað ekki.

13. Pegar aldrað foreldri er orðið elliært, ætti uppkomna barnið að grípa til peirra ráðstafana sem pað telur best fyrir heilsu foreldrisins, jafnvel pótt foreldrið hafi verið pví mótfallið alla sína ævi.

14. аð er í lagi að uppkomna barnið pvingi aldrað foreldri sitt til að sampykkja ráðstafanir í fjármálum sem eru hinum aldraða til góðs, jafnvel pótt foreldrið sé pví mótfallið. 
15. аð er í lagi að uppkomið barn neyði aldrað foreldri til að breyta daglegum venjum sínum, svo framarlega sem uppkomna barnið ræði við

$\begin{array}{lllll}1 & 2 & 3 & 4 & 5\end{array}$ foreldrið um pað og útskýri hvers vegna pað sé pví fyrir bestu.

16. Vilji aldrað foreldri ekki ræða eða hugsa um augljóst heilsufarsvandamál, ætti uppkomna barnið

$\begin{array}{lllll}1 & 2 & 3 & 4 & 5\end{array}$ að sækja pað fast að fara með foreldrið til læknis.

17. Ákveði uppkomið barn að aldrað foreldri purfi tryggingu sem foreldrinu finnst vera ópörf, ætti uppkomna barnið að ganga frá málunum án pess að

$\begin{array}{lllll}1 & 2 & 3 & 4 & 5\end{array}$ segja foreldrinu frá pví.

18. Uppkomið barn ætti að krefjast pess að umhverfi aldraðs foreldris verði breytt, sé eitthvað par skaðlegt eða ógni öryggi foreldrisins.

$\begin{array}{lllll}1 & 2 & 3 & 4 & 5\end{array}$

19. Verði aldrað foreldri að velja milli meðferða við sjúkdómi, ætti uppkomna barnið að krefjast pess að foreldrið velji pá meðferð sem mun reynast best pegar til lengri tíma er litið.

20. Pegar fer að bera á gleymsku aldraðs foreldris í sambandi við fjármál, ætti uppkomna barnið að taka við og stjórna peim eins og pað telur best.

21. Pegar uppkomið barn hefur komist að raun um að heimsóknir ákveðinna vina komi foreldrinu í uppnám, ætti barnið að koma í veg fyrir pessar heimsóknir án pess að láta foreldrið vita.

\section{$\begin{array}{lllll}1 & 2 & 3 & 4 & 5\end{array}$}

$\begin{array}{lllll}1 & 2 & 3 & 4 & 5\end{array}$

22. Pegar aldrað foreldri hefur ákveðið að fara ekki í aðgerð sem lengir líf pess, ætti uppkomna barnið að sækja pað fast að foreldrið fari í aðgerðina.

$\begin{array}{lllll}1 & 2 & 3 & 4 & 5\end{array}$

23. Ákveði uppkomið barn að aldrað foreldri ætti að leggja fyrir meira fé til að grípa til í neyð, ætti barnið að leggja hluta af peningum foreldrisins á laun inn á bankareikning mánaðarlega.

$\begin{array}{lllll}1 & 2 & 3 & 4 & 5\end{array}$




\begin{tabular}{|c|c|c|c|c|c|c|}
\hline & $\begin{array}{l}\text { Sé aldrað foreldri illa áttað, ætti uppkomna barnið } \\
\text { að breyta daglegum venjum (dagskipulagi) } \\
\text { foreldrisins eins og pað telur pví fyrir bestu, jafnvel } \\
\text { pótt foreldrið hafi haft pessar sömu venjur í fjölda } \\
\text { ára. }\end{array}$ & 1 & 2 & 3 & 4 & 5 \\
\hline 25. & $\begin{array}{l}\text { Geti uppkomið barn útskýrt af hverju ákveðið } \\
\text { mataræði er hollast fyrir heilsu foreldrisins, ætti } \\
\text { barnið að ganga hart eftir að foreldrið fylgi pví } \\
\text { mataræði. }\end{array}$ & 1 & 2 & 3 & 4 & 5 \\
\hline 26. & $\begin{array}{l}\text { Hafi uppkomna barnið mun meiri pekkingu á } \\
\text { fjármálum heldur en aldraða foreldrið, ætti pað að } \\
\text { taka að sér að annast fjármál foreldrisins. }\end{array}$ & 1 & 2 & 3 & 4 & 5 \\
\hline 27. & $\begin{array}{l}\text { Uppkomið barn ætti að taka allar nauðsynlegar } \\
\text { ákvarðanir varðandi daglegt líf foreldris, pegar } \\
\text { aldraða foreldrinu virðist sama um hvað gert er. }\end{array}$ & 1 & 2 & 3 & 4 & 5 \\
\hline 28. & $\begin{array}{l}\text { Ef aldrað foreldri hugsar illa um heilsu sína, ætti } \\
\text { uppkomna barnið að taka allar ákvarðanir varðandi } \\
\text { læknismeðferð. }\end{array}$ & 1 & 2 & 3 & 4 & 5 \\
\hline 29. & $\begin{array}{l}\text { Degar aldrað foreldri hefur ákveðið að eyða miklu } \\
\text { fé í tryggingu, sem uppkomið barn pess telur } \\
\text { einskis nýta, ætti uppkomna barnið að koma í veg } \\
\text { fyrir pað. }\end{array}$ & 1 & 2 & 3 & 4 & 5 \\
\hline 30 . & $\begin{array}{l}\text { Uppkomna barnið ætti að taka allar ákvarðanir } \\
\text { varðandi daglega umsjá aldraðs foreldis síns, eins } \\
\text { og hann eða hún telja foreldrinu fyrir bestu, en } \\
\text { muna að segja foreldrinu hvers vegna pað er best. }\end{array}$ & 1 & 2 & 3 & 4 & 5 \\
\hline
\end{tabular}




\section{Respect for Autonomy Scale}

Each of the following statements describes the situation concerning an aged parent and a grown up child. Please indicate to what extend you agree or disagree with each statement. The first answer that comes to your mind, is usually the best. Give your opinion on each statement but choose only one answer.

Please have in mind that there are no right or wrong answers. You must answer according to your own belief. If the choices don't describe your opinion sufficiently then mark the next best answer.

Please read every statement carefully and then indicate to what extent you agree or disagree by circling the appropriate number. Thank you.

1. If an aged parent with a clear mind decides not to see a doctor because of chronic illness, it's the grown-up child's duty to support the parent's decision.

2. If an aged parent, who is mentally unstable wants to donate money to charity the grown-up child should help the parent to decide the amount.

3. If an aged parent with a clear mind is absent and the refrigerator needs to be renewed, the grown-up child should try to make a decision in the same way as the parent would do.

4. If an aged parent with a clear mind needs to decide whether to undergo difficult physical therapy treatments the grownup child and the parent should discuss the treatment, but the parent should make the decision.

5. When an aged parent who is forgetful asks a grown-up child to make a decision regarding daily expenses the grown-up child should try to decide the same way as the parent would have decided.

6. If an aged parent with a clear mind decide to drive alone long distances into the countryside the grown-up child should not interfere.

7. When an aged parent whose knowledge of health matters is limited must make a decision concerning having a heart $\begin{array}{lllll}1 & 2 & 3 & 4 & 5\end{array}$ $\begin{array}{lllll}1 & 2 & 3 & 4 & 5\end{array}$ operation, then the grown-up child and the parent should make the decision together.

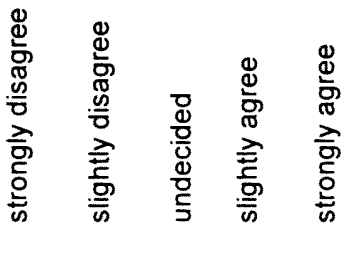

$\begin{array}{lllll}1 & 2 & 3 & 4 & 5\end{array}$

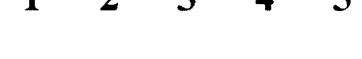

$\begin{array}{lllll}1 & 2 & 3 & 4 & 5\end{array}$

$\begin{array}{lllll}1 & 2 & 3 & 4 & 5\end{array}$

$\begin{array}{lllll}1 & 2 & 3 & 4 & 5\end{array}$

$\begin{array}{lllll}1 & 2 & 3 & 4 & 5\end{array}$ 
8. If an aged parent is too physically ill to make a decision regarding household bills, the grown-up child should make such a decision, but try to do it in the same way as the parent would have done it.

9. If an aged parent with a clear mind is wondering whether to put up safety bars in the house to prevent falls, the grownup child should express it's opinions on the subject but let the parent decide what should be done.

10. When an aged parent who suffers from severe confusion asks his/her grown-up child to decide whether to go to hospital due to pain in the legs should the grown-up child put itself in his/her parents footsteps when it makes the decision.

11. When an aged parent with a clear mind decides to invest a large part of his/her savings in a risky business the grown-up child should not interfere.

12. When an aged parent is too confused the grown-up child and the parent should decide together, which guests should be received and which kind of social activities the parent should have.

13. When an aged parent with so severe mental confusion that it's unable to make a decision about minor operation, the grown-up child should put itself into his/her parents situation before the decision is made for the parent.

14. If an aged parent with a clear mind need to make a decision concerning an insurance policy the adult child must discuss the pros and cons with the parent without trying to influence the parent's decision.

15. If an aged parent who is starting to be forgetful asks the grown-up child to make a decision concerning homemaintenance, the grown-up child should do it, but try to decide the same way as the parent would have done.

16. Even though an aged parent is confused, the grown-up child should still respect the parent's decision about not wanting to take necessary medication, which could cause uncomfortable side effects. 
17. If an aged parent with a clear mind should ask his/her grown-up child for assistance to decide how much money should go to various relatives in a will, the grown-up child should give the assistance, but try to keep in mind the parent's wishes.

18. If an aged parent is so severely confused and cannot make a decision about daily care, the grown-up child should decide those things in the same way as the parent would have done.

19. If an aged parent with a clear mind is uncertain about how to react to stomach problems, he/she could discuss the problem with the grown-up child, but the parent should make the final decision about the treatment.

20. If an aged parent with a clear mind asks the grown-up child to take care of his/her bank-affairs, the grown-up child should do it, but make the same decisions as the parent would have done.

21. When an aged parent, who has become very forgetful, comes to the conclusion that he/she would be happier to live alone in his/her own home, despite the effect it would have on his/her safety, the grown-up child should respect that decision.

22. When an aged parent with a clear mind needs to make a decision about going on a weight reducing diet or not, the grown-up child and the parent should decide together what should be done.

23. If an aged parent is absent on a long vacation and cannot $\begin{array}{lllll}1 & 2 & 3 & 4 & 5\end{array}$ $\begin{array}{lllll}1 & 2 & 3 & 4 & 5\end{array}$ $\begin{array}{lllll}1 & 2 & 3 & 4 & 5\end{array}$ be reached because of necessary decision-making concerning his/her properties, the grown-up child should make the decision in the same way as the parent would have done.

24. If an aged parent is quite confused, the grown-up child and the parent may discuss the need for new clothing, but the parent should decide what would be bought. 
25. If an aged parent with a clear mind asks the grown-up child whether he/she should go to a doctor because of headaches, the grown-up child should make a decision in harmony with his/her parent's view regarding the medical treatment.

26. If an aged parent, who is confused decides to buy more clothing than is needed, the grown-up child should not interfere.

27. If an aged parent with a clear mind needs to make a decision about where to live in his/her old age, the grownup child and the parent should make the decision together in a way that meets the needs and values of the parent.

28. If an aged parent with a clear mind ignores the need to decide to have a medical examination to find out the reason for fainting, the grown-up child should try to view the aspect from the parent's point of view, to decide if the parent should go for a medical check-up.

29. If an aged parent, who is unable to think clearly need to make a budget about daily expenses, the grown-up child should discuss the financial plan with the parent, but the parent should make the decision about the amount, which can be spent.

30. When an aged parent with a clear mind asks his/her grown-up child to make a decision about his/her diet, the grown-up child should do it, but keep in mind what the parent likes or dislikes. 
Each of the following statement regards an aged parent and a grown-up child, Please indicate for each statement to what extend you agree or disagree. The answer that comes first to your mind, is usually the best answer. Give your opinion on every statement, but choose only one answer.

Please note that there are no right or wrong answers. You must answer only according to your belief. If the choices do not describe your opinion sufficiently, then choose the answer that best describes your opinion.

Read every statement carefully and then indicate to what extend you agree or disagree by circling the appropriate number. Thank you.

1. Despite strong protest from an aged parent, the grownup child should do what it believes is best for the parent's health in the long run.

2. When a grown-up child has better financial knowledge than an aged parent, the child should control the parent's

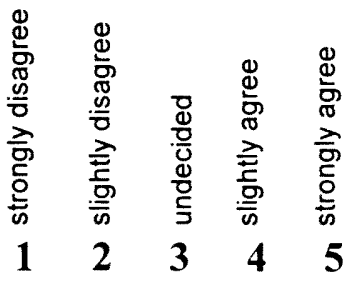
expenses, but simultaneously explain why this is necessary.

3. When an aged parent is no longer able to take care of $\begin{array}{lllll}1 & 2 & 3 & 4 & 5\end{array}$ himself/herself, the parent has no saying in the matter, how the grown-up child takes care of him/her.

4. If a grown-up child decide that it's best for the aged parent's $\begin{array}{lllll}1 & 2 & 3 & 4 & 5\end{array}$ health, then the child should sneak necessary medication into the parent's food, so that the parent doesn't get a chance to refuse.

5. If an aged parent decide to risk a lot of money in a business, which is likely to fail, the grown-up child should forbid it.

6. If an aged parent doesn't think of eating healthy food, the grown-up child should decide what the parent should eat.
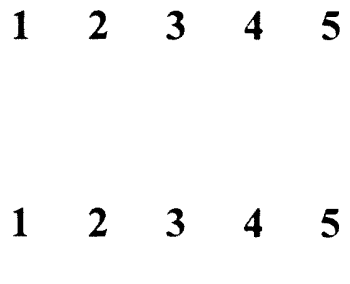
7. When necessary, a grown-up child should force his/her aged parent to follow treatment which the doctor orders, but at the same time explain to the parent why this is necessary.

8. If the parent has become so confused that he/she no longer can take care of his/her finances, the grown-up child should decide how the money should be spent, as he/she thinks best and it doesn't matter what the parent might think.

9. If it's in the parent's best interest that the grown-up child does what is needed to be done regarding his/her daily care, regardless of what the parent believes should be done.

10. A grown-up child should let an aged parent try a treatment to an illness, which the parent thinks will be most useful, but prevent it, if the grown-up child believes the parent can be harmed by the treatment.

11. If the aged parent doesn't pay the bills or taxes, the grownup child should take over and control the parent's finances.

12. When the aged parent decides to continue using an electric appliance which the grown-up child regards unsafe, the child should do something secretly so that the appliance doesn't work and thereby make sure that the parent doesn't use it.

13. When an aged parent has become senile, the grown-up child should take actions he/she believes is necessary and believes is best for the parent's health, even though the parent has disagreed with it all his/her life.

14. It is in order for the grown-up child to force an aged parent to $\begin{array}{lllll}1 & 2 & 3 & 4 & 5\end{array}$ agree on measures regarding finances, which are for the best of the aged parent even though the parent disagrees.

15. It's in order for the grown-up child to force an aged parent to $\begin{array}{lllll}1 & 2 & 3 & 4 & 5\end{array}$ change daily habits, provided the grown-up child discusses this with the parent and explains why this is for his/her own best. 
16. When the aged parent doesn't want to admit or discuss obvious health problem, the grown-up child should demand to take the parent to a doctor.

17. If the grown-up child decides that the parent needs insurance, which the parent thinks is unnecessary, the grown-up child should make arrangements regarding the matter without telling the parent about it.

18. A grown up child should demand that the surroundings of the aged parent to be changed, if there is something that could be harmful or dangerous to the parent.

19. When the aged parent has to choose between treatments for a disease, the grown-up child should demand that the parent chooses the treatment, which works better in the long run.

20. When forgetfulness of the aged parent becomes apparent regarding finances, the grown-up child should take over and control them as he/she believes is best.

21. When a grown-up child has found out that visits from certain friends upsets the parent, the grown-up child should prevent these visits without letting the parent know.

22. When an aged parent has decided not to undergo an operation which prolongs his/her life, the grown-up child should demand that the parent will undergo the operation.

23. When a grown-up child decides that an aged parent should increase the savings for using in an emergency, the child should deposit some of the parent's income secretly into a bank account monthly.

24. If the aged parent is so confused, the grown-up child should change the daily habits (routines) of the parent like he/she thinks is best, even though the parent has had these same habits for many years. 
25. If a grown-up child can explain why certain diet is healthier for the parent's health, then the child should insist that the parent follow the diet.

26. When the grown-up child has considerable more knowledge

$\begin{array}{lllll}1 & 2 & 3 & 4 & 5\end{array}$ in finances than the aged parent, he/she should take charge of the parent's finance.

27. A grown-up child should make all necessary decisions regarding the parents daily life, when the aged parent appears not to care.

28. If an aged parent doesn't take good care of his/her health, the grown-up child should make all the decisions regarding medical treatment.

29. When an aged parent has decided to spend a large amount on insurance, which the grown-up child thinks is worthless, the grown-up child should prevent this.

30. The grown-up child should make all the decisions regarding $\begin{array}{lllll}1 & 2 & 3 & 4 & 5\end{array}$ daily care of the aged parent he/she thinks is best for the parent, but remember to tell the parent why this is for the best. 


\title{
APPENDIX B
}

\author{
Questions to Panel
}

About

Concepts of Autonomy and Paternalism 
1. How would you in your own words define the concept of autonomy?

2. Do you think this concept exits in Iceland?

3. Do you think the concept of autonomy as understood in Iceland is in anyway different from other countries?

4. How would you in your own words define the concept of paternalism?

5. Do you think this concept exits in Iceland?

6. Do you think the concept of paternalism as understood in Iceland is in anyway different from other countries?

7. Can you describe the relationship between autonomy and paternalism if you think there is one?

8. What is your opinion on autonomy and paternalism in care of the elderly? 


\section{APPENDIX C}

Demographics

Original English Version

Icelandic Version

English Translation of the Icelandic Version 


\section{Care of the Elderly}

Thank you for agreeing to complete this questionnaire regarding factors that may influence care of the elderly. As the number of elderly persons in our society increases, it is very important that we look at the issues associated with care of the elderly. Your participation is very important to the study:

You are asked to give your name, only because we will need to contact some people for a follow-up survey at a later date. All responses will remain anonymous and information will only be reported as a group.

\section{It is important that you answer all the questions.}

Throughout the questionnaire "elderly parent" refers to a person who is 60 years or older. To answer each question, either circle the number that corresponds to your chosen response or fill in the blank spaces with the appropriate response.

SAMPLE: Name:

(Last) (First)

Gender: 1. Female 2. Male

1. Identification No.

2. Code No.

3. Name:

(Last)

(First)

4. Address:

(Number) (Street name)

5.

(City) (State) (Zip Code)

6. Telephone:

7. Are you... 1. Female or 2. Male?

8. In what year were you born? 1

That makes you now __ years old.

9. Are you now married, widowed divorced, separated, or were you never married?

1. currently married (spouse living)

2. widowed

3. divorced

4. separated

5. never married

6. living with someone in a marriage-like relationship

10. What is your race?

1. American Indian or Alaskan Native

2. Asian or Pacific Islander

3. African American/Black

4. White

5. Other (write in below) 
11. Are you of Hispanic descent?

1. Yes (answer 11A.)

2. No (skip to question 12)

11A. What is your Spanish/Hispanic origin? If more than one, circle the one you consider the most important part of your background.

1. Mexican, Mexican-American, Chicano

2. Cuban, Cubano

3. Puerto Rican, Puertorriqueno, Bouricuan

4. Other (write in below)

12. Do you speak a language other than English at home?
1. Yes
2. No

13. If yes, indicate the language below.
1. Spanish
2. French
4. Portuguese
3. Creole
5. Chinese
6. Other indicate

14. What is your religious affiliation, if any?
1. Catholic
2. Protestant
3. Jewish
4. Muslim
5. None
6. Other (write in)

15. Where do you now live?
1. In a house or condo I own
2. In a rented house or apartment
3. In the home of a family member
4. Other: Specify

16. How far have you gone in school? (circle only one)
1. elementary school
2. some high school
3. high school diploma
4. vocational school beyond high school
5. some college/university study
6. bachelor's degree
7. graduate study 
17. Are you now working full-time, part-time, attending school, keeping house? Circle only one answer. (If you are a student, circle only number 7 .)

1. working full-time ( 35 hours per week or more)

2. working part-time

3. unemployed, looking for work

4. homemaker (no paid employment outside home)

5. retired - not employed

6. retired - working part-time

7. student

8. Other: Specify

18. Do you have at least one elderly parent living (60 years or older) ?
1. Yes
2. No
If no go to question 28

19. If you do have an elderly parent living, does this person live locally?
1. Yes
2. No

20. Where does your elderly parent live?
1. With me
2. Same city or local area
3. Same state
4. Same country
5. Different country

21. How far away, in terms of travel time, does your elderly parent live?
1. Lives with me
2. In walking distance (few blocks)
3. Thirty minutes or less drive one way
4. More than thirty minutes but less than one hour's drive one way
5. One to three hour drive one way
6. Over three hours drive one way

22. Do you consider yourself to have a caregiving role with your elderly parent?
1. Yes
2. No

23. How do you rate your elderly parent's ability to take care of her/himself from personal care to managing her/his own business affairs?

1. completely independent; she/he can do everything for self

2. mainly independent; but she/he needs assistance with one or two tasks

3. does about half of care by self; needs assistance with the other half of the tasks

4. does a few things for self; needs assistance with most tasks

5. mainly dependent; need assistance of another person to do most things 
If your elderly parent lives locally, would you list her/his name and address so we may ask if she/he would also complete a questionnaire?

24. Name (print):

$$
\text { (Last) (First) }
$$

25. Address:

$$
\text { (Number) (Street name) }
$$

26.
(City)
(State) (Zip Code)

27. Telephone:

If you are a student, answer the following questions. If you are not a student, please go to the next section. Thank you.

28. In what year of college or university are you currently enrolled? (List your present level, even if you previously have had additional years of school.)
1. year one
2. year two
3. year three (junior)
4. year four (senior)
5. year one professional master's
6. year two professional master's
7. year three professional master's
8. advanced master's

29. What is your status in school?

1. Full-time student; not working

2. Full-time student; working part-time

3. Full-time student; working full-time

4. Part-time student; not working

5. Part-time student; working part-time

6. Part-time student; working full-time 


\section{Skimpróf á vitrænni starfsemi.}

Pakka pér fyrir að taka pátt í pessu skimprófi. pátttaka pín er mjög mikilvæg fyrir rannsóknina.Vera má að pú veltir pví fyrir pér hvers vegna pú ert spurð/ur pessara 10 spurninga. pær eru hluti af staðlaðri aðferð sem fara parf eftir áður en farið er að svara spurningalistunum um sjálfræði og forræði. Mikilvægt er að spurningunum sé svarað áður en að spurningalistunum kemur pví öll framkvæmd rannsóknarinnar verður að vera rétt svo hún teljist marktæk.

\section{The Mental Status Questionnaire}

1.) Hvar erum við núna (staðarheiti)

2.) Hvar er pessi staður (staðsetning)?

3.) Hvaða dagur er í dag?

4.) Hvaða mánaðardagur er í dag (dagsetning)?

5.) Hvaða ár er núna?

6.) Hvað ertu gömul/gamall?

7.) Hvenær áttu afmæli?

8.) Hvaða ár fæddist pú?

9.) Hver er forseti Íslands núna?

10.) Hver var forseti næst par á undan? 


\section{Umönnun aldraðra}

Spurningalisti aldraðs foreldris.

Pakka pér fyrir að sampykkja að svara spurningum um atriði sem geta haft áhrif á umönnun aldraðra. par sem fjöldi aldraðra í pjóðfélaginu fer vaxandi, er mjög mikilvægt að velta fyrir sér málefnum er tengjast umönnun aldraðra. pátttaka pín í pessari rannsókn skiptir pví miklu máli. Spurningalistinn er nafnlaus og upplýsingar verða einungis birtar í hópniðurstöðum.

pað er mikilvægt aðö ölum spurningum sé svarað.

En tekið skal fram að pér er ekki skylt að svara einstökum spurningum

eða listanum i heild

Með orðunum "aldrað foreldri” i spurningakönnuninni er átt við einstakling sem er 65 ára eða eldri.

Spurningum er svarað með pví að krossa í viðeigandi reiti, fylla í eyðurnar með viðeigandi svari eða setja hring utan um pann tölustaf sem er í bestu samræmi við skoðun pína. Pað tekur um pað bil 45 mínútur að svara spurningalistunum.

1. Spurningalisti númer:

2. Rannsóknarnúmer:

494

3. Ertu... $\square_{1}$ karl eða $\square_{2}$ kona?

4. Hvað ertu gamall/gömul?

ára.

\section{Hver er hjúskaparstaða pín?}

$\begin{array}{ll}\square_{1} & \text { einhleyp/ur } \\ \square & \text { i óvígðri sambúð } \\ \square & \text { gift/kvæntur } \\ \square_{4} & \text { skilin/n að borði og sæng } \\ \square & \text { fráskilin/n } \\ \square & \text { ekkja/ekkill }\end{array}$

\section{Hverrar trúar ert bú?}
$\square_{1}$ ég er lútherstrúar
$\square_{2}$ ég hef aðra trú en lútherstrú
$\square_{3}$ ég er trúlaus 


\section{Hvernig var skólagöngu pinni háttað?}

(Merktu við siðasta próf eða hoesta skólastig).

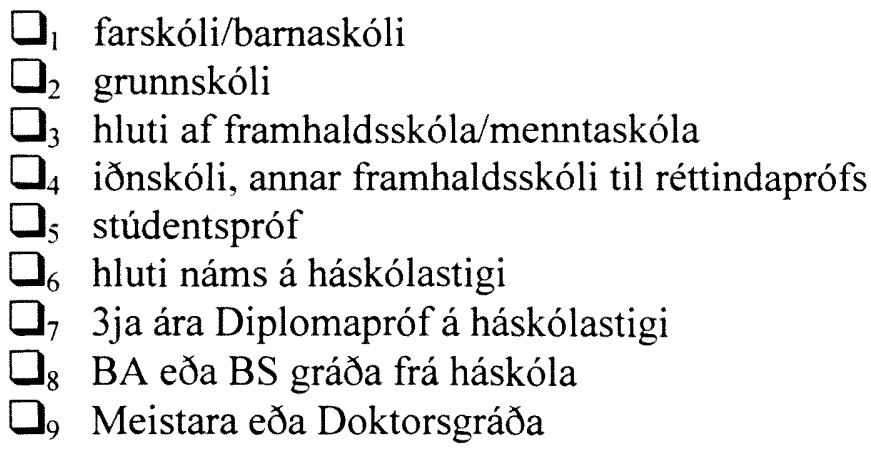

8. Hver af eftirfarandi fullyrðingum segir best til um starf pitt?

(Merktu aðeins við einn reit.)

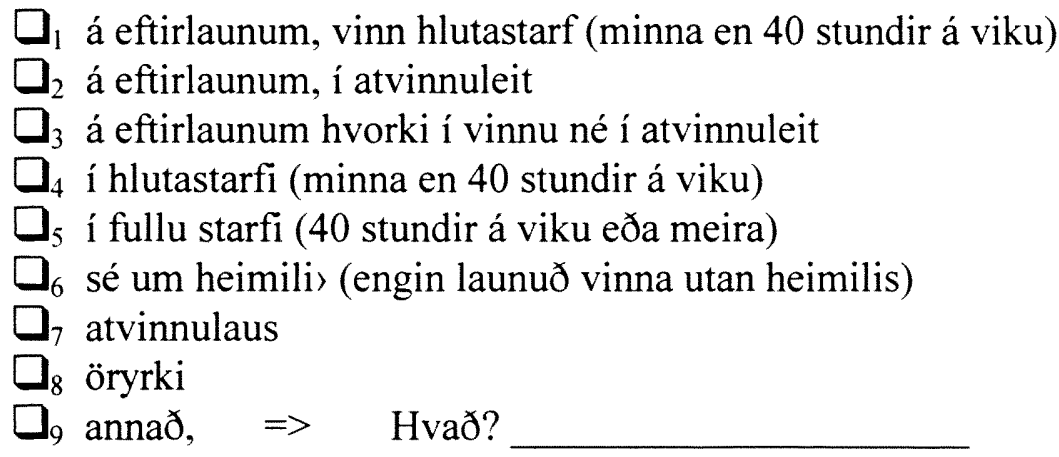

\section{Hvert er pitt aðalstarf?}

Ef pú ert á eftirlaunum eða atvinnulaus, hvaða starf stundaðir pú fyrir starfslok?

(Skýrðu frá pvi hvað starfið kallast, til døemis kokkur, stálsmðður, verslunarmœer, ljósmóðir. Ekki nafnið á vinnustaðnum pinum). 
Hér eru nokkrar spurningar um hagi pína og almenna færni sem talin er nauðsynleg til sjálfstæðrar búsetu. Fjöldi aldraðra í pjóðfélaginu fer vaxandi. pví er mikilvægt að afla upplýsinga um skoðanir pínar á pessum málefnum. Skoðanir pínar eru mikilvægar.

10. Hvernig er heilsufar pitt almennt séð bessa dagana? (T.d. mjög gott = engar likamlegar kvartanir; frekar gott $=$ stundum veik/ur; samilegt $=$ oft veik/ur; slamt = alltaf veik/ur.)
$\square_{1}$ mjög gott
$\square_{2}$ frekar gott
$\square_{3}$ sæmilegt
$\square_{4}$ slæmt

11. En hvernig er andleg líoan pín pessa dagana pegar á heildina er litiơ? (T.d. ertu kviðin/n, öryggislaus, punglynd/ur eða einmana?)
$\square_{1}$ mjög góð
$\square_{2}$ frekar gó
$\square_{3}$ sæmileg
$\square_{4}$ slæm

12. Hvernig myndir bú lýsa hugsanafærni pinni svona yfirleitt? (T.d. gleymirðu fundartímum, áttu erfitt með að taka ákvardanir eða að fylgjast með málum sem eru i almennri umraðu?)
$\square_{1}$ mjög góð
$\square_{2}$ frekar gód
$\square_{3}$ sæmileg
$\square_{4}$ slæm

13. Hvernig gengur með̌ heimilishaldið? Sérð pú um pað hjálparlaust?

$\square_{1}$ já

$\square_{2}$ nei $\quad \Rightarrow \quad$ Við hvað parftu aðstoð?

( Merktu við pau atriði sem pú parft aðstoð við.)

$\square_{1}$ að komast á milli staða innan göngufæris frá heimili

$\square_{2}$ að sjá um aðdrætti og fatakaup

$\square_{3}$ að annast matartilbúning, einkum stærri heitar máltíðir

$\square_{4}$ að sinna erfiðari húsverkum, t.d. skúra, ryksuga og pvo pvotta

$\square_{5}$ að sjá um fjármál, t.d. dagleg innkaup, fara í banka, greiða reikninga

$\square_{6}$ að taka lyfin i réttum skömmtum á réttum tímum 
14. En hvað̃ um eigin umsjá? Séro pú um pig hjálparlaust?

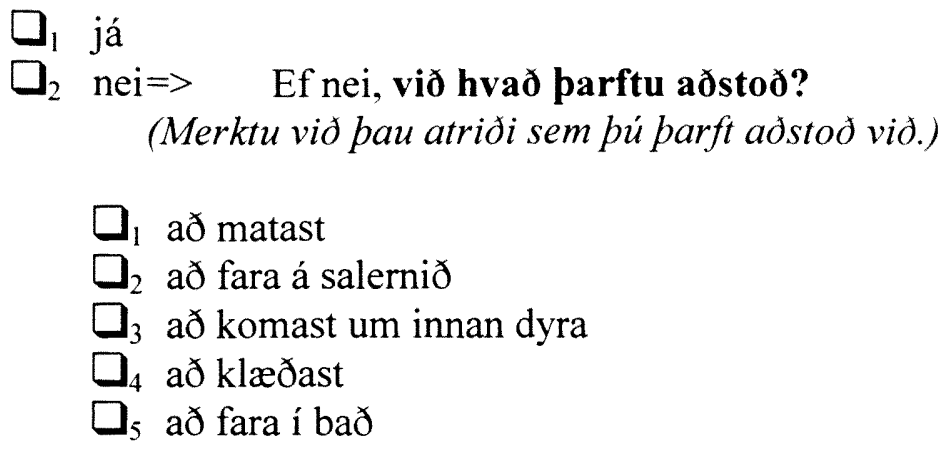

15. Notar pú hjálpartæki til að̃ auðvelda pér að̃ athafna pig?

$\square_{1}$ nei

$\square_{2}$ já $\Rightarrow \quad$ Hvaða tæki notar pú helst?

\section{Hvernig er búsetu pinni háttað?}

$\square_{1}$ bý í eigin húsnæði

$\square_{2}$ bý í leiguhúsnæði

$\square_{3}$ bý hjá barni/ættingjum

$\square_{4}$ bý í pjónustuíbúð/íbúð hönnuð fyrir aldraða

$\square_{5}$ annars staðar; $\quad \Rightarrow$ Hvar?

17. Er núverandi búsetuform sá kostur sem pú kýst helst?
$\square_{1}$ já
$\square_{2}$ nei

18. Býrð bú í pjónustuíbúð eða íbúð sérhannaðri fyrir aldraða?

$$
\begin{aligned}
& \square_{1} \text { nei } \\
& \square_{2} \text { já } \Rightarrow \quad \begin{array}{l}
\text { Ef já, hvers vegna kaust pú petta búsetuform? } \\
\text { (Merktu við allt sem við á) }
\end{array} \\
& \square_{1} \text { ég vildi minnka við mig rekstur á húsnæði } \\
& \square_{2} \text { til að losna við að sjá um viðhald og garðvinnu } \\
& \square_{3} \text { i leit að öryggi eða meiri stuðningi } \\
& \square_{4} \text { til að komast í rólegra umhverfi } \\
& \square_{5} \text { til að komast í félagsskap jafnaldra } \\
& \square_{6} \text { fyrra húsnæði var orðið óhentugt } \\
& \square_{7} \text { annað } \quad \Rightarrow \text { Hvað? }
\end{aligned}
$$


19. Myndir bú kjósa að̉ búa á eigin heimili úti í bæjarfélaginu allt til dauðadags? (Að pvi tilskyldu að öll nauðsynleg pjónusta og stuðningur sé tryggður af hálfu samfélagsin.)
$\square_{1}$ já
$\square_{2}$ nei

20. Á hverju byggist afkoma pín helst ?

(Rððaðu öllum tekjuliðum sem við á i forgangsröð, pœr mikilvœegustu númer

1., naestmikilvogustu nr. 2, og svo koll af kolli.)
$\square_{1}$ lífeyrissjóðum
$\square_{2}$ atvinnutekjum
$\square_{3}$ fjárhagsstuðningi barna
$\square_{4}$ tekjutryggingu
$\square_{5}$ ellilífeyri
$\square_{6}$ heimilisuppbót
$\square_{7}$ örorkubótum
$\square_{8}$ öðru $\quad \Rightarrow$ Hverju?

\section{Hvernig gengur pér að komast af fjárhagslega?}

T.d. finnst pér pú hafa nægilegt fé milli handa til að eyða i "smá munað” eða "gleðigjafa" eins og leikhúsmiða, gjafir, kaffihús, eða hársnyrtingu?

$\square_{1}$ Ég hef alltaf ráð á að eyða í "smá munað”"

$\square_{2}$ Ég hef oftast ráð á að eyða í "smá munað"

$\square_{3}$ Ég hef stundum ráð á að eyða i "smá munað"

$\square_{4}$ Ég hef sjaldan ráð á að eyða í "smá munað"

$\square_{5}$ Ég hef aldrei ráð á að eyða í "smá munað” 
Eftirfarandi spurningar eru um pað barn pitt uppkomið sem pú treystir mest á með aðstoð við pig (eða myndir treysta mest á i framtiððinni).

22. Hvort er pað barn pitt sonur eða dóttir?

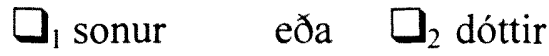

23 Hversu gamall/gömul er hann/hún ?

ára

24. Hver er hjúskaparstétt barns píns?

$\square_{1}$ einhleyp/ur
$\square_{2}$ í óvígðri sambús
$\square_{3}$ gift/kvæntur
$\square_{4}$ skilin/n að borði og sæng
$\square$
$\square_{5}$ fráskilin/n
$\square$
$\square$ ekkja/ekkill

25. Hvernig var skólagöngu barnsins háttað?

(Merktu aðeins við hoesta skólastigið)

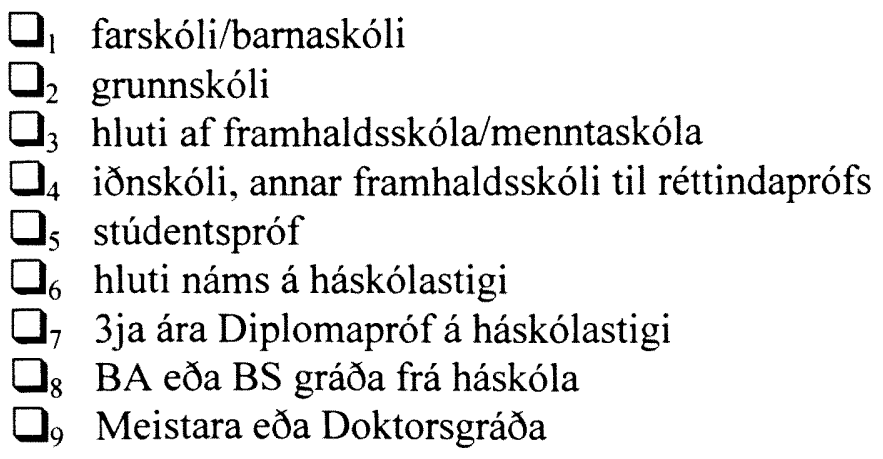


26. Hver af eftirfarandi fullyrơingum á best við um starf pessa barns píns?

(Merktu aðeins við einn reit.)

$\square_{1}$ á eftirlaunum, vinnur hlutastarf (minna en 40 stundir á viku)

$\square_{2}$ á eftirlaunum, í atvinnuleit

$\square_{3}$ á eftirlaunum hvorki í vinnu né í atvinnuleit

$\square_{4}$ í hlutastarfi (minna en 40 stundir á viku)

$\square_{5}$ í fullu starfi (40 stundir á viku eða meira)

$\square_{6}$ sér um heimilið (engin launuð vinna utan heimilis)

$\square_{7}$ atvinnulaus

$\square_{8}$ öryrki

$\square_{9}$ annað, $\Rightarrow$ Hvað?

27. Hvaða starf stundar dóttir/sonur pinn sem aðalstarf? (Ef á eftirlaunum, hvaða starf stundaði dóttir/sonur pinn fyrir starfslok?).

(Skýrðu frá starfsheitinu, til dœemis kokkur, ljósmóðir, sjómaður, afgreiðslumar. Ekki nafnið á vinnusta>num.)

28. Hversu langt frá pér býr petta barn pitt?

$\square_{1}$ hjá mér

$\square_{2}$ í göngufjarlægð frá mér

$\square_{3}$ minna en 30 mínútna akstur aðra leiðina

$\square_{4} 30$ mínútna til klukkustundar akstur aðra leiðina

$\square_{5}$ meira en einnar stundar akstur aðra leiðina

29. Hverjir veita pér aðstoð aðrir en umrædd(ur) sonur/dóttir bín? (Merktu við allt sem við á)

$\square_{1}$ enginn

$\square_{2}$ maki

$\square_{3}$ annað uppkomið barn

$\square_{4}$ aðrir ættingjar

$\square_{5}$ heimilishjálp

$\square_{6}$ heimahjúkrun

$\square_{7}$ vinir

$\square_{8}$ aðrir, $\quad \Rightarrow$ Hverjir? 
30. Hversu margra tíma aðstoð færð pú samanlagt á viku?

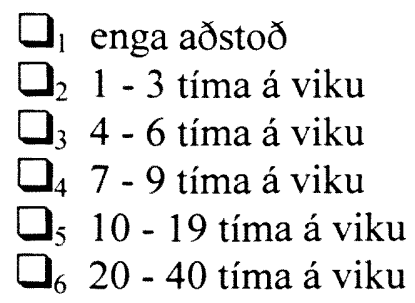

Búi dóttir bín/sonur pinn hér í grenndinni og pú álítur aơ hún/hann vilji taka pátt í könnuninni líka, vinsamlega skráou viðeigandi upplýsingar hér á eftir.

Nafn:

(skírnarnafn)

(föðurnafn)

Heimilisfang:

Póstnúmer: Bæjarfélag:

Símanúmer:

Pakka pér fyrir ad svara spurningunum hér ad framan.

Vinsamlega flettu yfir á næsta blad. 


\section{MENTAL STATUS SCREENING.}

Thank you for agreeing to complete this mental screening. Your participation is very important to the study. I am now going to ask you 10 questions and you may wonder why I am doing so. These questions are a part of the standard procedure that must be followed prior to completing the Respect for Autonomy Scale and the Paternalism Scale Questionnaires.

\section{The Mental Status Questionnaire}

1.) What is the name of this place?

2.) Where is this place located?

3.) What day is it?

4.) What is today's date?

5.) What year is it?

6.) How old are you?

7.) When were you born? (month)

8.) When were you born? (year)

9.) Who is the president of Iceland?

10.) Who was the president before this one? 


\section{Care of the elderly}

Elderly Parent Form.

Thank you for agreeing to answer questions regarding issues influencing caregiving for the elderly. Given the increased number of elderly people in our society, it is of great importance to pay attention to issues related to caregiving of the elderly. Confidentiality will be maintained, and information only published as group results.

For research purposes it is important to answer all questions, but your participation is strictly voluntary.

In this survey an elderly parent refers to a person 65 years old or older. To answer the questions you check in the box, circle a number or fill in the blank spaces that best indi cate your opinion. This questionnaire will take approximately 45 minutes to complete.

1. Questionnaire Id \#.:

2. Code number:

494

3. Are you... $\square_{1}$ male or $\square_{2}$ female?

4. How old are you? __ years old.

5. What is your present marital status?

$\square_{1}$ single

$\square_{2}$ living in a marriage like relationship

$\square_{3}$ married

$\square_{4}$ separated

$\square_{5}$ divorced

$\square_{6}$ widowed

6. Of what religion are you?

$\square_{1}$ I am Lutheran

$\square_{2}$ I have religious beliefs that are other than Lutheran

$\square_{3}$ I have no religious beliefs 
7. How far did you go in school? (Check your highest educational level).

$\square_{1}$ elementary school or less schooling

$\square_{2}$ junior high school

$\square_{3}$ part of senior high school/college

$\square_{4}$ trade or other education beyond high school

$\square_{5}$ high school diploma

$\square_{6}$ started but did not finish at university level

$\square_{7}$ three year Diploma at university level

$\square_{8}$ Bachelor's degree

$\square$ Master's or Doctoral degree

8. Which of the following statements best describes your occupational status? (Check one answer that best matches your situation)

$\square_{1}$ retired - working part time (less than 40 hours)

$\square_{2}$ retired, looking for work

$\square_{3}$ retired not working or looking for work

$\square_{4}$ working part-time (less than 40 hours)

$\square_{5}$ working full-time (40 hours weekly or more)

$\square_{6}$ housekeeping (no paid job outside the home)

$\square_{7}$ unemployed

$\square_{8}$ disabled

$\square_{9}$ other, specify

\section{What kind of work do you normally do?}

If retired what kind of work did you do before your retirement?

(Tell what the job is called, such as cook, welder, store manager, salesperson etc. Do not give the name of the place where you work or worked). 
14. What about your personal care? Do you manage without help?

$\square_{1}$ Yes

$\square_{2} \mathrm{No}=>$ If no, what do you need assistance with?

(Put a mark in front of all the item(s) with which you need help)

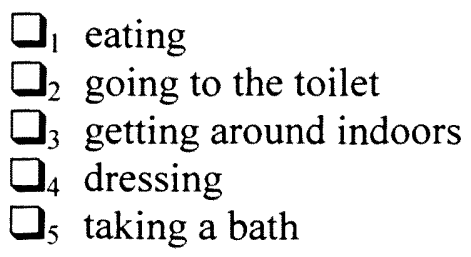

15. Do you use any helping aids to make things easier for you in your personal care?

$\square_{1}$ No

$\square_{2}$ Yes $\quad \Rightarrow \quad$ What aides do you use

16. In what type of accommodation do you live?

$\square_{1}$ own home or apartment

$\square_{2}$ rented house or apartment

$\square_{3}$ home of a child or other family member

$\square_{4}$ retirement village or apartment

$\square_{5}$ other; specify

17. Is your current type of accommodation your preferred choice?

$\square_{1}$ Yes

$\square_{2}$ No 
18. Do you live in an assisted living flat or in housing specially designed for the elderly?

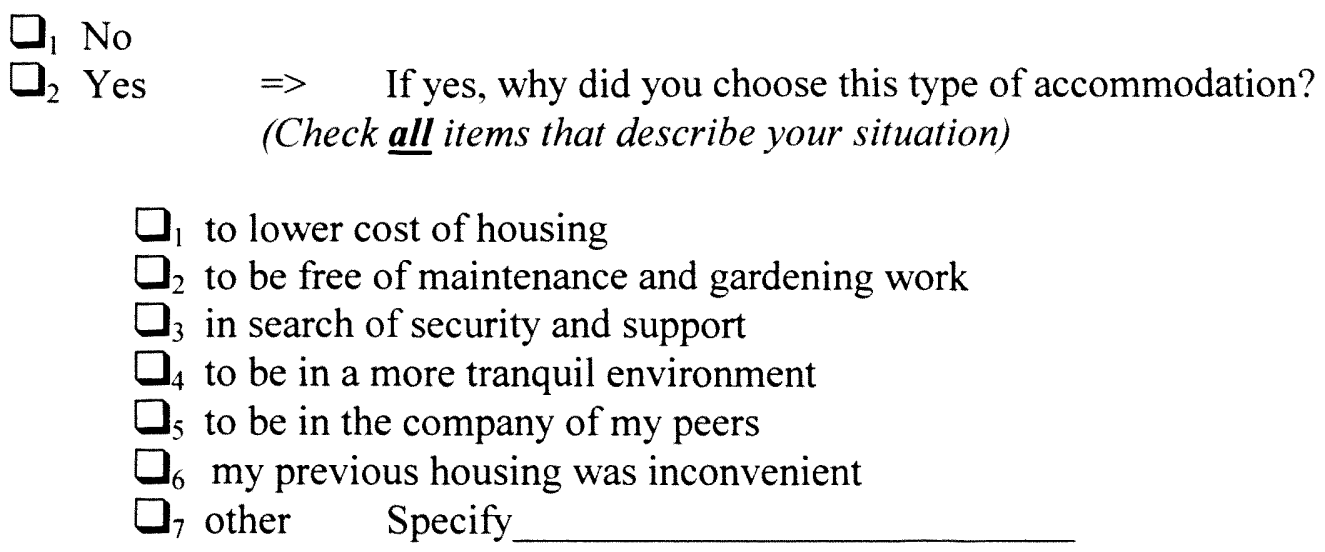

19. Would you prefer to live in your home out in the community to the day you die? (Provided you would get all necessary service and support from our society)
$\square_{1}$ Yes
$\square_{2}$ No

20. What does your personal income consist of? (Rank all sources that apply. The most important source as \# 1, next most important as \# 2, etc.).
$\square_{1}$ superannuation
$\square_{2}$ regular salary
$\square_{3}$ financial support from adult children
$\square$ low income support payment
$\square_{5}$ old age pension
$\square$ additional low income support payment
$\square$ disability pension
$\square_{8}$ other, Specify 


\section{How do you manage financially?}

Do you feel you have enough money for the little "luxuries" in life? (E.g. gifts, a visit to the hairdresser, tickets to the theater.)

$\square_{1}$ I can always afford the little "luxuries"

$\square_{2}$ I can often afford the little "luxuries"

$\square_{3}$ I can sometimes afford the little "luxuries"

$\square_{4}$ I can seldom afford the little "luxuries"

$\square_{5}$ I can never afford the little "luxuries"

The following questions are about the adult child whom you now depend on most for help (or would depend on most in the future).

22. What is the sex of your adult child:

$\square_{1}$ male or $\square_{2}$ female?

23. How old is this child?

The child is now years old.

\section{What is the marital status of this child?}

$\square$ single
$\square$ living in a marriage like relationship
$\square$ married
$\square$ separated
$\square$ divorced
$\square$. widowed




\section{How far did your child go in school?}

(Choose highest educational level).

$\square_{1}$ elementary school or less schooling

$\square_{2}$ junior high school

$\square_{3}$ part of senior high school/college

$\square_{4}$ trade or other education beyond high school

$\square_{5}$ high school diploma

$\square_{6}$ started but did not finish at university level

$\square_{7}$ three year Diploma at university level

$\square$ Bachelor's degree

$\square$ Master's or Doctoral degree

26. Is your child now working full-time, part-time, keeping house, or what? (Check only one answer that best describes her/his situation)

$\square_{1}$ retired - working part time (less than 40 hours)

$\square_{2}$ retired, looking for work

$\square_{3}$ retired not working or looking for work

$\square_{4}$ working part-time (less than 40 hours)

$\square_{5}$ working full-time (40 hours weekly or more)

$\square_{6}$ housekeeping (no paid job outside the home)

$\square_{7}$ unemployed

$\square_{8}$ disabled

$\square_{9}$ other, specify

27. What kind of work does your child normally do?

(If retired what kind of work did this child do before retirement?)

(Tell what the job is called, such as cook, welder, store manager, salesperson, and so on. Do not give the name of the place were your child works)

28. How far away from you does this child live?

$\square_{1}$ with me

$\square_{2}$ within walking distance

$\square_{3}$ less than 30 minutes drive one way

$\square_{4} 30$ minutes to one hours drive one way

$\square_{5}$ more than one hours drive one way 
29. Do you receive help from others apart from your daughter/son? (Check all items that apply).

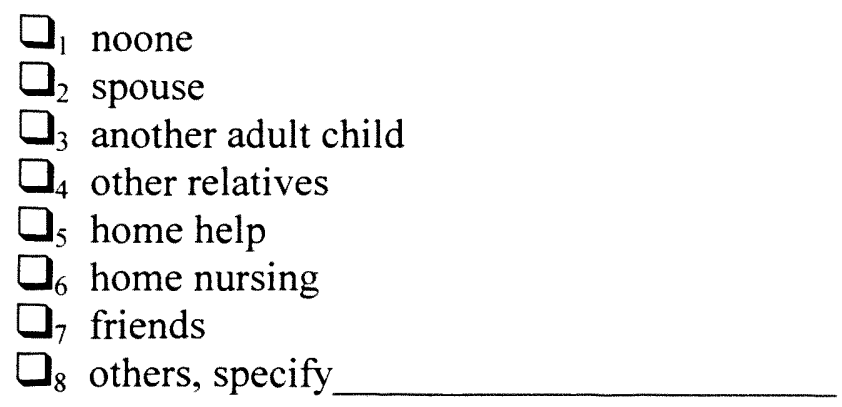

30. How many total hours of help do you get throughout the week?
$\square_{1}$ none
$\square_{2} 1-3$ hours per week
$\square_{3} 4$ - 6 hours per week
$\square_{4} 7$ - 9 hours per week
$\square_{5} 10-19$ hours
$\square_{6} 20-40$ hours

If your child lives locally and you think she/he may be willing to also complete a questionnaire please fill in the spaces below.

Name of child

(first name) (last name)

Address:

Zip code: City/town:

Telephone number:

Thank you for filling out this questionnaire.

Please turn to the next page. 


\title{
APPENDIX D
}

\section{Protocol of Instructions}

\author{
Icelandic Version
}

English Version 
Protocol of Instructions .

This questionnaire describes your beliefs about autonomy and paternalism in relation to the care of the elderly. By studying elderly people's perceptions on these issues we hope to increase the knowledge and understanding of the occupational therapy profession about the perceptions of elderly on these issues. This in turn will make therapists better able to support elderly in their independent living and in pursuing activities that are meaningful.

Read to the elderly:

1. This questionnaire takes about an hour to complete. Please answer all questions as incomplete questionnaires will not be used in this study.

2. The questions are repetitive because reliability and validity studies are also being conducted on the two instruments used in this study, the Respect for Autonomy Scale and the Paternalism Scale.

3. Please answer all questions as honestly as possible. If you cannot decide on an answer, choose the one that most closely represents your opinion.

4. There are no right or wrong answers in this study. Your honest responses are all that matters.

5. All answers will remain anonymous. Information will only be reported in groupresults.

6. Each questionnaire is quoded. This code is already on your questionnaires.

7. We appreciate your participation in this study. Thank you for taking the time to complete the questionnaire. 
pessi spurningalisti kannar skoðanir pínar á sjálfræði og forræði í tengslum við umönnun aldraðra. Með pví að kanna skoðanir eldra fólks á pessum málefnum viljum við reyna að auka við pekkingu og skilning iðjupjálfa á viðhorfum aldraðra gagnvart pessum málefnum. Við vonumst til að aukinn skilningur a málefninu geri iðjupjálfa færari að styðja eldra fólk til sjálfsbjargar og að sinna peim verkefnum sem eru pýðingarmikil fyrir hvern og einn.

Lesið fyrir hópinn:

1) $\quad$ bað tekur um pað bil klukkustund að svara listanum. Vinsamlega svaraðu öllum spurningum pví ekki er hægt að nota lista par sem vantar mörg svör.

2) Spurningar eru endurteknar pví verið er að meta áreiðanleika listana um viðringu fyrir sjálfræði og forræði í umönnun aldraðra.

3) Vinsamlega svaraðu spurningunum eins heiðarlega og hægt er. Ef pú átt erfitt með að ákveða pig, veldu pá pann kost sem best lýsir pinni sannfæringu.

4) bað eru engin rétt eða röng svör. Einlæg afstaða pín er pað sem skiptir máli.

5) Öll svör eru nafnlaus og niðurstöður verða aðeins birtar sem hópniðurstöður.

6) Hver spurningalisti er merktur númeri sem pegar hefur verið skrifað á listann,

7) Pátttaka pín er okkur mikils virði. Pakka pér fyrir að gefa pér tíma til að svara spurningalistanum. 


\section{APPENDIX E}

Advert and Flyer Text

Used to Advertize the Study 


\section{ADVERT AND FLYER TEXT THAT WAS USED TO ADVERTIZE THE SURVEY}

Your opinion counts!

We are three occupational therapists completing our master's degree with gerontology as are special interest area. Our research projects are on the attitudes and beliefs of various groups towards autonomy and paternalism in the care of the elderly. The purpose of the research is to assess people's attitudes and beliefs towards autonomy and paternalism in relation to care of the elderly as attitudes and beliefs affect behavior and therefore the caregiving relationship.

We hope that results from our study will assist the development of services for elders and their carers in the community.

Occupational therapists, older adults, and adult child carers are the three groups of people we wish to survey.

Are you or do you know an adult child who regularly assists an elderly parent?

Would you like to take part in the survey?

If the answer is yes please contact occupational therapist Valerie Harris on 5527605 / 5529133.

The questionnaire can be mailed to you or dropped off at your home with a pre paid reply envelope.

Are you a senior citizen 65 years or older, living in the community and have adult children?

Would you like to take part?

The survey will be conducted at the following places:

25 February Grandaveg 4.30pm

02 March Vitatorg $\quad 4 \mathrm{pm}$

12 March Aflagranda 10am

Coffee, tea and refreshments will be served!

If you are willing to take part in this survey but cannot make it on the above dates please contact Ingibjorg. S . Asgeirsdottir on 5611058 .

Many thanks. Valerie Harris and Ingibjörg S Ásgeirsdóttir. 